\title{
A QUESTÃO DA AQUISIÇÃO DE TERRAS POR ESTRANGEIROS NO BRASIL - um retorno aos dossiês
}

\section{LA CUESTIÓN DE LA ADQUISICIÓN DE TIERRAS POR EXTRANGEIROS EN EL BRASIL - el regreso a los dossiers}

\author{
THE QUESTION OF LANDS ACQUISITION BY FOREIGNERS \\ IN BRAZIL - a return to the dossiers
}

\author{
Ariovaldo Umbelino de Oliveira \\ Professor Titular Geografia Agrária - FFLCH - USP \\ arioliv@usp.br \\ Para Ursula, minha filha ${ }^{1}$ \\ "Abordar navios mercantes \\ Invadir, pilhar, tomar o que é nosso \\ Pirataria nas ondas do rádio \\ Havia alguma coisa errada com o rei. \\ Preparar a nossa invasão \\ E fazer justiça com as próprias mãos \\ Dinamitar um paiol de bobagens. ${ }^{2}$
}

Resumo: Este texto aborda a questão da aquisição de terras por estrangeiros nos últimos 50 anos no Brasil. Inicia-se pela análise do escândalo sobre a venda de terras para pessoas físicas e jurídicas estrangeiras na segunda metade da década de 1960, quando mais de 28 milhões de hectares foram transacionados, na maioria das vezes, de forma ilícita. Destaca o Relatório Velloso sobre este escândalo e a ações da ditadura militar para continuar garantindo a aquisição de terras pelos estrangeiros enquanto tentava mostrar um lado nacionalista à sociedade brasileira. Estes fatos são relatados como uma tragédia na história do país.

Também é discutida a atual questão sobre a aquisição de terras por estrangeiros sob a forma de uma farsa na história recente do Brasil. Primeiro devido à pouca expressão territorial que os estrangeiros possuem no país. Segundo porque a farsa, transformada em factóide, visou retirar do centro do debate político a questão da reforma agrária e tentar encobrir a opção pela contra-reforma agrária no segundo mandato do governo Luiz Inácio Lula da Silva e depois com Dilma Rousseff. E, por fim, discutem-se as questões sobre a terra no capitalismo rentista mundializado no Brasil.

Palavras-chave: Terras de Estrangeiros, Reforma Agrária, Contra-reforma agrária, Grilagem de Terras, Capitalismo Rentista.

\footnotetext{
${ }^{1}$ Dois motivos levam-me a dedicar esse texto para Ursula, minha filha. Primeiro, porque comprei para ela um dia na década de 80, o LP do RPM (que temos até hoje) com suas músicas irreverentes, entre elas Radio Pirata. Inclusive, ela só pôde ouvir o lado "B", porque o lado "A" vinha riscado pela censura da ditadura militar, pois, lá estavam as músicas proibidas: Revoluções por minuto e Alvorada voraz. A capa do LP trazia escrito: "Proibida a radiodifusão e execução pública da música: Revoluções por minuto." Segundo, porque me ajudou a resolver o uso das noções em língua inglesa sobre o tema do texto.

2 RICARDO, P. \& SCHIAVON: 1984, Rádio Pirata, RPM, LP "RPM - Radio Pirata ao vivo", Epic/CBS, Rio de Janeiro.
} 
Resumen: Este trabajo aborda la cuestión de la adquisición de tierras por extranjeros en los últimos 50 años en Brasil. Comienza examinando el escándalo por la venda de tierras a particulares y empresas extranjeras en la segunda mitad de los años 1960, cuando más de 28 millones de hectáreas fueron negociados en la mayoría de los casos de manera ilegal. Destaca el Informe Velloso sobre el escándalo y las acciones de la dictadura militar para seguir garantizando la adquisición de tierras por extranjeros mientras trató de mostrar un lado nacionalista a la sociedad brasileña. Estos hechos se presentan como una tragedia en la historia del país.

También se analiza la actual cuestión de la adquisición de tierras por extranjeros en la forma de una farsa en la historia reciente de Brasil. En primer lugar, por la poca expresión territorial que los extranjeros tienen en el país. En segundo lugar, porque la farsa es convertida en factoide, destinado a retirar del centro del debate político el tema de la reforma agraria y tratar de encubrir la opción por la contrarreforma agraria en el segundo mandato del gobierno Luiz Inácio Lula da Silva y de Dilma Rousseff. Finalmente, se discuten los temas de la tierra en el capitalismo rentista globalizado, en el Brasil.

Palabras clave: tierras extranjeras, la reforma agraria, contrarreforma agraria, el acaparamiento de tierras, capitalismo rentista.

\begin{abstract}
This paper addresses the issue of land acquisition by foreigners in the last 50 years in Brazil. It begins by examining the scandal over the sale of lands to foreign individuals and companies in the second half of the 1960's, when more than 28 million hectares were transacted, in most cases, illegally. The Velloso's Report highlights the scandal and actions of the military dictatorship to ensuring the acquisition of lands by foreigners. Meanwhile, the government tried to show a nationalist side to Brazilian society. These facts are shown as a tragedy in Brazilian history.

It is also discussed the current question of lands acquisition by foreigners as a farce in Brazilian recent history. Firstly, because of the little territorial expression those foreigners possess in this country. Second, the farce turned into a phony news item and aimed to remove the issue of agrarian reform of the center of political debate, trying to cover up the option of the agrarian contra-reform in the Luiz Inácio Lula da Silva's second term and then Dilma Rousseff. Finally, we discuss the issues of land in the globalized rent seeking capitalism in Brazil.
\end{abstract}

Keywords: lands of foreigners, agrarian reform, agrarian contra-reform, land grabbing, rent seeking capitalism

\title{
Introdução
}

Marx iniciou uma de suas importantes obras no Século XIX, com o seguinte pensamento "Hegel observa em uma de suas obras que todos os fatos e personagens de grande importância na história do mundo ocorrem, por assim dizer, duas vezes. E esqueceu-se de acrescentar: a primeira vez como tragédia, a segunda como farsa." (MARX, 2011: 176) Este é também, o mote principal deste texto. No Brasil, há vários temas que aparecem ao longo de sua história contemporânea como verdadeiros "factóides", como eles são denominados pela mídia. Eles vão e voltam aos noticiários 
cotidianamente, criando a ilusão de que são, de fato, verdadeiros, perigosos ou indesejáveis. Eles não o são, porém são trabalhados ideologicamente para parecerem que são verdades incontestes que estão próximas de se realizarem. Muitas vezes, tratamse de típicas ideologias que são veiculadas para criarem um embate abstrato entre posições políticas nacionalistas ou falsamente nacionalistas e aquelas internacionalistas, entreguistas ou não. A principal delas é sobre a internacionalização da Amazônia.

Desde o início do Século XX, as classes dominantes, particularmente os ruralistas, e os militares "deliciam-se" e "deliciam" parte da sociedade brasileira com esse debate. Muitos livros e textos já foram escritos, embates realizados nas universidades e fora delas. Ou seja, consumiram-se tempo e esforços para discutir uma questão que na realidade, de fato, nunca existiu. Certamente, muitos se lembraram da ideologia dos "Grandes Lagos Amazônicos" do Instituto Hudson do Mr. Hermann Kahn, na época da ditadura militar. Naqueles duros anos, isso levou, inclusive, à criação da CNDDA (Comissão Nacional de Defesa e pelo Desenvolvimento da Amazônia) liderada pelo geógrafo Orlando Valverde e muitos militares nacionalistas da reserva. $\mathrm{Na}$ realidade, jamais o governo militar de então teve a intenção de implantar aquele projeto, mas, deixou-o rolar na mídia como se de fato ele fosse acontecer. Foi uma comoção nacional, debates, textos, jornais, revistas, muito papel e esforços consumidos, mas, enquanto isso, a ditadura implantou o PIN - Programa de Integração Nacional, abrindo a Amazônia aos interesses do capital nacional e mundial. O Projeto Jari do multimilionário Daniel K. Ludwing foi implantado no vale do rio Jari na divisa do Pará e do Amapá com seus mais de 4,6 milhões de hectares divididos em dois imóveis registrados no Cadastro do INCRA como Jari Florestal e Agropecuária Ltda com 2.918.829 hectares e Cia Florestal Monte Dourado com 1.682.227 hectares. Em Almerim no Pará, o National Bulk Carriers obtinha do governo militar 1.250.000 hectares e a Georgia Pacific conseguia 400.000 hectares em Portel e Melgaço também no Pará. (OLIVEIRA, 1987; OLIVEIRA 1988, OLIVEIRA, 1997) Inclusive, a rede Globo veiculou na época o programa "Amaral Neto, o repórter", que de forma épica mostrava os feitos da ditadura na Amazônia como se fizessem a defesa da pátria. Dessa forma, enquanto os governos militares e a mídia informavam ao país que defendiam a Amazônia contra os interesses externos, internacionalizaram integralmente a economia 
brasileira e, logo, a Amazônia, sem precisar entregar um pedaço do país, como diria Armando Corrêa da Silva (1985), a um outro país imperialista, qualquer que fosse ele. ${ }^{3}$

Agora, em pleno Século XXI, o governo do Partido dos Trabalhadores - PT, resolveu reinventar "factóides" para divertirem a esquerda e, principalmente, os movimentos sócio-territoriais e sindicais. A meu juízo, dois são os novos "factóides": a mudança dos índices de produtividades para definir a improdutividade ou não dos imóveis rurais pelo INCRA, e, a última e grande "jogada ideológica", ou seja, à aquisição de terras por estrangeiros no Brasil. Sobre o primeiro, penso que não é necessário lembrar, sobretudo, os companheiros e, de uns tempos para cá, os "novos camaradas", que jamais o governo vai alterar os índices de produtividades, mas, sempre nas reuniões com os movimentos sociais e sindicais dirão que vão alterá-los. Aliás, essa "história da carochinha" já voltou outra vez no governo atual do PT, sob a benção da "ideologia do cientificismo" da Embrapa. Mas, o segundo "factóide", foi retirado do baú em uma ação conjunta MDA/INCRA, exatamente, por quem, na época tinha a obrigação legal e funcional de fazer cumprir a legislação em vigor e encaminhar à justiça aqueles que não há cumpriam, ou seja, o ex-presidente do INCRA Rolf Hackbart. Foi ele próprio que se incumbiu de noticiar ao país o "novo perigo internacional" aos pseudos e aos verdadeiros nacionalistas de última hora: à aquisição de terras por estrangeiros no Brasil. Curiosamente, é a segunda vez que essa notícia vem a público, pois, a primeira vez foi em plena ditadura militar do final da década de 60, quando de fato, os órgãos públicos e os grileiros de terras públicas estavam vendendo a grupos estrangeiros, terras brasileiras em um total apurado de mais de 28 milhões de hectares, e, a maioria delas na Amazônia. É exatamente sobre essas duas histórias, uma verdadeira e a outra fabricada que esse texto tratará, pois, a memória neste país é sempre, propositalmente esquecida.

\section{O escândalo da aquisição de terras por estrangeiros nos anos 60 do Século $X X$, pela ditadura militar - a verdade.}

Não é demais continuar lembrando que o final da década de 50 e início da década de 60, foram marcados pelo processo de organização/reivindicação dos camponeses, sobretudo nordestinos, no país. Esse processo gerou a criação das Ligas

\footnotetext{
${ }^{3}$ Nos livros "Amazônia: monopólio, expropriação e conflitos", 1987, "Integrar para não entregar Políticas Públicas e Amazônia", 1988, e na tese de livre docência "A Amazônia norte-matogrossense: grilagem, corrupção e violência", 1997, tratei exaustivamente dessa questão.
} 
Camponesas, cuja luta pela terra e contra a exploração do trabalho no campo marcou de forma exemplar sua história. Como consequência da ampliação da luta pelas Ligas Camponesas, o governo João Goulart criou a SUPRA - Superintendência da Política Agrária, órgão do governo federal responsável pela implantação de uma política de reforma agrária. Inclusive, como escrevi, (OLIVEIRA, 1997: 67/8) antes de sua deposição pelos militares, João Goulart havia encaminhado ao Congresso um projeto de lei que alterava o artigo da Constituição que previa indenização prévia em dinheiro para as desapropriações, passando a mesma a ser feita em títulos da dívida pública. O projeto previa também, a desapropriação das terras situadas às margens das rodovias e dos açudes públicos federais, ou seja, o governo procurava orientar-se pelo princípio de que "o uso da propriedade está condicionado ao bem-estar social, não sendo a ninguém lícito manter a terra improdutiva por força do direito de propriedade".(BANDEIRA, 1977: 164/5)

Como se sabe, o golpe militar de 1964 abortou o projeto de reforma agrária de João Goulart, caçou literalmente as lideranças que militavam nas Ligas Camponesas e reprimiu o movimento. Mas, contraditoriamente, foi o Marechal Castelo Branco que assinou a lei que criou o Estatuto da Terra - Lei n. 4.504, de 30/11/64. Como também escrevi, foi o próprio Ministro do Planejamento do então governo militar, Roberto Campos, quem garantira aos congressistas latifundiários que a lei era para ser aprovada, mas não para ser colocada em prática. A história dos 20 anos de governos militares mostrou que tudo não passou de mais uma farsa histórica, pois apenas em 1985, é que o governo federal da "Nova República" de Sarney, elaborou o $1^{\circ}$ Plano Nacional da Reforma Agrária - instrumento definidor da política de implementação da reforma agrária. (OLIVEIRA, 1997: 68) Entretanto, com a lei do Estatuto da Terra, o governo militar extinguiu a SUPRA e criou dois órgãos para implantar a reforma agrária que não foi feita: o Instituto Brasileiro de Reforma Agrária (IBRA) e Instituto Nacional de Desenvolvimento Agrário (INDA).

\subsection{A CPI da aquisição de terras por estrangeiros e o Relatório Velloso}

Entre 1964 e 1970, o IBRA e o INDA viveram um processo intenso de corrupção, grilagens e venda de terras para estrangeiros, que terminou na constituição, pelo Congresso Nacional, em 1968, de uma Comissão Parlamentar de Inquérito para apurar as denúncias veiculadas pela imprensa. Da CPI nasceu o relatório - Relatório 
Velloso, e a comprovação do envolvimento de inúmeros brasileiros particulares e funcionários do IBRA e de cartórios públicos, na grande falcatrua da aquisição de terras por estrangeiros, sobretudo na Amazônia:

"No momento ainda é muito difícil precisar-se, com exatidão, as áreas mais atingidas pelo problema que está sendo estudado. Todos os dados obtidos até agora devem ser considerados apenas como dados parciais e muito tempo ainda se necessitará de trabalho paciente e meticuloso, para que se possa ter uma idéia precisa da profundidade do problema. $\mathrm{O}$ trabalho se torna mais difícil pela evolução constante dos fatos, pois muitas áreas em nome de brasileiros já estão com negociações entabuladas para serem transferidas para propriedade de grupos estrangeiros e, em muitos casos, áreas já compradas por grupos estrangeiros ainda são mantidas em nome de seus antigos proprietários e posseiros, com o evidente propósito de evitar a constatação de seus verdadeiros donos. Ainda são poucos, no momento, os dados obtidos, principalmente os relativos aos estados de Mato Grosso e Acre e territórios de Rondônia, Roraima e Amapá, mas, apesar disto, as informações já obtidas formam um quadro geral que preocupa bastante. Assim podemos apresentar, ressaltando uma vez mais ser apenas um levantamento parcial, as seguintes áreas já ocupadas ou em vias de ocupação por grupos estrangeiros:

a) Estado de Goiás: em São João da Aliança um grupo belga adquiriu 36.014 hectares; em Araguaína um proprietário não-identificado possui 23.368 hectares; em Tocantinópolis, o grupo Universal Overseas Holding diz ter comprado 504.700 hectares e a Cia. Agropastoril Água Azul outros 4.459 hectares; em Filadélfia, Chan Tun Jan adquiriu 48.400 hectares; em Uruaçu, John Mauger possui 113.105 hectares; em Piacá, Henri Fuller comprou 38.720 hectares, a World Land Co. outros 72.600 hectares e outro grupo não-identificado 24.200 hectares; em Peixe, John Mauger adquiriu área ainda ignorada; o Mr. Stanley Amos Selig comprou 3.918 hectares em Paraíso, outros 24.648 hectares em Niquelândia, em Paranã 12.100 hectares e em Ponte Alta do Norte 1.305.000 hectares. Neste estado, no momento, já se pode apresentar 3,5\% de seu território em mãos de pessoas, ou grupos estrangeiros, devendo-se ressaltar que, no município de Ponte Alta do Norte, toda a sua área, 1.305.000 hectares, está em poder de Stanley Amos Selig, que vendeu nos EUA um total de 1.390.438 hectares em lotes nesse município, maior portanto que a própria área do mesmo.

b) - Estado do Maranhão: o Sr. João Inácio adquiriu em Monção 534.336 hectares, em Turiaçu 406.074 hectares, em Carutapera duas áreas sendo uma de 696.900 hectares e outra de 150.000 hectares. Neste estado ainda não foi conseguida nenhuma apreensão de documentos que comprovassem a venda destas áreas a estrangeiros, apesar do proprietário, João Inácio, grileiro já anteriormente mencionado, ser um dos principais intermediários em grandes vendas a grupos de outras nações.

c) - Estado do Amazonas: lá também, o Sr. João Inácio, diz possuir em Barcelos 418.280 hectares, em Ilha Grande 77.440 hectares, em Nhamundá 96.800 hectares, em Borba 239.040 hectares, em Manaus 
778.800 hectares; em Novo Aripuanã 195.570 hectares, em Maués 29.040 hectares e em Itacoatiara 4.530 hectares. É conveniente ser ressaltado que pelo menos as terras em poder de João Inácio, nos municípios de Borba e Manaus, foram adquiridas do Estado como terras devolutas, em flagrante choque com a Constituição do Brasil, pois as referidas áreas ultrapassam 1.000 .000 hectares.

d) - Estado do Pará: o Sr. João Inácio diz ter adquirido em Altamira 1.015.860 hectares, em São Félix 3.602.072 hectares, em Vizeu 390.040 hectares, em Paragominas 191.164 hectares, e em Conceição do Araguaia outros 257.004 hectares. Ainda nesse estado em Paragominas, John Davies afirma ter comprado 52.272 hectares; em Almerim, o grupo National Bulk Carriers adquiriu 1.250.000 hectares; em Tomé-Açu, a Jamic comprou 25.800 hectares; em Portel e Melgaço a Georgia Pacific tem 400.000 hectares; em Melgaço, Robert Richard Morrow possui 40.658 hectares; em Portel, Curralinho, Breves, Anapu, Anajás, e em Bagre, Robin Hollie Mac Glow teria adquirido 400.000 hectares; em Açará, Jacob Klauss tem área ignorada; em Itaituba, Arruda Pinto diz ter 300.000 hectares; em Curralinho, Gork Stinson tem 8.344 hectares, Ed Kay Properties tem 1.659 hectares e Missio Bay outros 632 hectares; e em Portel, Hartzel Vinhard tem 576 hectares. Deixa de ser incluída a relação de propriedades negociadas pelo grupo Nadyr Helou que no momento são objeto de investigações. Também é conveniente ressaltar que a maioria das terras em poder do grupo João Inácio, que perfazem um total de mais de 5.000.000 hectares, muitas delas foram adquiridas por requisição ao Estado, como terras devolutas, o que fere frontalmente o disposto na Constituição do Brasil.

e) - Estado da Bahia: neste estado, como já exposto anteriormente, as regiões atingidas são os municípios de $\operatorname{Cocos,~Correntina,~São~}$ Desidério, Bom Jesus da Lapa e Formosa do Rio Preto. Perfazem estas terras um total de 5.600.000 hectares, distribuídas em 53 fazendas, sendo portanto a área atingida superior a $10 \%$ da área do estado.

f) - Estado de Mato Grosso: apesar das poucas informações obtidas até agora, devem ser grandes as áreas em poder de 50 grupos estrangeiros, já que possivelmente nesse estado, na década de 50, iniciou-se o processo de vendas de vulto a grupos externos. As poucas informações relacionadas neste relatório já dão um total superior a 2.000.000 hectares, sabendo-se que muitos outros não estão ainda relacionados, inclusive o já citado Stanley Amos Selig, que também possui terras no município mato-grossense de Barra do Garças.

g) - Território de Roraima: o Mr. James Bryan Choate tem 232.915 hectares: James Wilmer Crews no Rio Tacutu possui área ignorada e João Inácio no Pico da Neblina, também teria área ignorada.

h) - Outros dados: é grande o volume de informações existentes nos diversos depoimentos prestados, bem como obtidas por esta CPI e pela Comissão de Investigação do Ministério da Justiça, necessitando ainda serem devidamente apuradas para posterior confirmação. Podese acrescentar a estes dados a existência da venda de grandes áreas de terras no município de Aveiro, estado do Pará, território de Rondônia, na região de exploração de cassiterita e território do Amapá, principalmente na região da Boca do Amazonas. No momento, já 
existe apurada a venda de cerca de 20 milhões de hectares a pessoas ou grupos estrangeiros, distribuídos pelos diversos estados e municípios mencionados e que, como facilmente se poderá constatar, excetuando-se as terras alienadas no estado da Bahia, as demais, em quase sua totalidade, encontram-se dentro da Região Amazônica." (GARRIDO FILHA, 1980: 84/7)

Conforme pode-se observar pelo que foi possível apurar pela CPI, mais de 20 milhões de hectares de terras brasileiras, a maioria na Amazônia (mais de 15 milhões de hectares), estavam transacionados com grupos estrangeiros. Para ser mais realista, uma superfície superior a ocupada por muitos estados brasileiros, estava em poder de estrangeiros.

Esse processo lesivo aos interesses nacionais, pôde acontecer em função do uso de expedientes criminosos, que por si só poderiam vir a convencer a justiça do país à anulação das concessões. Isto pode ser observado pelas conclusões do Relatório Velloso na averiguação dos métodos e processos de aquisição de terras:

"É, uma constante, na aquisição de terras por estrangeiros, a presença do elemento nacional como intermediário. Talvez uma das poucas exceções seja o Sr. Robin Hollic Mac Glow, cidadão americano, que intensamente se dedica, no Pará, à atividade de compra de vastas áreas para posteriormente vendê-las a compatriotas seus, com grande margem de lucro. Pelas observações podemos agrupar os processos de aquisição de terras em três tipos diferentes:

a) - Compra a antigos proprietários ou posseiros: neste processo um intermediário entra em contato com o proprietário ou posseiro de determinado lugar, de interesse de um grupo, e propõe a compra do mesmo. De um modo geral, o proprietário ou posseiro, sem recursos para explorar suas terras, com dificuldades em obter financiamentos e premido pelos impostos, principalmente os do IBRA, aceita com prazer a proposta, sempre feita com dinheiro à vista. Este processo é repetido com todos os elementos da zona visada, que assim passa a ser propriedade de um grupo estrangeiro, apesar de muitas vezes, enquanto interessar, as terras ainda serem mantidas em nome dos antigos proprietários, o que dificulta em muito o levantamento de áreas do território nacional em mão de estrangeiros.

b) - Requisição de terras devolutas aos governos estaduais: neste processo o elemento nacional intermediário, geralmente com a conivência de funcionários dos Departamentos de Terras estaduais, requer em nome de pessoas, verdadeiras ou fictícias, individualmente, um grande número de lotes, cada um dentro das limitações constitucionais de modo a cobrir toda a zona cobiçada. Após a obtenção dos títulos definitivos, de acordo com o interesse, ou não, do comprador, os títulos individuais passam, por meio de compra simulada, para o nome da pessoa ou grupo, nacional ou estrangeiro, interessado na compra daquela região. Com isto é que se explica como vastas regiões de terras devolutas estaduais, apesar das limitações 
constitucionais, passam de um momento para outro a se constituir em enormes latifúndios em mãos de pessoas ou grupos nacionais ou estrangeiros. Este processo foi usado em larga escala no estado de Mato Grosso, na década de 50, e foi usado, conforme demonstrado em informações colhidas por esta CPI, nos estados do Pará e Amazonas, o que explica grandes extensões desses estados em poder do grileiro João Inácio, requeridas como terras devolutas.

c) - 'Grilagem': por intermédio deste processo todos os tipos de fraude são aplicados, desde escrituras falsificadas, aparentando documentos antigos, até títulos definitivos de compra de terras devolutas, também falsos. Por intermédio desse processo o cidadão norte-americano Stanley Amos Selig conseguiu a posse de todo o município de Ponte Alta do Norte, em Goiás, e, por intermédio desse mesmo processo o seu intermediário, João Inácio, já tinha sob seu controle vastas extensões, em toda a Amazônia, prontas para serem transferidas para grupos nacionais ou estrangeiros. Dentro da 'grilagem', verifica-se que, com o aproveitamento do que dispõe o Código Civil Brasileiro, que permite em seu artigo 134, parágrafo $2^{\circ}$, o uso da escritura particular para transações até $\mathrm{NCr} \$ 10,00$, sistematicamente dão esse valor simbólico a todas as transações feitas, fugindo assim da escritura pública, e assim, de um modo geral, começando os 'grilos', isto é, através de um instrumento particular de compra e venda. É uma constante nas operações desse tipo a venda de terras, sempre pelo total de $\mathrm{NCr} \$ 10,00$, e sempre por intermédio de um instrumento particular, que posteriormente é registrado em um cartório, já mancomunado para isto. Nesse processo de 'grilagem', conforme verificado por esta CPI em sua viagem a Porto Nacional, até o roubo de documentos antigos de velhas igrejas foi feito, sendo o papel em branco de livros de registros paroquiais roubado para ser utilizado na confecção de escrituras, em tudo semelhantes à feitas no século passado. A técnica usada na fraude e no crime, por maus brasileiros, pode ser considerada quase perfeita e valendo-se dela é que muitos grupos estrangeiros estão hoje de posse de vastas extensões do território brasileiro." (GARRIDO FILHA, 1980: 87/9) (grifo meu)

Agora, passados muitos anos, pode-se concluir que não se tratava de uma ação de "maus brasileiros" como o relatório demonstrou, mas sim, de uma bem montada estratégia de permitir aos grupos internacionais e nacionais o acesso às riquezas naturais da região amazônica e do Brasil em geral. Essa estratégia fazia parte da política posta em prática pelos governos militares que passaram a comandar e planejar este processo A prova inequívoca deste, aparece evidenciada na estratégia que os grandes grupos econômicos nacionais e internacionais passaram a utilizar no Brasil da ditadura militar para conseguir vantagens e favores: incluir em cargos de suas diretorias altas patentes militares. Foi o caso de um dos maiores proprietários estrangeiros da Amazônia Projeto Jari - que teve o Major Heitor de Aquino Ferreira, que tantos cargos ocupou nos 
vários governos militares, como apontou SAUTCHUK et alli, em seu livro "Projeto Jari - A invasão americana", como diretor da empresa.

Assim, os governos militares procuravam encobrir a real intenção de seus planos com relação à internacionalização da economia brasileira. Por trás de uma falsa bandeira "nacionalista", foram entregando os recursos naturais do país, e a Amazônia era parte substantiva desse processo. (OLIVEIRA, 1997:69/73)

\subsection{O envolvimento do governo militar e a repressão}

Como também escrevi (OLIVEIRA, 1988), o jornal Folha de São Paulo, forneceu os indícios, para se entender este processo de envolvimento de órgãos e pessoas do governo militar nestes casos:

"A questão da aquisição de terras por estrangeiros, principalmente norte-americanos, muito divulgada e debatida na imprensa, no ano passado, será melhor compreendida através da amarração de uma série de fatos esparsos, mas que estão interligados por um fio comumente invisível. Tudo se resume no seguinte. Grupos imobiliários norteamericanos, juntamente com sócios e testas-de-ferro brasileiros, adquiriram ou grilaram, isto é, legalizaram com título falso, imensas extensões de terras no Brasil, principalmente nos estados de Goiás, Pará e Amazonas. O grupo que se tornou mais conhecido pelo noticiário dos jornais e pela desenvoltura do seu responsável é o de Stanley Amos Selig, e de Ben Selig, associados ao húngaro Arpad Szuecs e ao brasileiro João Inácio ... O Juiz Anésio Rocha Brito, de Porto Nacional, alertou a polícia para o fato de João Inácio ter colocado um elemento de sua confiança no cartório do $1^{\circ}$ Ofício Civil da cidade, em conivência com a escrivã Maria Teresa Barreira Cavalcante. Esse elemento, o jovem Wilson Dias da Rocha, foi detido em Campinas, em novembro do ano passado, juntamente com um cofre contendo toda a documentação de João Inácio, que trabalhava, também, para vários outros grupos norte-americanos. A polícia federal buscava João Inácio, mas este conseguiu evadir-se. Até hoje, a polícia nada divulgou a respeito da documentação apreendida, que envolve mapas assinalados por códigos secretos, e até certidões de nascimento e casamento assinadas em branco. Outro cartório implicado nas negociações é o do $5^{\circ}$ Oficio de Goiânia. Até o momento, foram anotados os seguintes nomes de firmas que promovem, irregularmente, a venda de terras no exterior: Selig Brothers Real Estate Company, Colonizadora Norte-Mato Grosso Ltda., Comercial United Ltda., Imobiliária Ney Mendes Fonseca, Investment Corporation of America Inc., Imobiliária e Colonizadora Agrícola de Brasília Ltda., Colonização Terras 'Alvorada,' São Paulo-Paraná Ltda., Colonizadora Noroeste Mato-Grossense, Imobiliária, Santa Cruz Ltda., Jack W. Nunnally e Bahia Stampede."(FOLHA DE SÃO PAULO - SUPLEMENTO ESPECIAL, 05/05/1968:63/4) 
A matéria do jornal, em seguida, apontou e alinhavou uma série de fatos de modo a confirmar o envolvimento governamental com o acontecido, pois a área mais procurada pelos norte-americanos era exatamente aquela que fora objeto de levantamentos efetuados, em 1964, por uma equipe do "Bureau of Reclamation", órgão do Departamento do Interior dos EUA, por solicitação da USAID e da CIVAT Comissão Interestadual dos Vales do Araguaia e Tocantins. Ou seja, os norteamericanos contavam com material aerofotogramétrico para decidirem a escolha da área a ser ocupada, documentos estes existentes no seio dos órgãos de segurança nacional, secretos para os brasileiros, mas abertos para todos os norte-americanos nos Estados Unidos.

Um outro aspecto grave dessa questão, refere-se à utilização de fotografias aéreas e levantamentos aerofotogramétricos realizados pela USAF- a Força Aérea dos EUA - de acordo com permissão dada pelo marechal Castelo Branco. Afirmava-se que tanto os planejadores hudsonianos, como os grileiros do então Norte de Goiás, atual estado do Tocantins, e de outros pontos da Amazônia, tiveram acesso àqueles documentos.

Além da permissão para os levantamentos, os norte-americanos contavam com os aviões U-2 e com os satélites artificiais. Inclusive, fotografias da USAF foram encontradas na documentação apreendida na casa do grileiro João Inácio, sócio de Stanley Selig e de Arpad Szuecs, em Campinas.

Como pode se verificar, começava aparecer parte da real intenção do governo militar instalado em 1964, pois, vinha a público a autorização fornecida pelo Marechal Castelo Branco à USAF para proceder ao levantamento aerofotogramétrico do país em 1965. O comando deste levantamento coube ao Major Martins Stewart que, baseado em São Paulo, contava com 10 aviões Lockheed Hercules e 60 aviadores. (MOREL, 1984:70)

Aliás, o próprio Relatório Velloso deixou registrado o envolvimento no episódio do então embaixador brasileiro em Washington, Vasco Leitão da Cunha, envolvido na denúncia feita pelo Sr. Mac Glow, da Georgia Pacific, outro latifúndio na Amazônia brasileira (400.000 ha):

"Segundo o Sr. Mac Glow, em seu depoimento prestado em Belém perante a Comissão de Investigação do Ministério da Justiça, e na presença do relator desta CPI, esta diferença foi constatada em virtude 
de ter a Georgia Pacific, em fins de 1966 ou começo de 1967, obtido, por intermédio do embaixador do Brasil em Washington, cópias do levantamento aerofotogramétrico feito pela Força Aérea norteamericana, em cumprimento ao acordo entre o Brasil e os Estados Unidos ... De acordo com informações colhidas junto ao Serviço Geográfico do Exército, que controla este tipo de atividades no território nacional, a região foi levantada pelo Serviço Aerofotogramétrico da Cruzeiro do Sul, por contrato com o Departamento Nacional de Portos e Vias Navegáveis, tendo a Companhia de Madeiras e Laminados (Georgia Pacific) comprado uma coleção, num total de 532 fotos."(GARRIDO FILHA, 1980:80/1)

Dessa forma, o Congresso Nacional, no ano de 1968, foi sacudido com grande número de denúncias, e o governo militar, através de mais um ato de força (Ato Institucional $\mathrm{n}^{\mathrm{o}} 5$ ), no final do ano (13/12/68), fechou-o por tempo indeterminado, suspendeu garantias constitucionais e individuais, efetuou cassações, etc. O "bode expiatório" para o endurecimento do regime foi, nada mais nada menos, do que o autor do pedido da CPI para apurar à aquisição de terras por estrangeiros, o deputado federal Márcio Moreira Alves. Começava, neste episódio uma das piores fases da história do Brasil, debaixo de regimes militares violentamente repressivos. (OLIVEIRA, 1997:79/81)

\section{A legislação federal sobre à aquisição de terras por estrangeiros}

\subsection{A "legalização" do escândalo pelos governos militares}

Como também escrevi, (OLIVEIRA, 1997) o resultado das investigações sobre as irregularidades apontadas pelo Relatório Velloso não foram adiante; ao contrário, produziu-se novamente a farsa de fazer a lei para moralizar, deixando porém, a brecha para ratificar as irregularidades, tornando-as "legalizadas", ou, na pior das hipóteses, legalizáveis. O processo desfechado em termos legais, de fato, dura até hoje. O que significa dizer que a legislação abriu possibilidades para, mesmo nos dias atuais, grandes latifúndios serem transferidos para as mãos de grupos internacionais. Veja-se o percurso e a trajetória dessas leis.

Em 3 de junho de 1968, veio a público o parecer do Relatório Velloso. O deputado federal, Major Haroldo Velloso, eleito pela Arena, representava o controle militar na apuração dos acontecimentos. Sua posição política diante dos novos rumos da economia brasileira, baseava-se no fato de que "o capital estrangeiro era benéfico ao desenvolvimento nacional"; entretanto, seu relatório teve que revelar ao país o escândalo da venda de mais de 20 milhões de hectares de terras a estrangeiros, a maioria 
delas na Amazônia, "a ponto de identificar uma suposta tentativa de constituição de um cordão de propriedades, isolando a região do resto do país". (SAUTCHUK ett alli, 1979:78)

No segundo semestre de 1968, o Congresso Nacional negou a autorização para que o Supremo Tribunal Federal processasse o deputado federal Márcio Moreira Alves a razão evocada foi "ofensa grave à honra e dignidade das Forças Armadas". Na realidade, o deputado havia pedido, em discurso de cinco minutos no Congresso e que havia passado desapercebido, inclusive, pela imprensa, o boicote da população aos desfiles de 7 de setembro daquele ano. Em 13 de dezembro de 1968, o General Costa e Silva assinou o Ato Institucional $n^{\circ} 5$, na realidade, afirma-se hoje, que o texto do ato já estava pronto desde julho de 1968. (MOREIRA ALVES, 1985:130)

Na data de 30 de Janeiro de 1969, o General Costa e Silva, com base no Al-5, assinou o Ato Complementar $\mathrm{n}^{\mathrm{o}} 45^{4}$, onde ficava expresso que à aquisição de propriedade rural no território nacional só poderia ser feita por brasileiro ou por estrangeiro residente no país. Entendia-se por estrangeiro residente no país aquele que possuísse permanência definitiva. Este Ato Complementar foi regulamentado pelo Decreto-Lei $n^{\text {o }} 494$ de 10 de março de $1969^{5}$, que definia parâmetros e critérios para o acesso à terra por estrangeiros, além de proibir a doação, posse ou venda de terras pertencentes à União ou aos estados. Ficava, inclusive o governo com instrumento legal para desapropriar terras rurais em poder de pessoas estrangeiras.

Outra vez, ocorria a adoção de procedimentos legais com aparência "nacionalista", mas que, no fundo, revelavam e guardavam intenções, de fato, de não interferir no processo de entrada e apropriação dos recursos naturais do país pelo capital estrangeiro. Tudo indica, que estes atos visavam, antes de tudo, agradar e incorporar a chamada "facção nacionalista" das Forças Armadas ao processo de "endurecimento" da ditadura militar. Isto pode ser verificado, em primeiro lugar, pelo fato de que a lei não tinha qualquer caráter retroativo. O que vale dizer, só passava a ter efeito legal a partir daquela data. E, em segundo lugar, a ditadura militar, em 10 de outubro de 1969, no mesmo ano portanto, do Ato Complementar $n^{\circ} 45(30 / 01 / 69)$ e do decreto-lei $n^{\circ} 494$ (10/3/69), simplesmente excluía das disposições do Decreto-Lei no 494 "as aquisições de áreas rurais necessárias à execução de empreendimentos industriais considerados de

\footnotetext{
${ }^{4}$ Ver em anexo a íntegra do Ato Complementar $n^{\circ} 45$, de 30 de janeiro de 1969.

${ }^{5}$ Ver em anexo a íntegra do Decreto-Lei no 494, de 10 de Março de 1969.
} 
interesse para a economia nacional, cujos projetos tenham sido aprovados pelos órgãos competentes" (Artigo 1 ${ }^{\circ}$, Decreto-Lei n. 11.924 de 10/10/69).

Estava, portanto, aberta a possibilidade para que os projetos agropecuários e industriais da SUDAM, de propriedade de estrangeiros, por exemplo, ficassem fora dos novos requisitos da lei, o que quer dizer que poderiam controlar as áreas rurais que quisessem no país, desde que demonstrassem que eram necessárias ao desenvolvimento dos seus projetos. O Projeto Jari, de Mr. Daniel Ludwig, por exemplo, com seus mais de 5 milhões de hectares de terras, estava "salvo" da nova legislação.

Assim, atrás das medidas supostamente "nacionalistas", vinham medidas que procuravam garantir a continuidade do entreguismo das riquezas naturais do país. Era a economia brasileira internacionalizando-se, e os governos militares brasileiros constituindo-se em peças fundamentais nesse processo.

Retornando a seqüência das leis, em 1971, em pleno governo do General Médici e com o Congresso Nacional castrado e ordeiro (majoritariamente Arena, à época em que era o "maior partido político do Ocidente"), a ditadura militar aprovou a Lei $\mathrm{n}^{\mathrm{o}}$ $5.7097 / 10 / 71^{6}$, que passava a regular à aquisição de imóvel rural por estrangeiro residente no país ou pessoa jurídica estrangeira autorizada a funcionar no Brasil.

A Lei $n^{\circ} 5.709 / 71$ consagrava, portanto, todas as restrições e aberturas para o capital estrangeiro chegar à propriedade da terra no Brasil, além daquelas formas famosas de associação com brasileiros "testas-de-ferro" ou "laranjas" como são denominados na atualidade. E mais, ampliava as possibilidades de regularização das fraudes cometidas antes do Decreto-Lei de 10/03/69. Isto era possível porque a lei, ao contrário do Ato Complementar e do Decreto-Lei, permitia inclusive que, se os estrangeiros tivessem adquirido terras antes de 1969, teriam um prazo para regularizálas. Mais do que isto, permitia ao presidente da República, através de decreto, autorizar à aquisição de terras por estrangeiros além dos limites fixados em lei, desde que fosse julgada prioritária face aos planos de desenvolvimento do país.

Enfim, a empresa ou a pessoa física estrangeira, pela lei, passou a poder adquirir até $10 \%$ das terras de um município. Ou, se quisesse, podia seguir o "conselho" do exministro da Agricultura, Alysson Paulinelli, que quando ministro, em uma reunião com empresários estrangeiros em Salzburg, na Áustria, aconselhava estes grupos a burlarem a legislação brasileira, dizendo: "Basta pegar dois municípios vizinhos, comprar $10 \%$ de

\footnotetext{
${ }^{6}$ Ver em anexo a íntegra da Lei no 5.709 , de 7 de outubro de 1971.
} 
um e 10\% de outro". (SAUTCHUK et alli, 1979:77.) Este procedimento na Amazônia significava adquirir nos municípios paraenses de Altamira (16.075.499 hectares) e São Félix do Xingu (8.424.842 hectares) nada mais nada menos de 2.450.000 hectares, ou seja, uma área maior do que o estado de Sergipe. Enfim, de certo modo, "legalizava-se o escândalo", pois, como já foi afirmado, um dos escândalos era o Projeto Jari do Mr. Daniel Ludwig, cuja vinda para o Brasil originou-se de um convite feito pelo Marechal Castelo Branco: "Pode vir, Mr. Ludwig. O Brasil agora é um país seguro." (SAUTCHUK et alli, 1979:13)

Ficava, portanto, definido pelos militares que os estrangeiros poderiam apropriar-se legalmente de $25 \%$ do território brasileiro. Ou seja, poderiam adquirir 212.871.914,9 de hectares dos 851.487.659,9 hectares que o país possui.

Aliás, esta lei só foi regulamentada em 26 de setembro de 1974 pelo Decreto $\mathrm{n}^{\circ}$ $74.965^{7}$ já no governo do General Geisel, quando o país já se preparava para uma nova fase "pós-milagre". Entretanto, é bom que se reafirme, que o adiamento da regulamentação da lei só surgiu para que muitos escândalos fossem "legalizados" às custas dos "homens das multinacionais" no Planalto.

Um bom exemplo destes homens, como já afirmado anteriormente, foi o Major Heitor de Aquino Ferreira, que trabalhou para o grupo Ludwig no Brasil, de 1970 a 72, sendo apresentado nos documentos da empresa Jari Florestal e Agropecuária Ltda como "acionista". Foi este mesmo major que foi trabalhar em 1972 na Petrobras, com o General Geisel, passando em 1974, a fazer parte do governo, e, foi secretário particular do presidente da República, no governo do General Figueiredo, em 1979.

O país tinha vivido o episódio do "falso milagre", quer dizer, de um arrocho salarial dos mais profundo da história, aliado à maior expansão das multinacionais em território brasileiro, e tudo era euforia aparente. Tudo indica, que o único "punido" nesse escândalo da aquisição de terras por estrangeiros foi o "bode expiatório" chamado Mr. Stanley Amos Selig, que terminou assassinado no estado americano de Indiana por um dos compradores que enganara (SAUTCHUK et alli, 1979:78) e, cujas terras, segundo informações do cartório de Ponte Alta do Norte/GO (atual Ponte Alta do Tocantins/TO, foram passíveis de processos de anulação em 1976, por decisão da justiça. (OLIVEIRA, 1997:81/5)

\footnotetext{
${ }^{7}$ Ver em anexo a íntegra do Decreto $n^{\circ} 74.965$, de 26 de Novembro de 1974.
} 


\subsection{A legislação atual sobre à aquisição de terras por estrangeiros}

A Lei $n^{0} 5.709$ (7/10/71) é o diploma legal em vigor no país, relativo à aquisição de terras por estrangeiros. Essa lei, como se viu, limitou à aquisição de terras por estrangeiros em 50 módulos fiscais (o tamanho de um módulo varia de acordo com o município, sendo que o menor tem 5 hectares e o maior 110 hectares). Indicou também que a soma de imóveis rurais por estrangeiros não pode ultrapassar a quarta parte da superfície de um município e, uma mesma nacionalidade tem limitada o acesso à terra em $10 \%$ da área de um município.

Segundo o INCRA, a essa lei junta-se a legislação relativa à pessoa jurídica estrangeira autorizada a funcionar no Brasil, elaborado em pleno neoliberalismo privatista e de expansão dos investimentos internacionais no Brasil, do governo Fernando Henrique Cardoso. Foi o período conhecido como da remoção de todos os eventuais preceitos legais que permitisse a livre circulação do capital mundial. Assim, embora o INCRA fosse até 1995, responsável pelo controle da aquisição de terras por estrangeiros no Brasil, a Emenda Constitucional № 06 que revogou o artigo 171 da Constituição Federal de $1988^{8}$, o qual permitia distinção entre pessoa jurídica de capital nacional e de capital estrangeiro, alterou a compreensão em vigor. Ou seja, passou-se ao entendimento de que o parágrafo $1 .^{\circ}$ do artigo $1 .^{\circ}$ da Lei n. ${ }^{\circ} 5.709 / 71$, que permitia esse controle, havia sido revogado. Essa compreensão derivou do entendimento sobre pessoa jurídica brasileira emanado do Parecer $n^{\circ}$ GQ-181 de 17 de dezembro de 1998 que reexaminou o Parecer $\mathrm{n}^{\circ}$ AGU/LA-04/94, da Consultoria Geral da União (CGU), voltado para a orientação quanto à aquisição de imóveis rurais por estrangeiro. $\mathrm{O}$ Parecer definiu que o entendimento deveria ser o seguinte: pessoa jurídica brasileira cujo capital societário, mesmo que participe pessoa estrangeira, com qualquer percentual, seja física ou jurídica, não necessita requerer autorização para adquirir imóveis rurais no território nacional. Esse parecer vigorou até 2010, quando foi substituído pelo Parecer CGU/AGU No 01/2008-RVJ/10, que passou a requer o controle pelo INCRA das terras adquiridas por estrangeiros.

\footnotetext{
${ }^{8}$ Art. 171. São consideradas: I - empresa brasileira a constituida sob as leis brasileiras e que tenha sua sede e administração no País; II - empresa brasileira de capital nacional aquela cujo controle efetivo esteja em caráter permanente sob a titularidade direta ou indireta de pessoas físicas domiciliadas e residentes no País ou de entidades de direito público interno, entendendo-se por controle efetivo da empresa a titularidade da maioria de seu capital votante e o exercício, de fato e de direito, do poder decisório para gerir suas atividades.
} 
Neste período de vigência da lei, o número de imóveis rurais de estrangeiros caiu de 43.406 em 1972 para 23.967 em 1992, e, a área ocupada também caiu de 7,161 milhões de hectares em 1972 para 2,615 milhões em 1992. Com a modificação gerada nos anos 90, o número de imóveis de estrangeiros aumentou chegando em 2007, a 33.219 ocupando área de 3,833 milhões de hectares. Em 2009, o número de imóveis era de 34.371 e a área de 4,348 milhões de hectares.

Assim, na atualidade, os instrumentos legais que regem à aquisição de terras por estrangeiros são: Lei 5.709/71; Decreto 74.695/74; Lei 6.634/79; Decreto 85.064/80; Constituição Federal de 1988 o artigo 170, I, II e II, e os artigos 172 e 190; Lei 10.267/01; Decreto 4.449/02 e Decreto 5.570/05.

Essa legislação determina que os Cartórios de Registro de Imóveis tenham um cadastro especial, através de livro auxiliar, relativos à aquisição de imóveis rurais por pessoas estrangeiras físicas e jurídicas e, além disso, têm que informar o INCRA trimestralmente informações realizadas como manda a Lei 5709/71. Ficam também os cartórios obrigados pela Lei 10.267/01, a informar o INCRA, mensalmente os serviços de registros de imóveis, as modificações ocorridas nas matrículas imobiliárias decorrentes de: mudança de titularidade, parcelamento, desmembramento, loteamento, remembramento, retificação de área, reserva legal e particular do patrimônio natural e outras limitações e restrições de caráter ambiental.

Dessa forma, o INCRA tem o seguinte procedimento padrão quanto aos requisitos necessários para à aquisição ou arrendamento de terras por estrangeiros:

a) residir no Brasil (se pessoa física: carteira de identidade de estrangeiro e se jurídica: autorização para funcionar no País);

b) imóvel registrado no Cartório de Registro de Imóveis e cadastrado no Sistema Nacional de Cadastro Rural (SNCR);

c) se imóvel em área de Segurança Nacional ter o assentimento prévio do Conselho Nacional de Defesa;

d) área igual ou inferior a 03 Módulos de Exploração Indefinida - $\mathrm{MEI}^{9}$ não precisa de autorização do INCRA. Exceto, sendo a segunda aquisição ou imóvel em área de segurança nacional;

\footnotetext{
${ }^{9}$ O Módulo de Exploração Indefinida - MEI é unidade de medida, expressa em hectares, definida para cada imóvel rural inexplorado ou com exploração não definida, em função da Zona Típica de Módulo do Município de situação do imóvel. Varia de 05 a 100 ha. A Zona Típica de Módulo: são regiões delimitadas pelo INCRA, com características ecológicas e econômicas homogêneas, baseada na divisão
} 
e) área rural pertencente à pessoa física ou jurídica estrangeira não pode ultrapassar 1/4 da área do município onde o imóvel se situe;

f) pessoas da mesma nacionalidade não poderão ser proprietárias, em cada município de mais de $40 \%$ do limite fixado, que é de $1 / 4$ da área do município;

g) área de 03 a 50 módulos de exploração indefinida (MEI) requer autorização do INCRA;

h) não pode exceder a 50 módulos de exploração indefinida (MEI) (área contínua ou não);

i) imóvel não superior a 03 módulos de exploração indefinida (MEI) não depende de autorização ou licença, exceto se segunda aquisição ou área de segurança nacional;

j) Não se aplica a transmissão causa mortis; e

k) assentimento do Conselho de Segurança Nacional (área de segurança nacional/ faixa de fronteira $150 \mathrm{~km}$ ), sendo nula de pleno direito e sujeita responsáveis a responder civil e criminalmente.

As restrições quantitativas segundo o artigo $3^{\circ}$ da Lei 5709/71, artigo $7^{\circ} \S 2^{\circ}$ do Decreto 74965/74 e Constituição Federal de 1988 artigo 49, XVII, estão na Tabela 1 a seguir.

\section{Tabela 1}

\begin{tabular}{|l|l|}
\hline a) Até 03 MEI & $\begin{array}{l}\text { a) Aquisição Livre (exceção segurança nacional } \\
\text { ou segunda aquisição) }\end{array}$ \\
\hline b) 03 até 20 MEI & b) Autorização, sem projeto \\
\hline c) Mais de 20 MEI & c)Autorização e projeto de exploração \\
\hline d) Acima de 50 MEI (pessoa física) & d) Autorização Especial do Congresso Nacional \\
\hline $\begin{array}{l}\text { e) Acima de } 100 \text { MEI (pessoa } \\
\text { jurídica) }\end{array}$ & e) Autorização Especial do Congresso Nacional \\
\hline
\end{tabular}

microrregional do IBGE, considerando as influências demográficas econômicas de grandes centros urbanos. 


\section{3. Área ocupada por imóveis de estrangeiros no país, segundo o INCRA}

Os dados divulgados pelo INCRA sobre a área ocupada por imóveis de estrangeiros no Brasil tem sido diferente segundo a fonte da divulgação. Fato curioso é que esse órgão nunca divulgou em seu site os números oficiais referentes a terras de estrangeiros, eles sempre saíram somente na mídia, oferecidos, via de regra pelo seu expresidente. Dessa forma, em 08 de junho de 2008, o jornal Folha de São Paulo, informava que os dados consolidados em dezembro de 2007, indicavam a existência de 33.219 imóveis de estrangeiros ocupando área de 3,834 milhões de hectares.

Cabe ressaltar também, que segundo a distribuição regional a Amazônia Legal ficou com 35,4\% da área ocupada por esses imóveis; a região Norte 14,0\%; Nordeste 13,8\%; Centro-Oeste 37,2\%; Sudeste 23,1\%; e Sul 11,9\%. Sua distribuição pelas unidades da Federação está retratada na Tabela 02.

Entretanto, em entrevista ao jornal O Estado de São Paulo de 06/03/2008, o expresidente do INCRA, informou que havia sob o poder dos estrangeiros 33.228 imóveis ocupando uma área total de 5,6 milhões de hectares. Por sua vez, em 27/09/2008, o mesmo jornal O Estado de São Paulo, divulgou os seguintes dados relativos às terras de estrangeiros: 34.591 imóveis e 4.038.885,9 hectares de área ocupada.

Segundo esses dados divulgados em agosto de 2008 pelo INCRA, a distribuição regional ficou da seguinte forma: a Amazônia Legal com 34,6\% da área ocupada por estrangeiros; fora da Amazônia Legal ficaram 65,4\% da área dos imóveis, por sua vez, a região Norte ficou com 13,0\%; Nordeste 13,8\%; Centro-Oeste 38,0\%; Sudeste 23,4\%; e Sul $11,7 \%$.

Esses últimos dados divulgados mostram que os estrangeiros estão ocupando um percentual de apenas $0,5 \%$ do território brasileiro. Inclusive, nos estados onde esse percentual é maior, ele representa $2,2 \%$ no estado de São Paulo, $1,7 \%$ no Rio de Janeiro, 1,5\% no Paraná e 1,3\% no Mato Grosso do Sul. Os demais estados tem percentual inferior a 1\%. Na Amazônia Legal esse percentual é de $0,3 \%$, ou seja, os estrangeiros possuem 1.396.514 hectares dos 508.866.844 hectares que formam esta região brasileira. A distribuição pelas unidades da Federação estão na Tabela 03.

Esses dados são fundamentais, para mostrar que o "novo escândalo" da aquisição de terras por estrangeiros adquire uma característica de farsa a encobrir outros fatos políticos pelo governo do PT entre os quais estão a contra-reforma agrária em marcha, particularmente na Amazônia Legal, e a retirada da agenda política do país 
da reforma agrária como política pública de promoção do desenvolvimento econômico e social.

Assim, o caminho é destrinchar esse novo factóide do governo petista para não fazer a reforma agrária e, ao contrário, passar a fazer a contra-reforma agrária através das Medidas Provisórias 422 e 458.

Tabela 02

BRASIL - TERRAS DE ESTRANGEIROS

\begin{tabular}{|c|r|r|}
\hline & \multicolumn{1}{|c|}{ imóveis } & Área ocupada (ha) \\
\hline BRASIL & $\mathbf{3 3 . 2 1 9}$ & $\mathbf{3 . 8 3 4 . 5 1 0 , 7}$ \\
\hline MT & 1.377 & $754.705,4$ \\
\hline SP & 11.424 & $504.742,8$ \\
\hline MS & 749 & $423.148,1$ \\
\hline BA & 2008 & $361.316,8$ \\
\hline MG & 2.261 & $299.993,2$ \\
\hline PR & 5.316 & $299.622,9$ \\
\hline GO & 787 & $243.205,7$ \\
\hline PA & 1.168 & $231.860,0$ \\
\hline AM & 313 & $116.264,7$ \\
\hline TO & 187 & $107.237,0$ \\
\hline RS & 2.005 & $105.158,8$ \\
\hline RJ & 1.992 & $69.397,1$ \\
\hline MA & 184 & $64.672,0$ \\
\hline SC & 1.265 & $49.896,2$ \\
\hline RO & 172 & $37.243,8$ \\
\hline CE & 371 & $27.823,5$ \\
\hline PI & 75 & $24.619,3$ \\
\hline RR & 61 & $24.619,3$ \\
\hline AC & 31 & $14.071,0$ \\
\hline ES & 295 & $13.680,2$ \\
\hline AL & 101 & $13.424,1$ \\
\hline RN & 146 & $13.208,3$ \\
\hline PE & 383 & $12.510,3$ \\
\hline PB & 252 & $8.043,4$ \\
\hline AP & 16 & $6.428,0$ \\
\hline DF & 198 & $3.876,9$ \\
\hline SE & 82 & $3.741,9$ \\
\hline Fonte: INCRA Folha de 2 Paulo & & \\
\hline
\end{tabular}

Fonte: INCRA, Folha de São Paulo, 08/06/2008,.p. A4 
Tabela 3

BRASIL - TERRAS DE ESTRANGEIROS

\begin{tabular}{|l|r|r|}
\hline & imóveis & Área ocupada (ha) \\
\hline MT & 1.394 & $807.445,3$ \\
\hline SP & 12.312 & $544.491,5$ \\
\hline MS & 789 & $472.691,6$ \\
\hline BA & 2.139 & $380.125,9$ \\
\hline MG & 2.333 & $312.226,1$ \\
\hline PR & 5.382 & $306.724,1$ \\
\hline GO & 846 & $251.778,0$ \\
\hline PA & 1.146 & $235.750,5$ \\
\hline AM & 309 & $105.296,0$ \\
\hline TO & 183 & $104.475,4$ \\
\hline RS & 2.026 & $114.283,3$ \\
\hline RJ & 2.154 & $75.395,1$ \\
\hline MA & 178 & $65.099,9$ \\
\hline SC & 1.287 & $52.006,6$ \\
\hline RO & 130 & $34.647,5$ \\
\hline CE & 388 & $31.523,8$ \\
\hline PI & 81 & $33.080,0$ \\
\hline RR & 59 & $23.747,4$ \\
\hline AC & 26 & $13.624,0$ \\
\hline ES & 309 & $13.990,1$ \\
\hline AL & 103 & $13.624,0$ \\
\hline RN & 115 & $16.378,3$ \\
\hline PE & 350 & $8.448,0$ \\
\hline PB & 252 & $7.468,0$ \\
\hline AP & 16 & $6.428,0$ \\
\hline DF & $\mathbf{3 4 . 5 9 1}$ & $3.313,0$ \\
\hline SE & & $\mathbf{4 . 0 3 8 . 6 1 6 , 2}$ \\
\hline BRASIL & Jornal Estado de São Paulo, 27/08/2008, p.A20 \\
\hline Fonte: INCRA & \\
\hline & & . \\
\hline
\end{tabular}

\section{O atual "novo escândalo" de aquisição de terras por estrangeiros}

4.1. A elevação dos preços das terras no país, a crise mundial dos alimentos de 2008, e, na contra-mão da história, o segundo governo de Luiz Inácio faz a opção pela contra-reforma agrária

A crise dos alimentos de 2008 e sua consequência, a elevação dos preços das terras no país ocorreu, particularmente, até o mês de setembro. Vários jornais incumbiram-se de noticiar o fato. Por exemplo, o jornal Valor Econômico noticiou em janeiro daquele ano que os preços das terras para grão voltavam a subir. A razão principal do aumento era que estes estavam sendo

"impulsionados pela recuperação das cotações das commodities no mercado internacional ... O movimento de recuperação dos preços de terras teve início no segundo semestre de 2006 e se intensificou durante todo o ano passado. $\mathrm{O}$ último levantamento, realizado entre novembro e dezembro de 2007 , mostra valorização média no país de $17,83 \%$ em relação aos últimos 12 meses. No Brasil, as cotações médias passaram de $\mathrm{R} \$ 3.276$ por hectare para $\mathrm{R} \$ 3.860$."(VALOR ECONÔMICO, 17/01/2008:B13) 
O jornal Folha de São Paulo em fevereiro do mesmo ano, informava também, na seção "Terra em Transe", que investidores estrangeiros da Austrália, EUA e da Argentina estavam aplicando no Brasil na aquisição de terras. A reportagem, inclusive, indicava o exemplo de duas empresas com "lastro" em terra que tinham feito captação no mercado acionário das Bolsas de Valores e que estavam investindo em várias regiões do Brasil:

"o mesmo diagnóstico move duas empresas que participam do Novo Mercado da Bolsa de Valores de São Paulo. A demanda mundial por alimentos e biocombustíveis tende a se manter sólida -- mesmo que os EUA entrem em recessão -- puxada pelos emergentes asiáticos e pelo crescimento russo. Desde o IPO (oferta inicial de ações) em junho do ano passado, a SLC Agrícola investiu R \$ 88 milhões em quatro propriedades rurais, diz Laurence Gomes, diretor financeiro e de relações com investidores. O grupo, com sede em Porto Alegre (RS), tem 165 mil hectares em nove fazendas, com gestão padronizada, em cinco Estados - GO, MS, MT, BA e MA. O foco está na produção de soja, milho e algodão. 'Desenvolvemos novas unidades, sempre com diversificação geográfica para minimizar riscos climáticos', diz Gomes. A empresa conta com departamento voltado para a busca e a avaliação de terras. A BrasilAgro surgiu em 2005 para explorar oportunidades no mercado imobiliário agrícola brasileiro, diz Ivan Alves da Cunha, principal executivo da companhia. No ano passado, a empresa investiu R\$ 155 milhões na aquisição de cinco fazendas. Ao todo, o grupo dispõe de 143.683 hectares em oito propriedades, espalhadas por seis estados - MG, GO, MS, MT, BA, PI. De toda a área, 125 mil estão cultivados com grãos, algodão, cana e pastagens ... Os acionistas fundadores da BrasilAgro são a Cresud, a Tarpon e Cape Town. A Cresud está há 20 anos nesse ramo na Argentina, onde explora por volta de 600 mil hectares. A Tarpon Investimentos é uma empresa de administração de recursos independente. A Cape Town pertence a Elie Horn, presidente da Cyrela Brazil Realty, que atua no ramo imobiliário."(FOLHA DE SÃO PAULO, 10/02/2008:B3)

$\mathrm{O}$ artigo inclusive, mostrou que a elevação do preço do hectare em termos da média nacional havia passado de $\mathrm{R} \$ 3.139,00$ o hectare em janeiro/fevereiro de 2005 para R\$ 3.276,00 em janeiro/fevereiro de 2007, e, elevou-se novamente para $\mathrm{R} \$$ $3.860,00$ em novembro/dezembro de 2007. Ainda segundo o jornal:

"a produção em alta e intenção de plantio recorde para a safra 2007/2008 fizeram com que o preço da terra alcançasse valor recorde nominal em termos médios no país. Segundo pesquisa do Instituto FNP, consultoria privada especializada em agronegócio, ao longo de 2007, a valorização chegou a 17,83\%, ganho real (acima da inflação) de $9,6 \%$ no ano ... Para 2008, apesar da turbulência nos mercados internacionais, que poderiam prejudicar investimentos, a perspectiva é de nova alta, com os negócios ainda aquecidos. Os motivos, segundo especialistas, são: o preço dos grãos tende a se manter firme, a 
pecuária ensaia recuperação e os biocombustíveis têm espaço garantido pela frota flex, em que pese não haver a euforia de outros tempos na cana-de-açúcar. 'Os fundamentos melhoraram', diz Jacqueline Bierhals, responsável pela pesquisa de terras do Instituto FNP. Tomando um período mais amplo para análise, de três anos, o Estado de São Paulo registra as maiores valorizações absolutas no valor do hectare. As regiões de Araraquara, Bauru, Piracicaba, Ribeirão Preto e Pirassununga tiveram o valor do hectare duplicado em alguns casos em áreas para o cultivo da cana."( FOLHA DE SÃO PAULO, 10/02/2008:B1)

Dessa forma, diante esse cenário os fundos de investimento, incluindo estrangeiros, voltaram-se para o mercado de terras:

\begin{abstract}
"as regiões preferidas são as consideradas de fronteira, em Mato Grosso, no oeste baiano e no chamado 'Mapito' -- Maranhão, Piauí e Tocantins. A preferência se reflete nos números. Um hectare de terra agrícola que valia R\$ 4.482 em Luís Eduardo Magalhães, no cerrado baiano, no começo de 2007, passou a R 7.000 depois de um ano. No cerrado de Balsas (MA), o preço passou da faixa de $\mathrm{R} \$ 485 / \mathrm{R} \$ 890$ para $\mathrm{R} \$ 1.300 / \mathrm{R} \$ 1.430 \mathrm{em}$ igual período. Em Alta Floresta (MT), a terra de soja evoluiu de $\mathrm{R} \$ 1.360$ a $\mathrm{R} \$ 2.000$. A valorização da terra é um dos fatores que influenciam indiretamente o desmatamento no limite da fronteira agrícola. A formação das lavouras é o terceiro capítulo de uma história que sempre tem o primeiro ato com a exploração das madeiras. A segunda parte vem com a formação de pastos para a pecuária. O terceiro é o cultivo de grãos ou de plantações perenes. 'A minha empresa não recomenda comprar terra na Amazônia, onde a lei obriga a preservação de $80 \%$ da propriedade', diz Alcides de Moura Torres Junior, diretor da Scot Consultoria. ' $O$ ônus jurídico não compensa', afirma. A região de desmatamento não propicia nem um acompanhamento de um mercado formal. 'Há muita invasão, 'grilagem', não há como medir', diz Jacqueline Bierhals, da FNP. O máximo que existe é a exploração legalizada de seringueiras, para extrair o látex, e de palma, para obter óleo."( FOLHA DE SÃO PAULO, 10/02/2008:B1) (grifo meu)
\end{abstract}

Assim, a mídia econômica mostrava à sociedade brasileira, portanto, que o rentismo capitalista dos proprietários de terra estava em marcha altista. E, a razão econômica fundante estava na crise da produção de alimentos que o mundo passava a viver em decorrências das políticas neoliberais da década de 90 .

Mas, antes de entrar no atual "novo escândalo" de aquisição de terras por estrangeiros, é preciso lembrar que o ano de 2008 foi exemplar na revelação ao mundo na elevação dos preços das commodities, em particular, do aumento dos alimentos básicos da população mundial: trigo, milho e arroz. Estes três alimentos representam a produção mundial de mais de 2 bilhões de toneladas produzidas, portanto, muito mais 
que os apenas 200 milhões da produção de soja. Aliás, a soja só tem importância para o agronegócio no Brasil e na Argentina, pois nem mesmo nos Estados Unidos tem a importância que recebe no Brasil. A elevação dos preços dos alimentos indicava também, pela FAO, o aumento do número de pessoas no mundo que passavam fome. Este número chegou a um bilhão de pessoas.

Naquele mesmo ano, o jornal Folha de São Paulo, em sua página Tendências e Debates publicou um texto meu (OLIVEIRA, 2008:3) onde afirmei que a crise dos alimentos tinha relação entre a expansão dos agrocombustíveis e a produção de alimentos e, ressaltei que dois processos monopolistas comandavam e comandam a produção agrícola mundial. De um lado estava e está a territorialização dos monopólios que atuam simultaneamente, no controle da propriedade privada da terra, do processo produtivo no campo e do processamento industrial da produção agropecuária, o exemplo era e é o setor sucroalcooleiro, ou sucroenergético como eles estão autodenominando-se na atualidade. De outro lado, estava e está a monopolização do território desenvolvido pelas empresas de comercialização e/ou processamento industrial da produção agropecuária, que sem produzir absolutamente nada no campo, controlava e controla através de mecanismos de sujeição, camponeses e capitalistas produtores do campo. Estas empresas monopolistas do setor de grãos, atuavam e atuam como players no mercado futuro das bolsas de mercadorias do mundo, e, muitas vezes têm também, o controle igualmente monopolista da produção dos agrotóxicos e dos fertilizantes.

A crise, portanto, tinha dois fundamentos. O primeiro, de reflexo mais limitado, referia-se na época, à alta dos preços internacionais do petróleo e conseqüente elevação dos custos dos fertilizantes e agrotóxicos. O segundo era conseqüência do aumento do consumo, mas não do consumo direto como alimento como queria fazer crer o governo brasileiro, mas sim, decorria da opção norte-americana da produção do etanol a partir do milho. Este caminho levou à redução dos estoques internacionais deste cereal, e com ele elevação de seus preços e dos demais grãos: o trigo, o arroz e a soja. Assim, a "solução" norte-americana contra o aquecimento global tornou-se o paraíso dos ganhos fáceis dos players dos monopólios internacionais que nada produzem, mas sujeitam produtores e consumidores à sua lógica de acumulação. Certamente, não há caminho de volta para a crise, pois, no caso norte-americano os solos disponíveis para o cultivo são disputados entre trigo, milho e soja. $\mathrm{O}$ avanço de um reflete inevitavelmente no recuo dos outros, por isso a crítica radical de Jean Ziegler da ONU: "etanol: crime contra a humanidade". 
Era pois, no interior desta crise que o agronegócio do agrocombustível brasileiro tentava pegar carona no futuro, fundado na reprodução do passado. E mais, o governo estava a pavimentar-lhe o caminho. Por isso, a questão dos agrocombustíveis e a produção de alimentos rebateram diretamente no campo brasileiro. A área plantada de cana na safra de 2007, chegara perto de 7 milhões de hectares e, em São Paulo onde se concentra mais de $50 \%$ deste total, ela já ocupava quase a totalidade dos solos mais férteis existentes.

Em meio a esta expansão dos agrocombustíveis, uma pergunta se fazia necessária: quais haviam sido as conseqüências para a produção de alimentos no Brasil da expansão da cultura da cana nos últimos quinze anos?

Os dados do IBGE entre 1990 e 2006 revelavam a redução da produção dos alimentos imposta pela expansão da área plantada de cana-de-açúcar que cresceu neste período mais de 2,7 milhões de hectares. Tomando-se os municípios que tiveram a expansão de mais de 500 hectares de cana no período, verificava-se que neles ocorrera a redução de 261 mil hectares de feijão e 340 mil de arroz. Nesta área reduzida poder-seia produzir 400 mil toneladas de feijão, ou seja, 12\% da produção nacional e, um milhão de toneladas de arroz equivalente a $9 \%$ do total do país. Além, disso reduziram-se nestes municípios a produção de 460 milhões de litros de leite e mais de 4,5 milhões de cabeças de gado bovino.

Assim, os dois principais setores a pressionar o crescimento da aquisição de terras por estrangeiros eram muito mais, o sucroenergético e o de celulose e madeira plantada, ou seja, onde ocorre a territorialização dos monopólios. O primeiro setor, em função da compra de empresas nacionais (usinas e destilarias) pelas multinacionais que tinham em seus ativos muita terra, além, do crescimento da demanda de etanol motivada pela ampliação da frota de carros flex. E, o segundo porque tinha planos de expansão e necessitava de plantar mais áreas com silvicultura. Já onde se dá a monopolização do território, particularmente, no setor de grãos, o crescimento embora contenha também, a presença de estrangeiros, se faz muito mais por segmentos da burguesia brasileira e do campesinato tecnificado, ambos em aliança subordinada com as empresas mundiais. É importante destacar que embora a expansão esteja mais concentrada em São Paulo, ela já está acontecendo também, no Paraná, Mato Grosso do Sul, Triângulo Mineiro, Goiás e Mato Grosso. E, também nestes estados, ela está reduzindo a área de produção de alimentos agrícolas e desloca a pecuária na direção da Amazônia onde é responsável 
consequentemente, pelo desmatamento. Por isso, a expansão dos agrocombustíveis continuará a gerar a redução da produção de alimentos.

Assim, não é demais lembrar que a produção dos três alimentos básicos no país, arroz, feijão e mandioca, também não crescem desde os anos noventa, e mais, o Brasil tornou-se o maior país importador de trigo do mundo. Portanto, o caminho para a saída da crise e da construção de uma política de soberania alimentar continuava e continua sendo a realização de uma reforma agrária ampla, geral e massiva.

Entretanto, na contra-mão da história, o governo do PT no segundo mandato do governo de Luiz Inácio agiu como no passado Collor/Itamar e FHC, ou seja, terminado o II PNRA, sem que sequer a metade das metas das 540 mil famílias assentadas fosse atingida, o governo não elaborou o III PNRA. Assim, o segundo mandato começava revelar sua real intenção: iniciar a contra-reforma agrária. Ou seja, era a banda podre dos funcionários do INCRA, fazendo valer sua intenção de "vender" as terras públicas da reforma agrária para os grileiros das mesmas. Dessa forma, a contra-reforma agrária do segundo mandato de Luiz Inácio, consagrou a regularização fundiária como política mestre do governo. A parte dos funcionários corruptos em aliança com os grileiros finalmente, estavam vencendo a luta pela reforma agrária. É esta a questão que está por traz da divulgação da notícia da aquisição de terras por estrangeiros no Brasil pelo próprio ex-presidente do INCRA Rolf Hackbart. Ela visou levar os movimentos socioterritoriais e sindicais a se envolverem com o debate, deixando no esquecimento a reforma agrária e passando inclusive, por consequência, apoiar a regularização fundiária e o Programa Terra Legal, o instrumento principal da contra-reforma agrária. É por isso, que em termos de luta política quase nada foi feito contra as Medidas Provisórias 422 e 458, além de uma carta aberta ao Presidente da República e ao Congresso Nacional solicitando a revogação imediata da Medida Provisória 422.

É preciso deixar claro em termos mundiais, que não estou aqui afirmando que não haja movimentos de capitais na direção de aquisição de terras no mundo capitalista neste período histórico, estou apenas insistindo que ele não é diferente do que ocorreu no Século XX. Portanto, essa questão não é específica e nem vem marcada por peculiaridades específicas deste início de Século XXI. Aliás, no Brasil como demonstrei anteriormente, a questão não tem a importância que se quer dar a ela, e é isso que procuro mostrar com este texto. 


\subsection{O "escândalo" da aquisição de terras por estrangeiros fabricado pelo INCRA}

Como afirmei anteriormente, o ano de 2008 iniciou-se sob dois signos: a crise mundial de alimentos e a expansão dos agrocombustíveis. Mas, a estes dois signos juntou-se no Brasil, a não elaboração pelo segundo governo de Luiz Inácio do III Plano Nacional de Reforma Agrária, inclusive sem nenhuma cobrança dos movimentos socioterritoriais e sindicais e da maior parte da intelectualidade de esquerda do país, e, a preparação do cenário conformista da contra-reforma agrária advindo das Medidas Provisórias 422 e 458. É possível que a estes dois outros signos somem-se outros que a investigação acadêmica cuidadosa não conseguiu ainda detectar.

Vou apresentar aqui o cenário no qual se deu o ponta pé inicial da difusão do que estou chamando de "novo escândalo" da aquisição de terras por estrangeiros no Brasil "fabricado" pelo ex-presidente do INCRA Rolf Hackbart, e, como foi uma pretensa peça teatral de mau gosto, será apresentado em vários atos.

ATO 1 - As cortinas são abertas: a esquerda em movimento, a entrevista de João Pedro Stedile à TV Estadão.

A TV Estadão (www.estadao.com.br) fez uma entrevista com João Pedro Stedile liderança nacional do MST no dia 21/02/2008. Nesta entrevista, segundo o jornal O Estado de São Paulo,

"o líder do MST João Pedro Stedile disse que, enquanto os sem-terra são tratados como fora-da-Iei, o capital internacional tem liberdade para adquirir extensas áreas em zonas restritas aos brasileiros. 'A Stora Enso comprou 86 mil hectares em área de fronteira no Rio Grande do Sul, de mais de 400 propriedades, expulsando pequenos e médios agricultores para impor a monocultura do eucalipto, que é predadora do meio ambiente', afirmou Stedile. E fez uma conclamação ao Exército. 'Atenção militares nacionalistas, nos ajudem a expulsar os finlandeses da fronteira.' $\mathrm{O}$ discurso de Stedile foi uma referência à Lei da Faixa de Fronteiras, que exige a aprovação prévia do Conselho de Defesa Nacional para aquisição de terras feita por estrangeiros em qualquer lugar situado até o limite de 150 quilômetros para dentro do território nacional, a partir da linha divisória com outros países."(O ESTADO DE SÃO PAULO, 04/03/2008:A10) 


\section{ATO 2 - No centro do palco o capital estrangeiro: o não aceite dos registros das terras da Stora Enso no Rio Grande do Sul pelo INCRA}

O jornal O Estado de São Paulo noticiou na seção Questão Fundiária no dia 04/03/2008, matéria relativa a problemas, que a multinacional sueco-finlandesa Stora Enso estava enfrentando com o INCRA. O órgão não estava aceitando os registros das compras de suas terras exatamente na faixa de fronteira no Rio Grande do Sul. O título da matéria era "Compra de terras por múlti no RS reabre debate sobre fronteiras". Ou seja, a reportagem visava abrir o debate sobre a legislação específica sobre a terra na faixa de fronteira, que vem sendo tentada à vários anos, pois lá está uma parte das terras públicas devolutas apropriadas privadamente de forma ilegal.

O texto começava assim:

"um projeto da multinacional sueco-finlandesa Stora Enso, que quer adquirir 120 mil hectares de terras para plantar eucaliptos em 11 municípios do sudoeste do Rio Grande do Sul ... A Stora Enso anunciou no fim de 2005 a intenção de formar uma base florestal no Rio Grande do Sul para abastecer de matéria-prima futura fábrica de celulose - um investimento inicial de US\$ 250 milhões que pode criar 1.600 empregos diretos e indiretos ao fim do primeiro ciclo florestal, de sete anos, fora os da indústria, que exigirá investimentos de mais US\$1 bilhão." (O ESTADO DE SÃO PAULO, 04/03/2008:A10)

Entretanto, a invés de cumprir a legislação brasileira sobre à aquisição de terras por estrangeiros e sobre a legislação específica referente à aquisição de terras da faixa de fronteira, a empresa dirigida por executivos brasileiros propôs simplesmente a burla da lei, alegando a existência de "um vazio jurídico" sobre a questão. Eis as afirmações dos dirigentes da empresa segundo o jornal:

"quando começou a atuar no País, a Stora Enso constituiu uma subsidiária, a Derflin Agropecuária Ltda., que adquiria as terras, mas tinha dificuldades para registrá-Ias nos cartórios. Os processos de aquisição eram encaminhados ao Instituto Nacional de Colonização e Reforma Agrária (INCRA), para instruí-Ios e repassá-Ios ao Conselho de Defesa Nacional. Como a análise chega a levar dois anos, a compra ficou num vazio jurídico (SIC) ... A solução (SIC) encontrada pela multinacional foi abrir uma empresa transitória, a Azenglever Agropecuária Ltda., em nome de seus executivos brasileiros Otávio Pontes e João Borges, para a qual a titularidade das terras foi transferida. Quando todas as aquisições estiverem aprovadas pelo Conselho de Defesa Nacional, a Azenglever será incorporada pela Derflin. Por solicitação de setores contrariados com o projeto, o repasse dos imóveis para a Derflin gerou pelo menos três 
investigações - uma do Ministério Público Federal, outra da Polícia Federal e uma terceira da Corregedoria Geral do Tribunal de Justiça que, por solicitação do INCRA, está averiguando se os cartórios burlaram a legislação ao aceitar registros em nome da Azenglever. Nenhuma delas chegou à conclusão até o fim de fevereiro." (O ESTADO DE SÃO PAULO, 04/03/2008:A10)

Mas, o que é mais incrível, é a afirmação do vice-presidente da Stora Enso para a América Latina, Otávio Pontes como um verdadeiro réu confesso cometendo um crime contra a legislação brasileira. A matéria do jornal segue informando que

"o INCRA se opõe sistematicamente ao negócio - o que o leva a acreditar em razões políticas: 'Cumprimos as exigências, mas o projeto não anda.' A criação de uma segunda empresa para o registro de terras foi a alternativa (SIC) encontrada pela Stora Enso para vencer a resistência do INCRA: 'Falam que usamos laranjas, mas tivemos que usar esse recurso para continuar trabalhando no meio de tanta insegurança jurídica'." (O ESTADO DE SÃO PAULO, 04/03/2008:A10)

Mas, ao contrário da opinião de João Pedro Stedile sobre o caso, a matéria traz informações de que alguns políticos do Rio Grande do Sul estão agindo não só contra a lei, mas também, a favor da aquisição de terras por estrangeiros na própria faixa de fronteira:

"o suplente de deputado Matteo Chiarelli (DEM-RS) apresentou um
projeto que reduz a faixa de fronteira para 50 quilômetros nos Estados
do Sul. O titular, Nelson Proença (PPS-RS), voltou ao cargo no início
deste ano e trabalha pela aprovação da mudança. O senador Sérgio
Zambiasi (PTB-RS) conseguiu aprovar na Comissão de Constituição
de Justiça do Senado, no dia 21 de janeiro, proposta da emenda
constitucional que reduz a faixa para 50 quilômetros do Chuí (RS) até
a divisa de Mato Grosso do Sul com Mato Grosso. A proposta deve
seguir para o plenário e depois para a Câmara. Zambiasi nega ter
agido para proteger os interesses da Stora Enso. 'Eu nem conheço esse
caso', afirmou, justificando ter apresentado o projeto porque é da
Comissão do Mercosul e por perceber que a legislação atrapalha
planos de desenvolvimento e recepção de investimentos de 197 dos
496 municípios gaúchos." (O ESTADO DE SÃO PAULO,
$04 / 03 / 2008: A 10)$ (grifo meu)

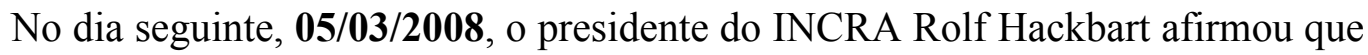
compra de terras na fronteira pela Stora Enso era ilegal. E, inclusive, salientou que instalação da indústria de papel da multinacional em território gaúcho afrontava a legislação brasileira. Assim, o jornal O Estado de São Paulo veiculou a notícia: 
"em entrevista ao Estado, o presidente do instituto, Rolf Hackbart, disse na terça-feira, 4, que a instalação de uma nova indústria de papel em território gaúcho, próxima à fronteira com o Uruguai, afronta a legislação brasileira. Hackbart negou as acusações de perseguição política, feitas por executivos da Stora Enso. O entrave, disse ele, está relacionado à compra de 110 mil hectares de terras para reflorestamento com eucalipto - matéria-prima da futura indústria, que teria um investimento inicial de US\$250 milhões (cerca de R $\$ 425$ milhões). 'O ponto mais importante da discussão é a soberania, o controle sobre o território', disse Hackbart, referindo-se à Lei de Faixa de Fronteiras, que impede a compra de terras por estrangeiros nessa área. 'O INCRA segue o que determina a lei."'(O ESTADO DE SÃO PAULO, 05/03/2008:A8) (grifo meu)

A matéria trouxe também, entrevista com o superintendente do INCRA do Rio Grande do Sul, que revelou também a mentira do dirigente da multinacional em relação aos documentos dos imóveis, revelando que eles cobriam apenas 17 mil hectares:

"em Porto Alegre, o superintendente regional do INCRA, Mozar Dietrich, também negou qualquer tipo de perseguição à empresa, que desde 2005 tenta sem sucesso levar adiante o projeto da indústria. 'Embora os procuradores do INCRA tenham alertado sobre a ilegalidade da compra de terras por estrangeiros em faixa de fronteira, a empresa começou a comprar fazendas e a plantar eucaliptos', afirmou o superintendente. 'Acusam-nos de atraso na análise dos processos de compra de terras, mas na prática ocorre o contrário', disse. 'Dos 46 mil hectares que já adquiriu, a empresa só entregou os documentos de 17 mil.' Dietrich é categórico: com a legislação em vigor é impossível a aprovação da compra de terra." "(O ESTADO DE SÃO PAULO, 05/03/2008:A8) (grifo meu)

\section{ATO 3 - O movimento sócio-territorial entra em cena: as mulheres da Via Campesina ocuparam área da Stora Enso no Rio Grande do Sul}

Na mesma madrugada do dia 04/03/2008, o mesmo dia da divulgação pelo jornal O Estado de São Paulo deu a notícia relativa às ilegalidades praticadas pela multinacional Stora Enso no Rio Grande do Sul, o Movimento das Mulheres da Via Campesina, como parte da jornada de lutas pela soberania alimentar e contra o agronegócio e as monoculturas do eucalipto, soja e cana-de-açúcar programada para a semana da comemoração do Dia Internacional da Mulher (8 de março), ocuparam a Fazenda Tarumã, em Rosário do Sul, no sudoeste do Rio Grande do Sul. A ação foi realizada em 
"protesto contra o plantio de eucaliptos que a multinacional suecofinlandesa está promovendo na propriedade rural de 2,1 mil hectares. A Via Campesina também está protestando contra os projetos que tramitam na Câmara Federal e no Senado para reduzir a faixa de fronteira, de 150 quilômetros para 50 quilômetros, o que facilitaria à aquisição de terras por estrangeiros na região." (O ESTADO DE SÃO PAULO, 05/03/2008:A8)

Na mesma tarde do dia 04/03, a Brigada Militar do Rio Grande do Sul usando de violência e prisões, retirou as mulheres da fazenda. Também, em protesto a esta violência, os integrantes da Via Campesina bloquearam oito trechos de rodovias gaúchas no dia seguinte.

\section{ATO 4 - A "Ilha da Fantasia" rouba a cena: a audiência pública da Comissão de Agricultura do Senado Federal sobre à aquisição de terras por estrangeiros}

Também no dia 04/03/2008, o mesmo da ação do Movimento das Mulheres da Via Campesina que ocuparam a fazenda Tarumã em Rosário do Sul- RS, o expresidente do INCRA Rolf Hackbart fez um depoimento na Comissão de Agricultura do Senado Federal para abordar a questão da aquisição de terras por estrangeiros no Brasil. Segundo reportagem do jornal O Estado de São Paulo, ele afirmou que

"a procura de terras brasileiras por estrangeiros, sejam pessoas físicas ou jurídicas, está crescendo de maneira acentuada em diversas partes do País e sem nenhum controle. A demanda seria impulsionada pela busca de áreas para a produção de cana-de-açúcar, pela valorização das commodities agrícolas e também para investimentos. 'Os grandes fundos de pensão do exterior tendem a investir cada vez mais em imóveis rurais brasileiros', afirmou Hackkbart ... Depois de descrever esse cenário, ele defendeu a adoção urgente de medidas destinadas a restringir as vendas. 'Não se trata de xenofobia. O ponto central é a proteção da soberania nacional.' Ainda de acordo com Hackbart, a Advocacia-Geral da União (AGU) deve anunciar brevemente medidas que limitarão os negócios com estrangeiros." (O ESTADO DE SÃO PAULO, 06/03/2008:A10) (grifo meu)

Outro depoimento na audiência pública foi feito pelo consultor-geral da AGU, Ronaldo Cesar Araújo:

"segundo o consultor, a instituição prepara, a pedido do INCRA e de outros órgãos do governo, parecer sobre o assunto. A tendência, anunciou, é ampliar o controle sobre as vendas a estrangeiros. $\mathrm{O}$ novo parecer, segundo Araújo, deve frear os negócios feitos por empresas brasileiras com capital internacional, o maior grupo comprador. Os outros são formados por empresas exclusivamente estrangeiras, com 
sede no exterior, que ainda enfrentam restrições; e pelas "laranjas" empresas aparentemente brasileiras, mas com capital de fora do País. Até 1997, todas as empresas com dinheiro estrangeiro enfrentavam pesadas restrições advindas da Lei 5.709, de 1971. A partir de 150 hectares, por exemplo, o comprador estrangeiro tinha de pedir autorização especial às autoridades federais. Os cartórios de registro de imóveis deviam comunicar às autoridades qualquer negócio com estrangeiros. Naquele ano, porém, o então advogado-geral da União, Geraldo Quintão, divulgou um parecer, baseado na Constituição de 1988, segundo o qual não se devia fazer distinção entre empresa brasileira e empresa brasileira com capital estrangeiro." (O ESTADO DE SÃO PAULO, 06/03/2008:A10) (grifo meu)

Ainda segundo o jornal, Rolf Hackbart teria afirmado que desde o parecer de Geraldo Quintão da AGU, "as autoridades começaram a perder o controle sobre as vendas. 'Não sabemos quanto de nossas terras estão em mãos de estrangeiros', disse." (O ESTADO DE SÃO PAULO, 06/03/2008:A10) Ainda segundo a reportagem, "o cadastro do INCRA - que não está atualizado e é montado com base em declarações dos proprietários - existem 33.228 imóveis registrados em nome de estrangeiros, 0,64\% do total cadastrado. São 5,6 milhões de hectares -- o equivalente a $0,97 \%$ do conjunto. A maior fatia -- 3,1 milhões de hectares -- está na Amazônia Legal." (O ESTADO DE SÃO PAULO, 06/03/2008:A10) No mesmo dia, um arquivo da apresentação feita no depoimento na Comissão de Agricultura por Rolf Rackbart é veiculado nas listas de Emails na Internet, sob o título: Amazônia Legal - Aquisição de Imóveis Rurais por Estrangeiros.

\section{ATO 5 - A verdade no centro do espetáculo: a legalização da grilagem de terra na Amazônia Legal, ou o governo de Luiz Inácio elabora a Medida Provisória 422}

A grilagem das terras públicas da Amazônia sempre veio alimentada pelas políticas públicas dos diferentes governos nos últimos cinqüenta anos. Primeiro foi a "Marcha para o Oeste" de Getúlio Vargas. Depois, os incentivos fiscais da SUDAM, da ditadura militar formulados pelo então ministro Delfim Neto. E por último, FHC e Luiz Inácio, e a aliança com a bancada ruralista no Congresso e as prorrogações infindáveis de suas dívidas que nunca são ou serão pagas.

Mas, qual foi a mudança na estratégia de ação do agronegócio na apropriação privada das terras públicas da Amazônia?

O uso da grilagem foi sendo sofisticado. Agora, não é mais necessário envelhecer os documentos com a ajuda dos grilos. Três novos recursos passaram a ser 
utilizados. Primeiro, não é mais necessário os insetos - grilos - para envelhecê-los como no passado, basta usar-se o forno de micro-ondas. Segundo, foi a estratégia de tentar regularizar as terras através de "laranjas", via falsas procurações. Foi o período que denominei de "grilagem legalizada" durante os governos militares. Ou seja, o grileiro interessado entrava com o pedido de "compra" da área. O máximo que podia adquirir, entre 1946 e 1967, era de 10.000 hectares. Depois esta área foi reduzida entre 1967 e 1988, para 3.000 hectares e, após 1988, para 2.500 hectares. A denúncia deste expediente gerou inúmeras Comissões Parlamentares de Inquéritos, cuja única conseqüência, foi a introdução nos Atos das Disposições Constitucionais Transitórias da Constituição de 1988 do artigo 51 onde está prevista a revisão por Comissão Mista do Congresso Nacional de "todas as doações, vendas e concessões de terras públicas com área superior a três mil hectares, realizadas no período de $1^{o}$ de janeiro de 1962 a 31 de dezembro de 1987”. Entretanto, até hoje o Congresso nada fez para providenciar esta revisão.

Terceiro, com a "Nova República", veio o I Plano Nacional de Reforma Agrária e a nova Constituição. A partir daí, o destino das terras públicas, insisto devolutas ou não, porque segundo o Supremo, devolutas são todas as terras públicas não discriminadas, passou a ser regido pelo artigo 188 da Constituição: “A destinação de terras públicas e devolutas será compatibilizada com a política agrícola e com o plano nacional de reforma agrária." Mesmo assim, há nos protocolos do INCRA das diferentes superintendências da Amazônia Legal, pedidos para "comprar" todas as terras públicas arrecadadas e discriminadas. Trata-se como diria Leonel Brizola, de um verdadeiro crime lesa Pátria.

Como a Constituição de 1988, manda compatibilizar a destinação das terras públicas com o plano nacional de reforma agrária, uma nova estratégia passou a ser montada para continuar favorecendo os grileiros do agronegócio. Uma parte dos funcionários do INCRA, particularmente os que "cuidam" do Cadastro, e que sempre estiveram envolvidos em corrupção, acusados de "venda" de terras públicas na Amazônia, passaram a "oferecer" e "reservar" as terras públicas para os grileiros e indicar o caminho "legal" para obtê-las. Portanto, quem está realizando a "grilagem legalizada" é a banda podre dos próprios funcionários corruptos do INCRA e dos órgãos estaduais de terra.

A denúncia destes fatos, já levou a Polícia Federal a fazer a Operação Faroeste no Pará e mandar para a prisão altos funcionários do INCRA, como o ex- 
superintendente José Roberto de Oliveira Faro, atual deputado federal e autor do PL 2289/07 que pretende ser a nova lei sobre aquisição de terras por estrangeiros, que será tratado em outra parte deste texto. Também, o Ministério Público moveu ação para cancelar os "assentamentos da reforma agrária laranja" da regional de Santarém. O motivo é sempre o mesmo: a tentativa de "oficializar" a grilagem das terras públicas. Várias outras operações da Polícia Federal foram realizadas levando superintendentes e diretores do INCRA para a prisão, tais como: Lacraia em Barra do Garças/MT; Pluma em São Félix do Araguaia/MT; Dupla Face em Cuiabá; TM e Saúde no Pará; Donatário no Maranhão; Orcrim ESA, Dinizia II e Terra Limpa em Rondônia; Terra Nostra no Tocantins; Cristal Negro em Goiás; Areal em Pernambuco; Navalha em Alagoas; Tellus no Mato Grosso do Sul e, a última foi em São Paulo, a Operação Desfalque. ${ }^{10}$

A sociedade brasileira precisa saber que o INCRA, desde os governos militares, arrecadou e/ou discriminou, um total de 105.803.350 hectares distribuídos pelos Estados na Amazônia Legal. Deste total, o INCRA até o ano de 2003, durante a elaboração do II PNRA do governo Luiz Inácio, tinha destinado um total de 37.979.540 hectares, e, possuía ainda sem destinação 67.823 .810 hectares. Estas terras públicas do INCRA estavam assim distribuídas: Rondônia 4.907.824 ha; Acre 6.291.734 ha; Amazonas 20.962.020 ha; Roraima 9.208.315 ha; Pará 17.934.669 ha; Amapá 0; Tocantins 1.031.876 ha; Mato Grosso 5.756.448 ha; e Maranhão 1.730.924 ha.

O que é mais espantoso de tudo, é que todas estas terras estão "cercadas e apropriadas privadamente". Os funcionários corruptos do INCRA "venderam" praticamente quase todo este patrimônio público, e, estão junto como os governos do PT, propondo soluções "jurídicas” para legalizar o crime cometido. Foi por isso, que no final do ano de 2005, conseguiram colocar no meio da famosa "Medida Provisória do Bem" (Lei no 11.196 de 21/11/2005) o artigo 118, que passou a permitir a regularização das terras na Amazônia Legal até 500 hectares, quando o artigo 191 da Constituição autoriza a posse apenas até 50 hectares. Aliás, não custa lembrar que a Lei $n^{\circ} 6.383$ de 07/12/76 dos militares, que dispõe sobre o processo discriminatório de terras devolutas da União, autoriza legitimação de área de posse de apenas 100 hectares. Outro instrumento legal elaborado foi a Instrução Normativa $n^{0} 32$ de 17/05/2006 do INCRA, que fixou os procedimentos legais para que o crime de uma parte da grilagem das terras públicas pudesse começar a ser legalizado.

\footnotetext{
${ }^{10} \mathrm{http} / / /$ www7.dpf.gov.br/DCS/operacoes/indexop.html - Acessado em 27/07/2011, às 23:03hs.
} 
Se não bastasse este ato do governo Luiz Inácio, afrontando as conquistas da Constituição Federal de 1988, em 11 de junho de 2007, o INCRA baixou a Instrução Normativa $n^{0}$ 41, publicada no DOU em 18/06/2007. Esta nova norma simplesmente estabeleceu "critérios e procedimentos administrativos referentes à alienação de terras públicas em áreas acima de 500 hectares limitadas a 15 (quinze) módulos fiscais mediante concorrência pública." Como o maior módulo fiscal na Amazônia é de 100 hectares, a área máxima será de 1.500 hectares. Esta Instrução Normativa era simplesmente uma afronta aos princípios constitucionais e, particularmente, tudo o que o Partido dos Trabalhadores pregou antes de sua chegada a presidência da República. Assim, o governo de Luiz Inácio estava fazendo o que nenhum governo, depois dos militares, havia feito, ou seja, estava "vendendo" ao agronegócio as terras públicas do INCRA na Amazônia.

Mas, esses instrumentos legais não foram considerados suficientes pela parte dos funcionários corruptos do INCRA. E, a sordidez destes dilapidadores do patrimônio público não teve limite. Em primeiro lugar, tentaram com auxílio do agrobanditismo paraense, que o deputado Asdrúbal Bentes (PMDB), ex-superintendente do INCRA em Marabá, apresentasse um projeto de lei que ampliava para até 15 módulos fiscais (1.500 hectares) a dispensa de licitação e conseqüente autorização para venda aos grileiros das terras do INCRA e da reforma agrária.

Em segundo lugar, a desfaçatez do governo do PT da DS (Democracia Socialista) no MDA/INCRA parecia que não tinha mais limite, pois, Luiz Inácio e Cassel, descaradamente, em nome da reivindicação da base aliada, transformaram (plagiaram) o projeto de lei do deputado Asdrúbal Bentes, na Medida Provisória no 422 de 25/03/2008. Seu texto seguindo o caminho da "MP do Bem", também alterou novamente a Lei $n^{\circ} 8.666 / 93$, permitindo a dispensa de licitação para alienar os imóveis públicos da União até 15 módulos fiscais (1.500 hectares) dando preferência aos seus grileiros. Esta MP foi aprovada pelo Congresso Nacional e transformada na Lei $\mathbf{n}^{\mathbf{0}}$

\subsection{3 de $01 / 08 / 2008$.}

Dessa forma, como 39\% da área dos municípios da Amazônia Legal têm módulos fiscais de 100 hectares, esta dispensa de licitação atingirá áreas griladas até 1.500 hectares. Estes municípios estão principalmente nos estados do Amazonas, Acre, Roraima, Mato Grosso e Pará, todos repletos de exemplos da grilagem de terras do INCRA. Outros 38\% da área dos municípios que têm módulos entre 75 e 90 hectares, e, a dispensa de licitação atingirá áreas griladas entre 1.125 e 1.350 hectares dos estados 
anteriores e do Tocantins e Maranhão. Ou seja, as terras griladas que serão regularizadas têm área acima de mil hectares, e, foi o próprio INCRA que reconheceu o crime: "assim, entre 70 e 80\% das posses de até 15 módulos fiscais estará em torno de 1000 ha, ou menos". 11 Aliás, foi o próprio ex-diretor de Ordenamento da Estrutura Fundiária do INCRA, Roberto Kiel, que reafirmou a adesão total ao agrobanditismo: “agora eles poderão comprar do governo federal as terras que já ocupavam há anos e não vão precisar de concorrer com outros interessados" $" 12$. (grifo meu)

Outra parte desta engenhosa operação para legalização da grilagem de terras do INCRA na Amazônia Legal foi aproveitar o aumento do desmatamento naquela região para fazer o recadastramento dos imóveis. Ele permitiu que os grileiros que ainda não tinham cadastrados as terras públicas que grilaram até dezembro de 2004, pudessem fazê-lo, e assim se habilitarem para "comprar" as terras griladas sem licitação. Aliás, a notícia no site do INCRA sobre o recadastramento, de forma absurda, já reconhecia os grileiros como posseiros: "Os donos ou posseiros de áreas maiores que quatro módulos fiscais [...] terão que levar ao INCRA, de 3 de março a 2 de abril, documentos que comprovem a titularidade ou posse pacifica da terra, plantas e memoriais descritivos com a correta localização geográfica dos imóveis rurais". ${ }^{13}$

Dessa forma, é preciso deixar claro que as verdadeiras posses das famílias camponesas ribeirinhas ou não na Amazônia não ocupam mais de 100 hectares, portanto, estes atos do INCRA foram para regularizar as grilagens das terras públicas do próprio INCRA que seus funcionários corruptos "venderam" para ao agrobanditismo.

Vale lembrar também, que apenas duas vezes na história do Brasil a "grande posse", ou melhor, a grilagem fora legalizada: a primeira vez na Lei de Terra de 1850, e, a segunda, pelo Decreto-Lei de 1931 de Getúlio Vargas.

ATO 6 - O espetáculo continua - O falso "nacionalismo" evocado no caso da compra 160 mil hectares de terra pelo empresário sueco Johan Eliasch

No dia 05 de junho de 2008, o mesmo do ano da MP 422, a Folha Online veiculou notícia na qual o ex-presidente do INCRA, Rolf Hackbart, havia determinado à

\footnotetext{
11 “A MP 422 legaliza e protege a floresta” (http://www.INCRA.gov.br).

12 “Assinada MP para regularização fundiária da Amazônia” (http://www.INCRA.gov.br).

13 "MDA e INCRA anunciam como será o recadastramento de imóveis rurais na Amazônia" (http://www.INCRA.gov.br).
} 
Superintendência do INCRA do Amazonas que abrisse procedimento investigativo para comprovar ou não a titularidade das terras em uma extensão de 160 mil hectares, que supostamente foram adquiridas em 2005, pelo empresário sueco Johan Eliasch. A notícia trazia as seguintes informações:

"se for constatada alguma irregularidade, o INCRA informa que pedirá o cancelamento dos registros na Justiça Federal. Para consultar a regularidade dos registros, a Procuradoria Federal Especializada enviará procuradores aos municípios de Manicoré (a 680 quilômetros de Manaus) e Itacoatiara (a 266 quilômetros) para verificar se os cartórios da região registraram imóveis em nome da madeireira Gethal Amazonas, comprada por Eliasch. Assessor do primeiro-ministro britânico Gordon Brown, o sueco é casado com a socialite brasileira Ana Paula Junqueira. Os dois deram entrevistas para jornais do mundo inteiro alardeando a compra de uma floresta na Amazônia ... Embora Eliasch tenha ficado famoso mundialmente por alardear a compra de um pedaço da Amazônia, não existem propriedades no local em seu nome. A suspeita é que ele tenha feito a compra em nome da madeireira ou de ONGs. 'Sabemos da existência de 47 imóveis rurais que pertenciam à Gethal nos municipios de Manicoré, Itacoatiara, Humaitá e Lábrea. Com o levantamento nos cartórios, poderemos verificar a possivel ilegalidade na venda das referidas terras', disse o procurador-chefe da PFE do INCRA no Amazonas, Carlos Alberto de Salles. Reportagem da Folha informa que o governo federal vai fechar o cerco à 'invasão estrangeira' na Amazônia. O objetivo é dificultar a compra de terras por empresas brasileiras controladas por capital estrangeiro ... De acordo com a reportagem, o alvo principal do governo é a Amazônia, onde estão $55 \%$ das propriedades do país registradas em nome de estrangeiros: são 3,1 milhões de hectares dos 5,5 milhões de hectares cadastrados no INCRA por pessoas físicas e jurídicas de outras nacionalidades. A presença estrangeira pode ser ainda maior, já que os proprietários não são obrigados a identificar a nacionalidade na hora do registro." ${ }^{14}$ (grifo meu)

Aproveitando a divulgação da notícia, o presidente Luiz Inácio apresentou sua visão "nacionalista" da questão:

"é impressionante a quantidade de gente [que se intromete no assunto]. De vez em quando eu fico pensando que a Amazônia é igual a vidro de água benta que tem na igreja: todo mundo que acha que pode meter o dedo ... É muita gente querendo dar palpite. Nós não podemos permitir que as pessoas tentem ditar as regras sobre o que tem de fazer na Amazônia. Palpite é o que não falta. O território é nosso. Mas os benefícios que estamos fazendo lá queremos compartilhar com humanidade pois queremos que todos respirem o ar verde produzido por nossas florestas." ${ }^{15}$

\footnotetext{
${ }^{14}$ http://www1.folha.uol.com.br/folha/brasil/ult96u409262.shtml - Acessado em 02/07/2011, às 18:27hs.

${ }^{15} \mathrm{http}: / /$ www1.folha.uol.com.br/folha/brasil/ult96u409187.shtml Acessado em 02/07/2011, às 18:29hs.
} 
E no embalo "nacionalista" o governo do PT tratou de definir conjunto de atos para recadastrar os imóveis rurais de estrangeiros e entidades sem fins lucrativos na Amazônia Legal. Os militares do governo acreditavam existir mais de 100 mil ONGs na região.(O ESTADO DE SÃO PAULO, 25/06/2008:A11) Mas, objetivamente, de que adiantou o tal recadastramento, senão criar obstáculos às ações das ONGs na Amazônia Legal.

ATO 7 - A ação da justiça, seu preço e a injustiça: o INCRA "devolve"as terras públicas da União e da reforma agrária ao agrobanditismo de Roraima

No dia 12/08/2008 o jornal O Estado de São Paulo em reportagem sobre o episódio envolvendo a retirada dos arrozeiros do agrobanditismo da grilagem de terras federais em Roraima, anunciava em manchete

\footnotetext{
"Lula promete doar terras da União para Roraima: um dia depois de o Supremo Tribunal Federal (STF) praticamente decidir pela manutenção em terras contínua da [Terra Indígena] Raposa Serra do Sol, o presidente Luiz Inácio Lula da Silva começou a discutir compensações para empresários e políticos afetados pela decisão. Em encontro no Palácio do Planalto, no início da noite de ontem, Lula disse que vai repassar 6 milhões de hectares de terras da União para o governo de Roraima, segundo o Senador Romero Jucá, um dos aliados dos arrozeiros que ocupavam terras indígenas ... O senador informou que no dia 28 de janeiro de 2009, Lula assinará o Decreto que repassará as terras da União para o Estado." (O ESTADO DE SÃO PAULO, 12/12/2008:A6.) (grifo meu)
}

Ou seja, o governo de Luiz Inácio nunca negou seu apoio incondicional ao agronegócio, mesmo quando agia com agrobanditismo, como foi o caso de Roraima. Assim, tratou logo de recompensá-los, e, de onde saiu a solução para o caso? É lógico que foi do INCRA do ex-presidente Rolf Rackbart. Terras do INCRA, quer dizer, da reforma agrária foram doadas ao Estado de Roraima para retribuir ao agrobanditismo dos arrozeiros sulistas daquele estado. Aliás, jornal O Estado de São Paulo, também noticiou o fato em 29/01/2009:

"O Presidente Luiz Inácio Lula da Silva assinou ontem um decreto e uma medida provisória que permitirão a transferência de 6 milhões de hectares de terras da União para Roraima - cerca de $25 \%$ da área do Estado ... A MP permite as doações de terras por razões que não apenas a reforma agrária - até hoje, esse era o único motivo para dispor das áreas." (O ESTADO DE SÃO PAULO, 29/01/2009:A8.) 
Foi exatamente o que aconteceu, em 28/01/2009, foi assinada a Medida Provisória $\mathrm{N}^{\mathrm{o}} 454$ pelo governo de Luiz Inácio e Guilherme Cassel, que foi convertida na Lei ${ }^{\mathrm{o}} 11.949$ de 17/06/2009. ${ }^{16}$ Assim, as terras da reforma agrária do INCRA foram transferidas para o governo de Roraima.

Mas, para terminar com festa mais este ato de dilapidação do patrimônio público e entrega das terras da reforma agrária do INCRA ao agrobanditismo de Roraima, quem esteve pessoalmente para acompanhar a assinatura do ato de transferência em Boa Vista/RR foi o ex-presidente do INCRA Rolf Rackbart acompanhado do ministro do MDA Guilherme Cassel. (O ESTADO DE SÃO PAULO, 23/05/2009:A22.) Três meses antes o governo de Luiz Inácio tinha assinado a MP 458, legislação mor da legalização da grilagem de terras na Amazônia Legal, como se verá no próximo ato. Entretanto, antes é necessário informar que o jornal O Estado de São Paulo de 07/03/2011, noticiou que

"acusado de invasão de 2.811 hectares de terras públicas nas cercanias de Boa Vista, em Roraima, o senador Mozarildo Cavalcanti (PTB-RR) tornou-se réu em ação de imissão de posse movida pelo governo do Estado. Segundo pedido de tutela antecipada, apresentado pela Procuradoria-Geral do estado, o senador apropriou-se de uma gleba que o governo destinou ao assentamento de agricultores ... Segundo o presidente do Instituto de Terras, Márcio Junqueira, o senador detém título definitivo de 1.600 hectares denominado TD Boqueirão, na gleba Murupu. Ele teria se apossado de mais 2.811 hectares e agregado à sua fazenda de forma irregular." (O ESTADO DE SÃO PAULO, 07/03/2011:A7.)

Assim, seguia no país o processo de grilagem das terras públicas da reforma agrária, este era apenas mais um exemplo entre muitos outros.

\section{ATO 8 - O alerta internacional e a conexão sul americana: o site da GRAIN, a} REAF e os Relatórios PCT IICA/NEAD do MDA/INCRA

Em outubro de 2008, o site mundial da Grain (uma organização internacional sem fins lucrativos, que trabalha apoiando camponeses, pequenos agricultores e movimentos sociais em suas lutas para conseguir sistemas alimentares baseados na biodiversidade e controlados comunitariamente) passou a publicar notícias e artigos referentes à apropriação de terras em todo mundo pelas empresas mundiais, particularmente aquelas que operam com o comércio de alimentos e pelos fundos de

\footnotetext{
${ }^{16}$ Ver a íntegra da Lei no 11.949 , de 17 de junho de 2009.
} 
investimentos e investidores privados. (www.grain.org) Inclusive, criou um site específico para veicular as notícias relativas à apropriação de terras por estrangeiros.(http://farmlandgrab.org/)

No primeiro texto divulgado, mesmo sem nenhum estudo prévio, o processo de aquisição e arrendamento de terras por pessoas, grupos, fundo ou empresas estrangeiras passou a ser abordado de forma imperativa como novo e de caráter mundial, ou seja, os dirigentes da GRAIN já tinham antecipadamente a explicação para o que estava acontecendo, uma espécie de explicação recusada por Raul Seixas em sua música "Metamorfose Ambulante", ou seja, "ter aquela velha opinião formada sobre tudo $^{\prime 17} .^{17}$ (grifo meu)

Assim, a GRAIN informou pela primeira vez, o fato da aquisição de terras por estrangeiros no mundo:

"as crises alimentar e financeira atual, combinadas, desencadearam um novo ciclo mundial de apropriação de terras. Os governos com 'insegurança alimentar', que dependem de importações para alimentar sua população, estão tomando rapidamente terras agrícolas em todo o mundo, onde produzem seus próprios alimentos fora do país. Corporações mundiais que comercializam alimentos e investidores privados, com fome de lucros em meio à profunda crise financeira, vêem o investimento em terras agrícolas estrangeiras como uma importante nova fonte de renda. Como resultado, férteis terras agrícolas são privatizadas e, cada vez mais concentradas." ${ }^{18}$ (grifo meu)

E mais, a GRAIN não ficou somente nessa assertiva, no texto decretou igualmente, sem estudo prévio algum, o fim da agricultura camponesa e do campo como modo de vida: "Ante a incapacidade de deter este processo, a apropriação de terras global poderia significar, em muitas partes do mundo, o fim da pequena agricultura e do campo como um modo de vida e subsistência."(16) (grifo meu)

A esse processo de aquisição e arrendamento de terras por estrangeiros, os textos em língua inglesa passaram a utilizar várias noções/conceitos: "farmland grab"; "land $\boldsymbol{g r a b}^{\prime \prime \prime}$ (AREZKI, DEININGER e SELOD, 2010; COTULA, VERMEULEN, LEONARD e KEELEY, 2009; KUGELMAN e LEVENSTEIN, 2010) ${ }^{19}$; "land

\footnotetext{
${ }^{17}$ SEIXAS, R. Metamorfose ambulante, in http://letras.terra.com.br/raul-seixas/48317/ Acessado em 18/07/2011 às 19:33hs.

${ }^{18}$ GRAIN, iSe adueñan de la tierra! El proceso de acaparamiento agrario por seguridad alimentaria y de negocios en 2008, in http://www.grain.org/briefings/?id=214 - Acessado em 18/07/2011 às 21:50hs.

${ }^{19}$ GRAIN, CGIAR joins global farmland grab in http://www.grain.org/articles/?id=52 - Acessado em 18/07/2011 às 18:10hs, e GRAIN, World Bank report on land grabbing: beyond the smoke and mirrors in
} 
grabbing (BRAUN, J. von, e R. MEINZEN-DICK. 2009; FIAN. 2010; SAUER, S. e LEITE, S. P. 2011). Lee MACKEY (2011) do Department of Planning, University of California, Los Angeles utiliza a noção de "foreignization of space”, (ZOOMERS, 2010), e, lembra também, que há o uso da noção "foreignization of land".(MACKEY, 2011:2)

Um texto de SAUER (2010) trouxe também, no título e no texto a expressão "land grabbing". Nele, com relação ao uso da noção "farmland grab", a crítica de SAUER (2010:29) em relação a NASSAR (2011) deve ser ampliada, pois, o uso da tradução "arresto de terras agrícolas" não cabe, porque a palavra arresto em português remete a seu uso no Direito onde tem o sentido de embargo. Também, SAUER e LEITE (2011:2) trabalharam com a noção "land grabbing", em texto apresentado na International Conference on Global Land Grabbing, quando eles procuraram ampliar a discussão, pois, era o próprio tema da conferência: "Esta expressão tem sido utilizada nos estudos sobre o campo, caracterizando um processo de apropriação de grande parte da terra pelo capital estrangeiro. Como MERLET (2010) lembra corretamente, este processo não pode ser reduzido apenas ao mecanismo de 'compra' da terra ("purchasing" land), o que pressupõe o funcionamento de um mercado de terras marcado pela compra e venda de propriedades rurais. Segundo o estudo solicitado pelo Comité Technique Foncier et Développement, estamos diante de um movimento de 'apropriação e concentração da terra - e recursos naturais - em larga escala' ("appropriation and concentration of land - and natural resources - in large scale") (Merlet, 2010). Outras instituições, tais como a Terra Internacional Coalition (ILC, 2009; TAYLOR e DOBRA, 2009) usam a expressão 'pressões comerciais sobre terra' (“commercial pressures on land”), que também pode restringir a compreensão do que estamos observando atualmente."( SAUER e LEITE, 2011:2). Já, o texto de FERNANDES (2011:77) optou pela expressão "land grabbing" e indica também, a versão "acaparamiento de tierras" para a língua espanhola, mas, como em sua bibliografia havia o texto de GLAUSER (2009), que utiliza a expressão "extranjeirización", fez por ela, sua opção.

É importante frisar que há pequenas diferenças tanto na língua inglesa como na portuguesa para as quatro noções. Assim, talvez a melhor formulação conceitual para "farmland grab", seja apropriação de terras agricultáveis. Para "land grab" talvez 
seja mais indicado apropriação de terras simplesmente. E, para a noção "land grabbing" a opção deve ser por grilagem de terras, embora o site farmlandgrab.org utilize na tradução para o português: neogrilagem legal de terras (GRAIN, 2010. Na língua francesa a noção é "l'accaparements de terres" e, em espanhol são duas as noções "acaparamiento de tierras" e "extranjeirización". Em português tem sido utilizada a noção/conceito de "estrageirização de terras"( FERNANDES, 2011; ALVIM, 2009), SAUER e LEITE (2010), etc. que é também, preferida pela mídia.

Com a finalidade de buscar respaldo internacional, o MDA/INCRA organizou a XX Sessão Nacional da Reunião Especializada sobre Agricultura Familiar do Mercosul (REAF) que ocorreu em Brasília entre 27 e 31/10/2008. Como parte da programação na tarde do dia 28, o ex-presidente do INCRA participou do seminário "Função Social da Propriedade - Concentração, Estrangeirização e Uso da Terra" realizado na sala de reuniões da Presidência do INCRA. O seminário contou também com a presença de José Antônio Dias Toffoli, ex-presidente da Advocacia Geral da União (AGU), e atual membro do Supremo Tribunal Federal (STF) que discutiu a proposta de modificação do marco legal de aquisição de terras por estrangeiros no Brasil. Também foi discutido durante o seminário a "problemática da estrangeirização" nos países do MERCOSUL ampliado (Brasil, Argentina, Paraguai e Uruguai e visões de Venezuela, Bolívia e Chile). Entre 22 e 30/11/2008, no Rio de Janeiro, ocorreu a X REAF Mercosul, quando o mesmo seminário foi realizado. Durante sua participação no seminário o ex-presidente do INCRA afirmou que "dentro deste contexto de várias crises mundiais - de energia, de alimentos, financeira - o acesso a terra é uma das condições para o desenvolvimento da América Latina". ${ }^{20}$ (grifo meu)

Dessa forma, a veiculação dos debates em nível governamental dos países sul americanos foi consolidando, no plano político e midiático nacional, a importância do tema no Brasil, acompanhado de sua amplificação no seio dos movimentos socioterritoriais e sindicais. Ao mesmo tempo, a noção de estrangeirização das terras no Brasil, ganhava seu "avant-première" em solo pátrio, pois já estava virando moda nos debates e textos da esquerda e da direita em nível mundial. ${ }^{21}$

Como produto do debate na X REAF (nacional e Mercosul), em 2009, o MDA/INCRA através do Núcleo de Estudos Agrários e Desenvolvimento Rural

\footnotetext{
${ }^{20} \mathrm{http}: / /$ www.mda.gov.br/portal/noticias/item?item_id=3588786 - Acessado 18/07/2011, às 21:34hs.

21 Ver site da Grain - http://www.grain.org - e, o arquivo com os artigos: http://farmlandgrab.org/date/?date=12-2008 - Acessado em 18/07/2011 às 21:45hs.
} 
(NEAD) encomendou dois relatórios técnicos sobre aquisição de terras por estrangeiros no Brasil. Um estudo sobre "Imóveis rurais sob propriedade de estrangeiros no Brasil" foi elaborado por PRETTO (2009), com o objetivo de "fornecer subsídios técnicocientíficos para obtenção e sistematização das informações sobre os imóveis rurais de propriedade de estrangeiros no Brasil e os processos, causas e efeitos da concentração no Brasil", a partir de "levantamento e sistematização preliminar de dados cadastrais do Sistema Nacional de Cadastro Rural do Instituto Nacional de Colonização e Reforma Agrária - SNCR INCRA."(PRETTO, 2009:3) O outro estudo foi sobre "Investimentos estrangeiros diretos e suas relações com os processos, causas e efeitos da concentração e estrangeirização das terras no Brasil", elaborado por ALVIM (2009) visando fornecer subsídios para compreender o processo e a quantidade de Investimento Estrangeiro Direto (IED) na agricultura e particularmente, na compra de terras. Este estudo visava procurar compreender à aquisição de terras pelas empresas nacionais de capital estrangeiro, que desde 1998, "estavam desobrigadas" de informar especialmente, o INCRA sobre as aquisições de terra.

O estudo de PRETTO (2009) foi elaborado

"a partir de uma solicitação feita pela Assessoria Internacional do Ministério do Desenvolvimento Agrário, o SNCR/INCRA realizou uma apuração especial, denominada Apuração Especial DM 009425. Este relatório, que foi extraído no dia 04 de junho de 2008, será denominado, a partir deste momento, Apuração Especial 2008/SNCR/INCRA ou AE2008/SNCR/INCRA. A AE2008/SCNR/INCRA contém 34.632 registros de imóveis rurais em nome de pessoas físicas ou jurídicas estrangeiras. Estes registros são classificados como minifúndios, pequenas, médias e grandes propriedades e montam, no seu total, a 4.037.667.60 (quatro milhões, trinta e sete mil, seiscentos e sessenta e sete hectares com seis mil metros quadrados) em áreas registradas em nome de estrangeiros. Estes registros estão datados desde o ano de 1909 até o ano de 2008. Deste total de registros apenas 414 registros que somam 9.006 (nove mil e seis hectares) não puderam ser utilizados para a realização deste estudo, em função de dois motivos: - da absoluta inexistência de informação acerca de área. Não constava nem o número de módulos fiscais nem a área em hectares; - ou em função de apresentarem a informação de data de forma negativa. Estes registros correspondem a $1,20 \%$ do total de registros e a $0,22 \%$ da área total dos registros existentes. Após a retirada destes 414 registros foi observado o perfil da concentração de terras registradas em nome de estrangeiros no Brasil. Os registros da AE 2008 SNCR/INCRA indicam que os minifúndios (até 1 módulo fiscal) e as pequenas propriedades (de 1 a 4 módulos fiscais) representam: - mais de $\mathbf{8 3 \%}$ dos registros ( $83.56 \%$ ) existentes em nome de estrangeiros no SNCR; - pouco mais de $\mathbf{1 6 \%}$ das áreas $(16,83 \%)$ de terras dos imóveis rurais registrados em nome 
de estrangeiros no Brasil; Por outro lado, as médias propriedades (de 4 a 15 módulos fiscais) e as grandes propriedades (mais de 15 módulos) fiscais representam: - pouco mais de $16 \%$ dos registros $(16,43 \%)$ e, - mais de $\mathbf{8 3} \%$ das áreas $(83,17 \%)$ de terras dos imóveis rurais registrados em nome de estrangeiros no Brasil; Em consonância com o texto do Termo de Referência que dá origem a este estudo diz que "De acordo com a decisão da VIII Reaf, realizada em outubro de 2007, as suas Seções Nacionais constituirão equipes de trabalho integradas pelo setor público e as organizações da Agricultura Familiar para elaborar documentos com o objetivo de obter e sistematizar as informações sobre os processos, causas e efeitos da concentração e estrangeirização das terras e propor medidas alternativas. Desta forma, e em função dos objetivos gerais estabelecidos pela REAF e pela Assessoria Internacional do MDA, que são estudar a concentração de terras em nome de estrangeiros no Brasil e nos países do Mercosul, foram realizados dois recortes metodológicos. O primeiro deles, passou a considerar, para análise mais detalhada, apenas médias e grandes propriedades, classes de imóveis rurais mais claramente relacionados ao tema da concentração fundiária. Desta forma, o centro da atenção do estudo passou a ser o conjunto de 5.627 (cinco mil seiscentos e vinte e sete) registros classificados como médias e grandes propriedades registradas em nome de estrangeiros no SNCR, conforme a AE 2008 SNCR/INCRA. Este conjunto soma um montante de 3.357.741,68 hectares (três milhões, trezentos e cinqüenta e sete mil setecentos e quarenta e um hectares com seis mil e oitocentos metros quadrados). Após este recorte, que concentra as atenções deste estudo nas médias e grandes propriedades foi realizada a análise da presença e concentração de médias e grandes propriedades registradas em nome de estrangeiros nas 27 unidades federativas do Brasil. Esta análise permitiu observar que apenas 11 (onze) unidades federativas concentram mais de $91 \%$ das médias e grandes propriedades registradas em nome de estrangeiros (...)" (PRETTO, 2009:10/12) (grifo meu)

Os onze estados destacados no estudo foram, pela ordem: MT, MS, SP, BA, MG, GO, PR, PA, TO, AM e RS. Já,

"o segundo recorte refere-se aos municípios destas 11 unidades federativas. Nestas onze unidades federativas existem 1.396 municípios com presença de médias e grandes propriedades registradas em nome de estrangeiros. Destes, apenas 124 contém pelo menos $50 \%$ da área de médias e grandes propriedades registradas em nome de estrangeiros, (...) Do ponto de vista da participação relativa destas unidades federativas e destes 124 municípios, que serão nominados na parte 2 deste estudo, temos a seguinte situação: 1 Estas 11 (onze) unidades federativas contêm mais de 91\% da área total terras registradas como médias e grandes propriedades em nome de estrangeiros em todo o Brasil. 2 - Estes 124 (cento e vinte e quatro) municípios contêm mais de $52 \%(52,19 \%)$ da área total terras registradas como médias e grandes propriedades em nome de estrangeiros no total das onze UFs selecionadas. 3 - Mais que isto: sozinhos, este 124 municípios contêm mais de $47 \%$ da área de todas $(47.53 \%)$ as médias e grandes propriedades registradas em 
nome de estrangeiros em todas as 27 unidades federativas do Brasil. Ou seja, nestes 124 municípios está localizada praticamente a metade da área de médias e grandes propriedades registradas em nome de estrangeiros no Brasil, o que justifica o recorte metodológico realizado." (PRETTO, 2009:13/14) (grifo meu)

Este estudo de PRETTO (2009) reuniu mais 100 planilhas de dados relativos à terras de estrangeiros, todas com suas importâncias relativas, porém, talvez o que de fundamental o estudo não tem, era o quadro da distribuição territorial dos imóveis rurais e sua participação percentual na área total do município, pois este é um dos requisitos legais principais da Lei $\mathrm{n}^{\mathrm{o}}$ 5.709/71, em particular, do artigo 12 - A soma das áreas rurais pertencentes a pessoas estrangeiras, físicas ou jurídicas, não poderá ultrapassar a 1/4 (um quarto) da superficie dos Municipios onde se situem, comprovada por certidão do Registro de Imóveis, com base no livro auxiliar de que trata o art. 10.

Mas, como nem o INCRA que é órgão responsável pelo cumprimento da lei, o faz, a metodologia escolhida por PRETTO (2009) foi montar sua equivocada análise estatística apenas com os médios e grandes imóveis rurais, deixando de lado, o total dos imóveis de estrangeiros de cada município. Ou seja, privilegiou a análise da concentração em detrimento do total da área municipal. Portanto, os exemplos, de municípios que excederam o limite legal que retirei de seu estudo, referem-se apenas à área dos grandes e médios imóveis de estrangeiros, o que quer dizer, que certamente, poderá haver mais municípios com área de terras de estrangeiros que já excederam o limite legal, sem que INCRA sequer tivesse tomado conhecimento da questão.

Assim, como se pode ver, o fato principal que o estudo deveria ter revelado, não foi destacado nem no relatório e muito menos pelo INCRA/MDA, que é o órgão responsável pelo cumprimento da lei. O estudo por sua vez, mesmo com a metodologia adotada, deixou de informar ao INCRA que já há no Brasil, quatro municípios para os quais não se está cumprindo o artigo 12 da Lei $n^{\circ}$ 5.709/71, pois, o INCRA, permitiu que fossem lançados a registro, inclusive em seu cadastro, um total de terras de estrangeiros que superam os $25 \%$ do limite máximo municipal. É possível até, que entre esses municípios hajam aqueles que os estrangeiros já tinham recebido a "autorização" para registro durante a ditadura militar.

Dois desses municípios nos quais a área dos grandes e médios imóveis rurais excedem o limite legal estão no estado de São Paulo. Um é o município de Magda que possui área territorial de 31.208,5 hectares, porém, os dois imóveis rurais de estrangeiros somam área total de $18.548,6$ hectares, ou seja, $59,4 \%$ da superfície 
municipal. O outro município é Campo Limpo Paulista, que por sua vez, possui área territorial de 8.004,8 hectares, porém, tem 22 imóveis rurais de estrangeiros, mas, apenas um está entre os médios e grandes imóveis privilegiados, metodicamente no estudo de PRETTO (2009), e tem a área total de 3.298,4 hectares, ou seja, 41,2\% da superfície municipal. Isto quer dizer que, a área de terras de estrangeiros no município é maior ainda, pois faltam outros 21 imóveis classificados como pequenos e minifúndios.

Os outros dois municípios estão na Bahia. Um é o município de Eunápolis que possui área territorial de 119.669,5 hectares, porém, tem 76 imóveis rurais de estrangeiros, sendo que a soma dos 53 imóveis rurais grandes e médios chegam a uma área total de $46.665,48$ hectares, ou seja, $39,0 \%$ da superfície municipal. $O$ outro município, por ironia da história do Brasil, é Santa Cruz Cabrália, que por sua vez, possui área territorial de 155.079,1 hectares, e tem 148 imóveis rurais de estrangeiros, porém, 67 imóveis rurais de estrangeiros médio e grandes somam a área total de 45.811,2 hectares, ou seja, $29,54 \%$ da superfície municipal. Certamente, a área de estrangeiros nestes dois municípios é maior do que aquelas que o estudo registrou, pois faltam também, os pequenos e os minifúndios.

Estes quatro exemplos, são indicadores de que pode haver mais municípios brasileiros, nos quais já se tenha excedido o limite legal das terras de estrangeiros. Certamente, é aqui que deveria estar concentrado os esforços do INCRA para com as terras de estrangeiros, e não, a farsa do "novo escândalo" das aquisições recentes.

Em agosto de 2010, dias após o último parecer mais restritivo da AGU, o INCRA apresentou estatísticas cadastrais até então inéditas, sobre à aquisição de terras por estrangeiros no Brasil e sobre imóveis pertencentes à pessoas jurídicas nacionais, referentes ao período entre 1972 e 2008.

A análise desses dados revelam praticamente o inverso da tese defendida pelo ex-presidente do INCRA, pois, primeiro, o número absoluto dos imóveis registrados em

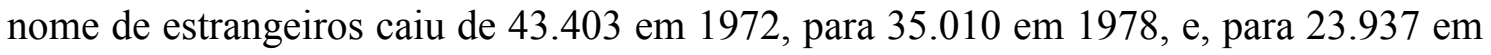
1992. Depois, em 1998 há um pequeno aumento para 27.274; outro aumento para 33.219 em 2007; e um pouco mais em 2008, quando atingiu 34.591. Mas, em 2009 o número volta a cair para 34.371. Quanto à área ocupada, a evolução no mesmo período, revela um quadro parecido com aqueles referentes ao número de imóveis. Em 1972 a área ocupada pelos imóveis era de 7,161 milhões de hectares e caiu para 6,865 em 1978. 
Em 1992 a queda foi maior chegando a 2,615 milhões de hectares. Deste ano em diante, o crescimento foi pequeno, porém, constante: em 1998 a área era de 3,033 milhões; 2007 igual a 3,833; em 2008 foi de 4,039, em 2009 atingiu 4,348 milhões e em 2010 chegou a 4,500 milhões de hectares. Logo, os dados de 2009, embora em processo de crescimento, mostram a insignificância territorial das terras em poder de estrangeiros no Brasil, face as disposições legais vigentes, ou seja, ocupam apenas 0,53\% do território brasileiro. Os gráficos 01 e 02 a seguir, mostram a evolução dos dados.

\section{Gráfico 01}

Brasil - Número de Imóveis Registrados em Nome de Estrangeiros

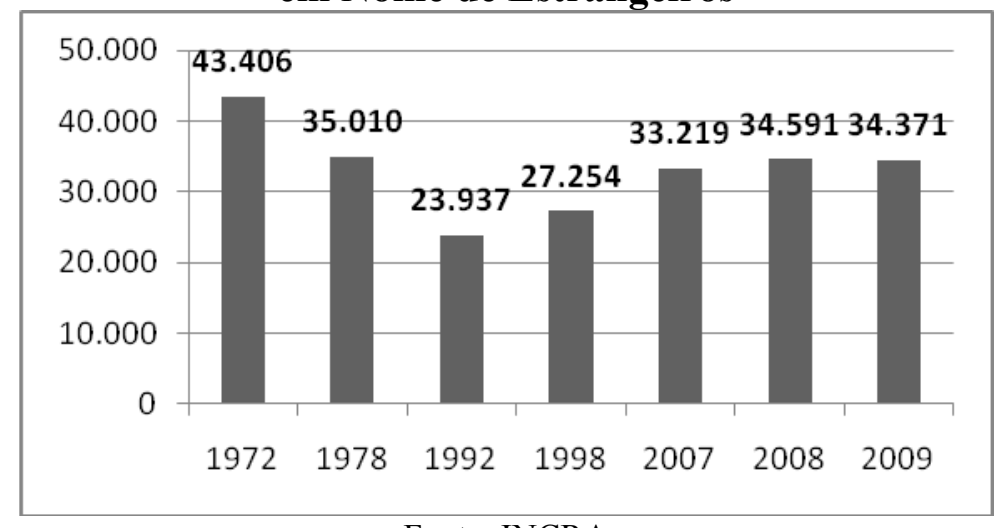

Fonte: INCRA

Gráfico 02

Brasil - Área Total dos Imóveis

Registrados em Nome de Estrangeiros

(em milhões de hectares)

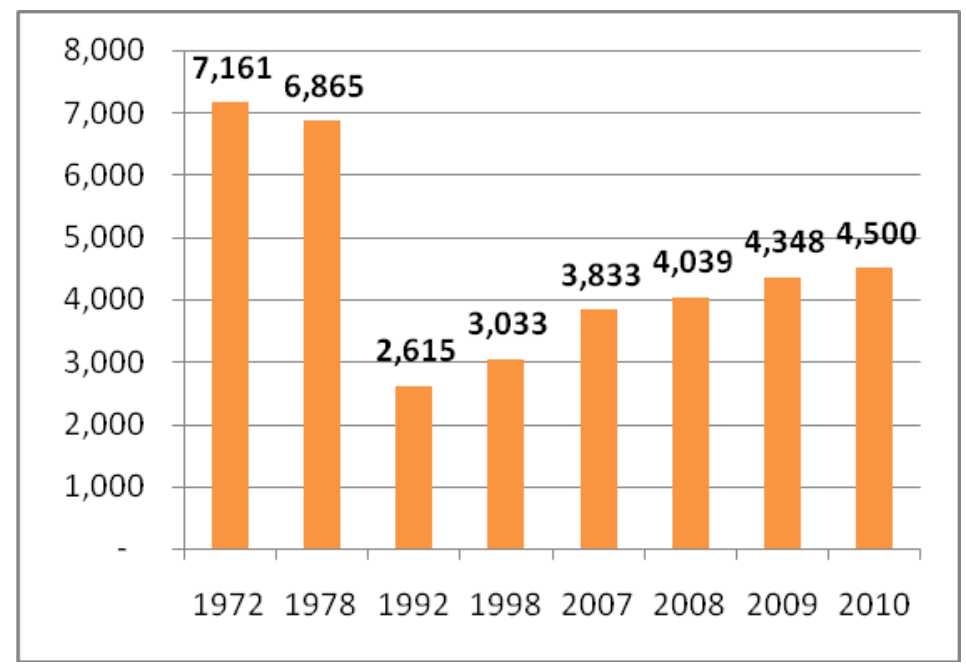

Fonte: INCRA 
Mas, o ex-presidente do INCRA Rolf Rackbart, apegou-se ao comportamento dos dados relativos à evolução do número e área ocupada pelos imóveis das pessoas jurídicas nacionais, pois, estariam sendo "laranjas" das empresas estrangeiras. Esta assertiva estava prisioneira da ênfase na divulgação dada ao percentual de $95 \%$ de seu crescimento entre 1998 e 2008. (VALOR ECONÔMICO, 26/08/2010:A2). Entretanto, quando se observa o número absoluto que este percentual representa, verifica-se que é de 64 mil empresas nacionais a mais no período entre 1998 e 2008, e que de per si pode ser julgado elevado. E, quando ele é cruzado com a área ocupada em hectares, em termos percentuais torna-se, ainda mais elevado, pois, alcançou 121\%. Inclusive, podendo ser considerado elevadíssimo, quando olhado os valores absolutos, pois, passou de 80 milhões de hectares em 1998 para 177 milhões em 2008. A diferença de crescimento no mesmo período, foi de 97 milhões de hectares. Esse crescimento expressivo torna-se mais emblemático quando se verifica sua evolução. Em 1972, o número de imóveis das pessoas jurídicas nacionais era de 27.575 imóveis rurais. Passou para 42.498 em 1978; depois para 50 mil em 1992; chegou a 67 mil em 1998 e 131 mil em 2008. Já a área ocupada era de 34 milhões de hectares em 1972; passando para 60 milhões em 1978; manteve-se em 60 milhões em 1992; depois para 80 milhões em 1998 e alcançando 177 milhões em 2008. Os gráficos 03 e 04 a seguir, mostram a evolução dos dados.

\section{Gráfico 03}

\section{Brasil - Número de Imóveis Registrados} por Pessoa Jurídicas Nacionais

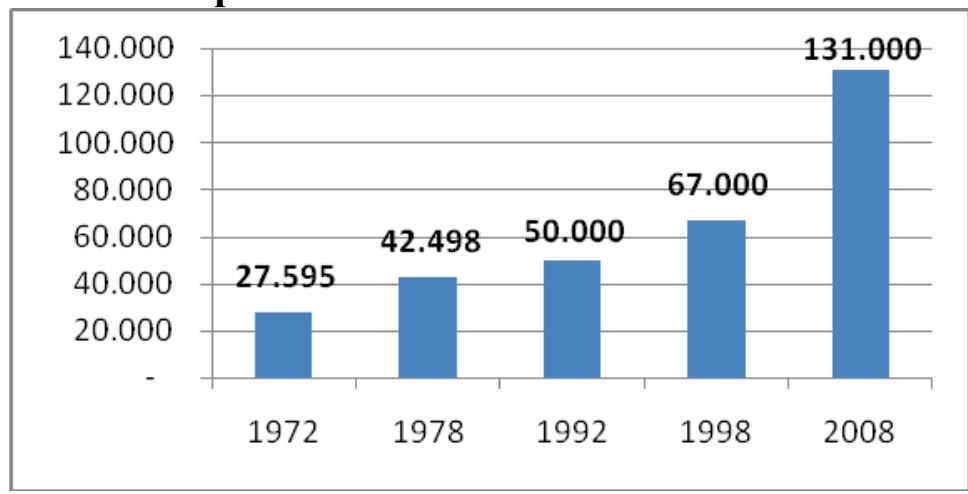

Fonte: INCRA 


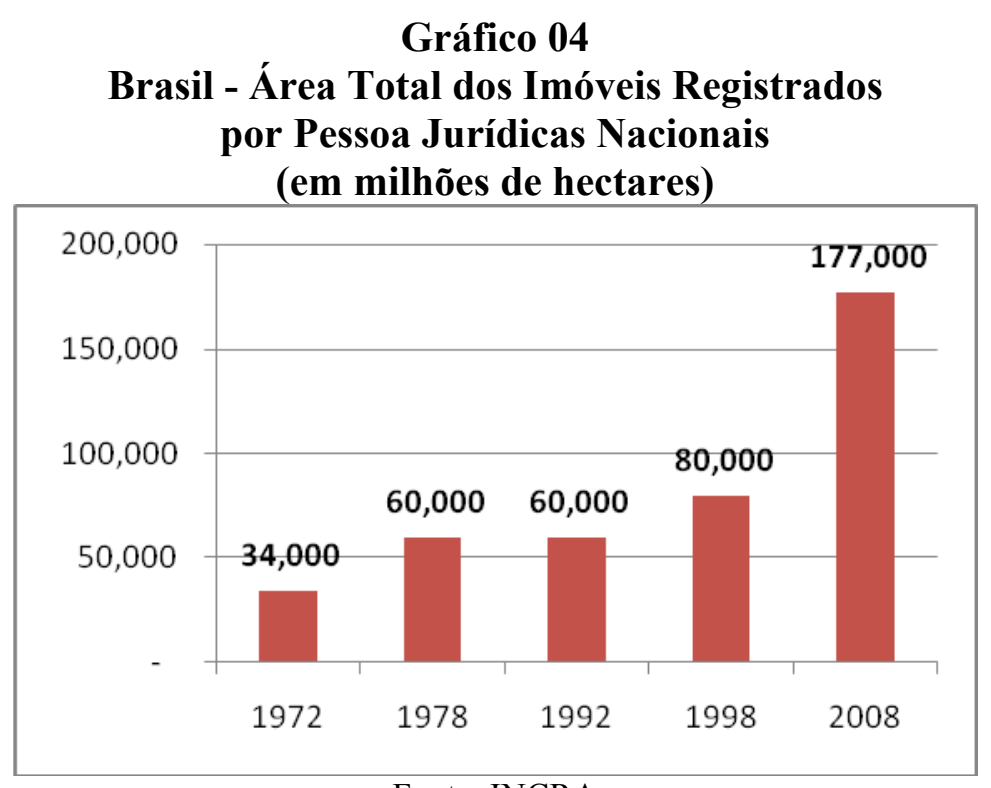

Fonte: INCRA

Certamente, se essa diferença expressiva fosse de fato, integralmente de pessoas jurídicas nacionais "laranjas", o ex-presidente do INCRA poderia externar preocupação, pois, estava-se diante um escândalo muito maior do que aquele da ditadura militar. Porém, ainda assim, o limite máximo estipulado pela Lei 5.709/71, ainda não estaria sendo atingido. Mas, essa é apenas uma hipótese, portanto, um construção idealizada, sem provas objetivas suficientes para demonstrá-la, exceto, se o instrumento teórico de interpretação também, estiver fundado na máxima de Raul Seixas na música Metamorfose Ambulante já citada, ou seja, parece que Rolf Hackbart também já tinha "aquela velha opinião formada sobre tudo". Provavelmente, idealizou sua hipótese munido das muitas teorias da conspiração ou do imperialismo, que não são mais suficiente para compreender o capitalismo mundializado do Século XXI. De qualquer forma, toda sua interpretação deriva apenas de suposições, e, como ex-presidente do INCRA, para melhor compreender a questão deveria ter feito um novo recadastramento nacional dos imóveis rurais, como se fez em 1992. Ou então, fazer a análise estatística por amostragem ou não, de outras variáveis existentes no Sistema Nacional do Cadastro Rural (SNCR) dessas novas empresas que entraram no cadastro entre 1998 e 2008, tais como: contrato social, atividades econômicas predominantes segundo a localização dos imóveis cruzadas com o tempo de existência dessas empresas nacionais, etc. Aliás, o caso da Stora Enso no Rio Grande do Sul já era exemplo objetivo e consistente, pois, constituiu e usou "empresa laranja" para burlar a legislação brasileira, e, a tragédia é que apesar disso, conseguiu o registro de suas terras.(O EESTADO DE SÃO PAULO, 
05/03/2008:A8.) Mas, não foi o que aconteceu com o ex-presidente do INCRA, e, é aqui que está uma das minhas questões interpretativas deste texto em relação aos dados e ao seu comportamento como o mais novo "fabricador" de um factóide sobre um pretenso escândalo sobre à aquisição de terras por estrangeiros no Brasil no final da primeira década do Século XXI.

Aliás, é preciso registrar que a hipótese de Rolf Rackbart, foi construída também, a partir do relatório técnico NEAD/MDA encomendado a Augusto Mussi ALVIM (2009) da PUC/RS, sobre os Investimentos Estrangeiros Diretos (IEDs) no setor agropecuário e sua relação com à aquisição de terras por estrangeiros no Brasil. $\mathrm{O}$ relatório mostrou que nos últimos dez anos, as multinacionais do ramo de alimentos transferiram 46,9 bilhões de dólares para o país. E, destacou que em 2002, os estrangeiros destinaram 104 milhões de dólares para a compra de terras, elevando a quantia para 548 milhões de dólares em 2008, ou seja, 427\% de crescimento. (VEJA, 18/05/2011:139) Ou seja, novamente usou-se o percentual de crescimento elevado para alardear-se equivocadamente, o grau de significância de um fenômeno econômico. Entretanto, em primeiro lugar, quando se analisa a relação entre a quantia destinada para aquisição de terras e o total dos investimentos, a conclusão pode ser oposta, ou seja, os investimentos na aquisição de terras representaram em 2002, apenas 2,4\% do total de investimentos de 4.332,4 milhões de dólares. Sendo que em 2008, a relação foi de $6,1 \%$ do total de 8.977,5 milhões de dólares. Mesmo que se evoque o crescimento destes novos percentuais, os $93,9 \%$ dos investimentos aplicados fora do mercado de terras em 2008, é que representam a essência do fenômeno analisado, e não o contrário. E, mais, fazendo-se o cálculo indireto da quantidade de terras que esses investimentos diretos poderiam ter atingido em 2002, para um preço médio por hectare de terra de pastagem em Mato Grosso de R\$1.211,00 e um dólar médio de R\$2,92, comprar-se-ia 108 mil hectares. Já para um preço médio por hectare de R 2.219,00 e um dólar médio de $\mathrm{R} \$ 1,70$, daria para adquirir no máximo 341 mil hectares de terras no país, em 2008. Como o relatório de ALVIM, analisa dados até o ano de 2008, tomando-se em 2009, o IED total na agropecuária e na produção florestal, ou seja, sem separar-se aquele aplicado em terras, ele foi de 419,72 milhões de dólares, logo, para um dólar médio de $\mathrm{R} \$ 2,00$ e para um preço médio por hectare de $\mathrm{R} \$ 2.554,00$, este investimento estrangeiro total, permitir-se-ia comprar 328 mil hectares. Em 2010, para um IED na agropecuária e na produção florestal também total de 652 milhões de dólares, e, para um 
dólar médio de $\mathrm{R} \$ 1,76$ e para um preço médio por hectare de $\mathrm{R} \$ 2.789,00$, este investimento estrangeiro permitir-se-ia comprar 411 mil hectares.

Assim, se a média de crescimento anual no período fosse o resultado da variação entre os anos extremos, e, por hipótese, todos os IEDs aplicados em aquisição de terras, seria possível adquirir um total de 2,322 milhões de hectares entre 2002 e 2010, equivalentes a $0,27 \%$ da superfície do país. E inclusive, supondo-se que foi todo aplicado em pessoas jurídicas nacionais "laranjas", somando-se ao total de terras de estrangeiros legalmente presente no cadastro do INCRA em 2010, chegar-se-ia ao total de 6,822 milhões de hectares, ou, $0,80 \%$ do território brasileiro.

E mais, se o mesmo ritmo de crescimento fosse mantido, chegar-se-ia em 2020 com o total de 10,468 milhões de hectares sob controle de estrangeiros, ou seja, 1,23\% do país. Inclusive, se as mesmas condições de crescimento se mantivessem, em 2030, as terras de estrangeiros seria de 19,808 milhões de hectares, ou, 2,33\% do território brasileiro. E, mesmo que se alegue que este ritmo de crescimento entre 2002 e 2010 foi muito alto, e se ele fosse mantido, o limite legal (25\%) somente seria atingido no ano de 2.111.

Aliás, o ex-presidente do INCRA Rolf Rackbart e aqueles que acreditaram em sua farsa, particularmente os intelectuais, esqueceram-se propositalmente de que o limite legal imposto pela Lei $\mathrm{n}^{\circ} 5.709 / 71$, é de que os estrangeiros podem adquirir até um quarto da área do país (artigo 12), ou seja, 212,869 milhões de hectares do território brasileiro.

Portanto, os argumentos do relatório de ALVIM (2009) são insuficientes para sustentar a hipótese do ex-presidente do INCRA em relação à questão. $\underline{\text { Na realidade, } \mathbf{0}}$ que está por trás da farsa do "novo escândalo" sobre à aquisição de terras por estrangeiros, é a grilagem das terras públicas, e a ação da banda podre dos funcionários do INCRA, para legalizá-la, via contra-reforma agrária no governo Luiz Inácio (MPs 422 e 458), e agora, de Dilma Rousseff, se ela permitir.

A prova cabal desse argumento que sustento neste texto, está nas evidências dos novos números gerais da estrutura fundiária brasileira, divulgados pelo INCRA, para esse período. Uma primeira análise dos dados da Estatística Cadastral - Situação Jurídica, que o órgão elaborou em 2010, em termos totais do país, mostra que a base de dados validados do SNCR, cresceu em número de imóveis 20,8\%, e em área ocupada $36,7 \%$ entre 2003 e 2010, sem que nada de excepcional, significativo ou mesmo estrutural, tenha ocorrido no campo brasileiro. Este fato por si só, já permite levantar suspeita sobre esse crescimento que os dados indicam, principalmente, porque é no 
Cadastro que se concentra a maior parte da banda podre dos funcionários corruptos do INCRA. Mesmo assim, quando se analisa sua distribuição pela condição jurídica e pela classificação fundiária, esse aumento, principalmente na área ocupada, aparece concentrado na grande propriedade em geral, com mais de 104 milhões de hectares $(67,8 \%)$ sendo que a grande propriedade improdutiva abocanhou desse total, 94,7 milhões de hectares $(61,7 \%$ desse crescimento). Inclusive, quando se verifica a participação dos diferentes tipos de propriedades cruzadas com a situação jurídica dos imóveis, esse crescimento da área ocupada na base cadastral do SNCR, concentrou $45,4 \%$ entre os que se apresentam como proprietários, mas, $24 \%$ desse percentual anterior, ou seja, mais do que a metade, era de grandes propriedades griladas.

E mais, a maior parte desse crescimento das grandes propriedades griladas se deu nos estados da Amazônia Legal, onde o MDA implanta o Programa Terra Legal, derivado das Medidas Provisórias 422 e 458.

Dessa forma, é possível concluir que nesses seis anos que separam as duas séries estatísticas, a prática rentista da burguesia capitalista brasileira, tenha continuado seu ritual histórico de fazer da apropriação da privada da terra pública através da grilagem e da corrupção nos órgãos públicos, sua forma de acumulação original e também, da produção do capital, na melhor estirpe estudada por Rosa de LUXEMBURG na obra "A Acumulação do Capital".

Portanto, é quase impossível que a hipótese do ex-presidente do INCRA sobre o crescimento das empresas nacionais a partir de "empresas laranjas" de estrangeiros, tenha qualquer fundamento no campo brasileiro. Ao contrário, a maioria delas é mesmo de brasileiros, que historicamente, sempre usaram da grilagem de terras públicas como meio de formar sua base patrimonialista em terra, no capitalismo monopolista rentista nacional. Mesmo que no futuro, possam até vender parte delas para estrangeiros, para poder realizar a apropriação da renda capitalizada da terra e por conseguintemente, realizar a função de reserva de valor que a propriedade capitalista da terra também contém.

Como se pode verificar, todos os dados apresentados, revelam a insignificância atual da extensão territorial dos imóveis rurais de estrangeiros no Brasil, portanto, é preciso repetir, revelam que esse "novo escândalo" da aquisição de terras por estrangeiros adquiriu mesmo, a característica de farsa para encobrir outros fatos políticos que o governo de Luiz Inácio não quis explicitar. Entre eles estão a grilagem das terras públicas, a contra-reforma agrária em marcha, particularmente na 
Amazônia Legal, e a retirada da agenda política da reforma agrária como política pública de promoção do desenvolvimento econômico e social e de construção da soberania alimentar do país.

ATO 9 - A encenação teatral continuou: a contra-reforma agrária à todo vapor e o governo de Luiz Inácio manda ao Congresso Nacional a Medida Provisória 458, lei mor da grilagem de terra na Amazônia Legal

Depois da conversão da MP 422 em Lei no 11.763 de 01/08/2008, a banda podre dos funcionários do INCRA irmanados com a Democracia Socialista (DS) no MDA, foram mais longe, e propuseram, em 2009, a Medida Provisória $n^{\mathbf{o}} 458$ de 10/02/2009, que dispunha sobre a regularização fundiária das ocupações incidentes em terras situadas em áreas da União, no âmbito da Amazônia Legal, alterando novamente a Lei $n^{\circ} 8.666 / 93$, e as Leis 6.015 , de 31/12/73, 6.383, de 07/09/76, e 6.925, de 29/06/81. Ao contrário, da MP 422, a MP 458 permitia inicialmente, a regularização de área pública grilada até 2.500 hectares, além de estender a ação para as áreas da faixa de marinha. Esta MP foi convertida na Lei ${ }^{0} 11.952$ de 25/06/2009, e, apenas não foi aprovada pelo Congresso Nacional a extensão da legalização aos 2.500 hectares, permanecendo os 1.500 hectares da medida provisória anterior.

O pressuposto político e jurídico da MP 458, e também da MP 422, sempre foi a implantação do processo de regularização fundiária na Amazônia Legal. E que, somente com ela é que este processo poderia ser realizado, o que não corresponde à verdade dos fatos e dos instrumentos legais vigentes. O país já possuía instrumentos legais que permitiam a legitimação das posses segundo os princípios constitucionais vigentes. Entre estes instrumentos legais estão os artigos 188 e 191 da Constituição Federal de 1988:

“Art. 188. A destinação de terras públicas e devolutas será compatibilizada com a política agrícola e com o plano nacional de reforma agrária.

$\S 1^{\circ}$ - A alienação ou a concessão, a qualquer título, de terras públicas com área superior a dois mil e quinhentos hectares a pessoa fisica ou jurídica, ainda que por interposta pessoa, dependerá de prévia aprovação do Congresso Nacional.

$\S 2^{\circ}$ - Excetuam-se do disposto no parágrafo anterior as alienações ou as concessões de terras públicas para fins de reforma agrária."

"Art. 191. Aquele que, não sendo proprietário de imóvel rural ou urbano, possua como seu, por cinco anos ininterruptos, sem oposição, área de terra, em zona rural, não superior a cinqüenta 
hectares, tornando-a produtiva por seu trabalho ou de sua família, tendo nela sua moradia, adquirir-lhe-á a propriedade.

Parágrafo único. Os imóveis públicos não serão adquiridos por usucapião."

Também faz parte da legislação relativa à regularização fundiária a Lei $\mathrm{n}^{\circ} 6.383$ de 07 de dezembro de 1976, particularmente, o artigo 29 que trata dos ocupantes das terras públicas:

"Art. 29 - O ocupante de terras públicas, que as tenha tornado produtivas com o seu trabalho $e$ o de sua família, fará jus à legitimação da posse de área contínua até 100 (cem) hectares, desde que preencha os seguintes requisitos:

I - não seja proprietário de imóvel rural;

II - comprove a morada permanente e cultura efetiva, pelo prazo mínimo de 1 (um) ano.

$\S 1^{\circ}$ - A legitimação da posse de que trata o presente artigo consistirá no fornecimento de uma Licença de Ocupação, pelo prazo mínimo de mais 4 (quatro) anos, findo o qual o ocupante terá a preferência para aquisição do lote, pelo valor histórico da terra nua, satisfeitos os requisitos de morada permanente e cultura efetiva e comprovada a sua capacidade para desenvolver a área ocupada.

$\S 2^{\circ}$ - Aos portadores de Licenças de Ocupação, concedidas na forma da legislação anterior, será assegurada a preferência para aquisição de área até 100 (cem) hectares, nas condições do parágrafo anterior, $e$, o que exceder esse limite, pelo valor atual da terra nua.

$\S 3^{\circ}$ - A Licença de Ocupação será intransferivel inter vivos e inegociável, não podendo ser objeto de penhora e arresto."

Assim, estas alterações na dimensão das áreas a serem regularizadas, estabelecendo a garantia da preferência nos processos licitatórios aos grileiros, vinha sendo buscadas pela banda podre dos funcionários do INCRA, porque o governo atual já tinha feito uma aliança com o agronegócio, entregando assim, ilegalmente estas terras públicas para os grileiros na Amazônia Legal. E mais, o INCRA nunca propôs uma ação de reintegração de posse para recuperá-las, ao contrário, recebeu e chancelou em seus protocolos "pedidos dos grileiros para adquirirem-nas através de processo de alienação", ou seja, através da regularização fundiária. Na SR-01 de Belém no Pará no final do ano de 2004, estes pedidos eram mais de 16.860. E, somente nas 15 glebas da unidade avançada do Cachimbo havia mais de três mil processos envolvendo pedidos com áreas superiores a 300 hectares. O INCRA já possuía em seu cadastro o georreferenciamento de grande parte destas áreas griladas pretendidas, e que a MP 458 se propôs a regularizar. $\mathrm{O}$ recurso que os grileiros utilizarão para adquirir áreas maiores do que o limite constitucional de 1.500 hectares se fará através do uso de "posseiros 
laranjas", ou do nome de vários membros da família que nunca sequer pisaram naquelas terras.

Assim, a MP 458 transformou a ilegalidade criminosa da apropriação privada das terras públicas federais na Amazônia Legal, ou seja, a grilagem, em "irregularidade passível de regularização" (SIC).

Outra aberração jurídica da MP 458 refere-se ao artigo $2^{\circ}$, que contrário a qualquer manual acadêmico sobre a questão agrária, igualou em direitos o grileiro e o posseiro. O posseiro tem pela Constituição Federal de 1988, o direito à legitimação da posse, como informa o artigo 191 já citado anteriormente. Entretanto, este artigo da MP criou a figura da "ocupação indireta: aquela exercida somente por interposta pessoa", como se fosse dotada dos mesmos direitos daquela explicitada na ocupação direta. Trazia portanto, nestas noções a idéia de posse direta e posse indireta, ambas consagradas no direito das coisas na jurisprudência do país. Na realidade, tudo indica que no caso dos grileiros se está diante de uma posse injusta e clandestina porque contrária ao ordenamento jurídico existente, ao contrário do que ocorre com o posseiro cuja posse tem respaldo na Constituição de 1988. Cabe destacar também, que o parágrafo único do artigo 191 desta mesma Constituição indica que os imóveis públicos não serão adquiridos por usucapião.

Entre as noções contidas neste artigo $2^{\circ}$ há também a figura da "exploração indireta: atividade econômica exercida em imóvel rural, por meio de preposto ou assalariado". Assim, igualava-se o grileiro ao posseiro; pois em geral, o grileiro não ocupa de forma direta as terras, mas sempre usa de prepostos, ou de "laranjas". Entretanto, é preciso insistir que grileiro não é posseiro. E por fim, incluíram também entre as noções aquela relativa à "cultura efetiva, a exploração agropecuária, agroindustrial, extrativa, florestal, pesqueira" etc. Assim, juntaram nesta noção às atividades típicas dos posseiros, aquelas dos grileiros, visando, pois, igualar as atividades típicas da grilagem que consubstanciam crimes e o direito de posse e as atividades próprias dos posseiros. Dessa forma, aparece explicitamente a outra intenção da MP 458 igualar em direitos posseiros e grileiros. Dessa forma, os posseiros ancorados nos artigos $5^{\circ}$ e $6^{\circ}$, estão qualificados pelas suas características da posse expressa no artigo 191 da Constituição Federal de 1988, ou seja, pelas noções da ocupação direta e da exploração direta. Enquanto isso os grileiros foram contemplados pelo artigo 7 da MP 458 (Lei n ${ }^{\circ} 11.952$ de 25/06/2009). 
Em função desta MP 458, outro ponto favorável à grilagem foi aberto, pois, o Cadastro do INCRA tinha registrado em outubro de 2003, época da elaboração do II Plano Nacional de Reforma Agrária, um total de imóveis classificados com posses e grilos de 42,2 milhões de hectares, mas a exposição de motivos que acompanhou a MP 458 indicava a regularização de 67,4 milhões de hectares. Mesmo se somado a este total os imóveis que possuíam áreas registradas e posses/grilos, que em 2003 era de 3,2 milhões de hectares, não se atingirá o total indicado na MP. Isto quer dizer que o MDA vai regularizar inclusive, áreas novas griladas embora o artigo $5^{\circ}$ inciso II indique que elas devem ser anteriores a $1^{\circ}$ de dezembro de 2004.

Entre estes imóveis classificados como posses e grilos estavam 211 mil $(69,9 \%)$ de minifúndios, ocupando 8,3 milhões de hectares (19,8\%). Além dos minifúndios há 70 mil pequenas propriedades $(23,4 \%)$ ocupando 8,7 milhões de hectares $(20,8 \%)$ que se somados chegaram a um subtotal de 282 mil imóveis, ou seja, 93,3\%, ocupando uma área de apenas 17 milhões de hectares, ou 40,6\%. Há também, entre eles 13,4 mil médias propriedades $(4,4 \%)$ ocupando 7,2 milhões de hectares $(17,3 \%)$. Este conjunto que em tese estaria contemplado pela MP 458 ocupa apenas 24,4 milhões de hectares (57,4\%), a área total que o MDA/INCRA quer regularizar.

Entretanto, há também no Cadastro do INCRA 6,8 mil grandes propriedades ocupando 17,7 milhões de hectares $(42,1 \%)$. Logo, é evidente que a regularização fundiária proposta na MP 458 não se limitará apenas aos imóveis com até 15 módulos fiscais não excedendo 1.500 hectares. Por isso, havia sido incluída na MP 458 o inciso II do $\S 1^{\circ}$ do artigo 13, que garantia a estes grileiros o direito de preferência no processo licitatório. E mais, comprova-se a intenção do MDA/INCRA de licitar áreas até 1.500 hectares destas terras públicas da reforma agrária que somam mais de 40 milhões de hectares.

Cabe ainda destacar a questão relativa à instituição INCRA criada para promover a reforma agrária e a regularização fundiária no país. Em primeiro lugar, é preciso reafirmar que foi a reforma agrária que saiu perdendo, pois a MP 458 retirou do órgão as competências para coordenar, normatizar e supervisionar o processo de regularização fundiária de áreas rurais na Amazônia Legal, expedir os títulos de domínio ou de concessão de direito real de uso correspondentes e efetivar a doação sobre as terras públicas do próprio INCRA. Esta transferência de competência tem prazo de cinco anos podendo ser renovado por igual período, cabendo a partir de então ao Ministério do Desenvolvimento Agrário, está competência. Porém, quem executará 
as medidas administrativas e as atividades de natureza operacional, será o próprio INCRA por meio de seus servidores.

Assim, o INCRA perdeu a competência e o poder de decisão sobre a regularização fundiária como política conjunta da reforma agrária, e o Ministério do Desenvolvimento Agrário criou uma secretaria especial que se transformou em uma super imobiliária pública da regularização da grilagem de terras públicas do INCRA na Amazônia Legal. E mais, o nome do programa governamental para implementar a MP 458, não poderia ser melhor: Programa Terra Legal.

Dessa forma, o presidente Luiz Inácio entrou para a história da grilagem de terra do Brasil como o terceiro mandatário a realizar tal ato, passando a figurar junto com o Imperador D. Pedro II e com o ditador Getúlio Vargas na galeria do apoio aos grileiros de terras públicas.

ATO 10 - As máscaras caem: A Stora Enso obtém o aval para a regularização de terras no Rio Grande do Sul

Aprovada a conversão da MP 458 em Lei no 11.952 de 25/06/2009, as máscaras do INCRA e MDA podia juntas e em coro caírem. E foi o que aconteceu, pois, na "calada da noite" o pedido da multinacional sueco-finlandesa Stora Enso obteve o aval para a regularização das terras adquiridas na faixa de fronteira no Rio Grande do Sul. As palavras do vice-presidente da empresa na América Latina, Otávio Pontes são dignas de registro: "a decisão mostra que não cometemos ilegalidade". (VALOR ECONÔMICO, 04/09/2009)

O jornal Valor Econômico em 04/09/2009, trouxe a notícia discretamente:

"a Stora Enso conseguiu finalmente aval para regularizar o registro de terras compradas na faixa de fronteira no Rio Grande do Sul, o que impedia a maior fabricante européia de papel de levar adiante seu plano de investimento em ativos florestais. A autorização prévia foi dada pelo Conselho de Defesa Nacional (CDN), órgão de consulta da Presidência da República para assuntos ligados à soberania e defesa do Estado, no mês passado. Com a decisão assinada pelo ministro-chefe do gabinete de Segurança Institucional da Presidência da República, general Jorge Armando Félix, a Stora Enso Florestal/RS está livre para reunir a documentação e regularizar a propriedade das fazendas adquiridas entre 2004 e 2005. A Stora Enso comprou 45,7 mil hectares de terras no Rio Grande do Sul dentro do plano de chegar a 100 mil hectares no Estado com a finalidade de plantio de eucaliptos para um futuro projeto de produção de celulose. Mas ao fazer o registro das terras, a 
empresa se deparou com a negativa do cartório de imóveis. A partir daí, a empresa teve início a sua saga para regularização das terras. As fazendas estavam localizadas a menos de 150 quilômetros da fronteira brasileira, ferindo legislação brasileira que proíbe a posse em áreas rurais por parte de empresas com capital estrangeiro, exceto se autorizadas pelo governo federal. ‥ Para evitar que houvesse problemas de posse numa eventual invasão de terras, a Stora Enso colocou as propriedades nas mãos da Azenglever Agropecuária, uma empresa cujos sócios, brasileiros natos, eram executivos da própria empresa. À época, ambientalistas acusaram a empresa de driblar a lei. O Ministério Público gaúcho investigou o caso, mas a Justiça arquivou a ação. Chegou-se a discutir até a mudança da lei, reduzindose a distância até a fronteira. "A empresa fez o registro temporário na Azenglever até a autorização do $C D N^{\prime \prime}$, disse o vice-presidente da Stora Enso na América Latina, Otávio Pontes. "A decisão mostra que não cometemos nenhuma ilegalidade no processo." Embora os obstáculos para regularização das terras no Rio Grande do Sul estejam eliminados, a fabricante sueco-finlandesa disse que não sabe ainda quando serão retomadas as compras de terras. " $A$ crise afetou muito o setor de celulose", disse Pontes. Além do Rio Grande do Sul, a Stora Enso é sócia da Fibria (união da VCP com Aracruz) na Veracel, uma fabricante de celulose na Bahia, que possui um plano de duplicação, hoje congelado. Em maio, a Stora Enso e a chilena Arauco adquiriram o projeto de reflorestamento da espanhola Ence no Uruguai. Com à aquisição, as empresas formaram uma joint venture reunindo todos os seus ativos florestais no país vizinho. Ao todo, as empresas possuem 123 mil hectares de terras com plantios, madeira suficiente para uma fábrica de celulose. Pontes ressalta, contudo, que não há decisão também sobre uma unidade industrial no Uruguai."22

Assim, repetiu-se o que havia acontecido no escândalo durante o governo militar, em nome do interesse nacional, os crimes cometidos contra a legislação brasileira vão sendo perdoados. Mas, ainda faltavam outros atos para completar a peça teatral do fabricado "escândalo" da aquisição de terras por estrangeiros no governo do ex-sindicalista e operário Luís Inácio: "a lei do jeitinho brasileiro".

\section{ATO 11 - "Eu vejo o futuro repetir o passado, eu vejo um museu de grandes novidades"23: a multinacional Stora Enso ensina ao capital estrangeiro a famosa "lei do jeitinho brasileiro"}

No Brasil parece que a história insiste em ser sempre a reprodução do passado. Foi o que aconteceu nesse "escândalo" fabricado da aquisição de terras por estrangeiros no Brasil. Em primeiro lugar, as terras foram legalizadas, ou seja, a legislação brasileira, embora restritiva, acaba sempre historicamente, autorizando sua aquisição por

\footnotetext{
${ }^{22}$ http://www.valoronline.com.br/impresso/empresas/102/96602/stora-enso-obtem-aval-pararegularizacao-de-terras-no-rs - Acessado em 03/07/2011 às 21:30hs.

${ }^{23}$ CAZUZA e ARNALDO BRANDÃO "O tempo não para".
} 
estrangeiros. Aliás, desde muito tempo o Brasil assiste quase calado o processo de internacionalização de sua economia. Porém, há um ponto que permite a conexão e entendimento desse processo: uma parcela expressiva da burguesia brasileira tem se locupletado com o apoio incondicional à internacionalização da economia brasileira.

Aliás, mais do que isso, ela é capaz de ensinar ao capital mundial o "jeitinho brasileiro de tornar a ilegalidade igual a legalidade". Veja-se o que o executivo brasileiro Otávio Pontes, vice-presidente da Stora Enso para a América Latina, em entrevista ao jornal Correio Braziliense de 14/06/2010, ensinou:

"O vice-presidente da Stora Enso para a América Latina, Otávio Pontes, relatou ao Correio o processo de aquisição de terras na faixa de fronteira do Rio Grande do Sul, com a utilização de uma empresa "brasileira" criada por ele e por outro executivo da multinacional. A estratégia foi usada para que as propriedades fossem registradas provisoriamente em cartório sem a prévia autorização do Conselho de Defesa Nacional (CDN). Agora, o conselho deu permissão para a Stora Enso comprar a empresa "brasileira". No Rio Grande do Sul, a Stora Enso comprou terra em vários municípios da fronteira.

Por que essas aquisições não estão registradas no cadastro do INCRA? Lá são terras que foram compradas em zona de fronteira. E, para isso, precisa de uma autorização do Conselho de Defesa Nacional. Essa autorização já foi dada. Agora, o processo de registro de terras ainda não aconteceu porque essas coisas são lentas. O processo ainda não acabou.

Quantos hectares serão adquiridos ao todo?

Serão 46 mil hectares.

A Azenglever foi criada para comprar terras sem a autorização do $\mathrm{CDN}$, não é isso?

Ela foi criada pelo seguinte: como o INCRA demorou muito para encaminhar esse processo para o CDN, ficaram terras sem registro em cartório. Então, ficaram terras sem dono, o que não é conveniente. Você fica sem autoridade. Então, foi feita a Azenglever para que você pudesse registrar a terra até que o processo fosse aprovado pelo $C D N$.

A Azenglever era uma subsidiária da empresa (Stora Enso)?

Não. Pelas leis brasileiras, para você poder registrar terras em zona de fronteira sem a autorização prévia do CDN, você precisa ter sócio brasileiro com capital brasileiro. Então, essa foi a forma de poder registrar. Esse processo foi transparente, nunca se escondeu isso. Ministério Público, INCRA, ninguém pode dizer que não sabia desse processo. Agora a decisão aconteceu e estamos partindo para o registro das terras em nome da Stora Enso.

Com que capital a Azenglever comprou essas terras? Ela tinha esse capital?

Ela não tinha capital... mas isso também foi aberto. A Stora Enso fez um empréstimo para essa empresa. Ela comprou e deu as terras em garantia. Um procurador pediu para investigar, mas não houve nenhum problema. O processo foi absolutamente legal.

Essa autorização prévia dada pelo conselho não deveria ter acontecido antes das compras? 
Não pode. Você tem que comprar para depois... Você não tem autorização prévia para as compras. Se houvesse uma ação do INCRA rápida, ok, você compra e, dois ou três meses depois, pede autorização, faz o registro e acabou-se. Agora, quando o processo leva dois ou três anos...

A autorização prévia acabou acontecendo anos depois de compra?

Ah! Foi. ( CORREIO BRAZILIENSE, 14/06/2010) ${ }^{24}$

\section{ATO 12 - No contra-ponto do espetáculo a tentativa do enquadramento: a CPMI do MST}

Em 28 de setembro de 2009, um pouco mais de um mês depois da conversão em lei da MP 458, o MST de São Paulo ocupou a fazenda Santo Henrique grilada pela Cutrale no município de Borebi no interior paulista. Sobre a grilagem e a compra ilegal da fazenda pela empresa mundial, nenhum comentário na mídia, apenas a crítica virulenta contra o movimento. Documento divulgado pelo MST de São Paulo mostrava à sociedade brasileira mais um ato de grilagem de terras públicas:

\section{"Cutrale usa terras griladas em São Paulo \\ 6 de outubro de 2009}

Cerca de 250 famílias do Movimento dos Trabalhadores Rurais Sem Terra (MST) permanecem acampadas desde a semana passada (28/09), na fazenda Capim, que abrange os municipios de Iaras, Lençóis Paulista e Borebi, região central do Estado de São Paulo. A área possui mais de 2,7 mil hectares, utilizadas ilegalmente pela Sucocitrico Cutrale para a monocultura de laranja - o que demonstra o aumento da concentração de terras no país, como apontou recentemente o censo agropecuário do IBGE.

A área da fazenda Capim faz parte do chamado Núcleo Monções, um complexo de 30 mil hectares divididos em várias fazendas e de posse legal da União. É nessa região que está localizada a fazenda da Cutrale, e onde estão localizadas cerca de 10 mil hectares de terras públicas reconhecidas oficialmente como devolutas, além de 15 mil hectares de terras improdutivas.

A ocupação tem como objetivo denunciar que a empresa está sediada em terras do governo federal, ou seja, são terras da União utilizadas de forma irregular pela produtora de sucos. Além disso, o Instituto Nacional de Colonização e Reforma Agrária (Incra) já teria se manifestado em relação ao conhecimento de que as terras são realmente da União, de acordo com representantes dos Sem Terra em Iaras.

Como forma de legitimar a grilagem, a Cutrale realizou irregularmente o plantio de laranja em terras da União. A produtividade da área não pode esconder que a Cutrale grilou terras públicas, que estão sendo utilizadas de forma ilegal, sendo que, neste

\footnotetext{
${ }^{24}$ http://www.mst.org.br/node/10094 - Acessado em 04/07/2011, às 00:18hs.
} 
caso, a laranja é o símbolo da irregularidade. A derrubada dos pés de laranja pretende questionar a grilagem de terras públicas, uma prática comum feita por grandes empresas monocultoras em terras brasileiras como a Aracruz (ES), Stora Enzo (RS), entre outras.

O local já foi ocupado diversas vezes, no intuito de denunciar a ação ilegal de grilagem da Cutrale. Além da utilização indevida das terras, a empresa está sendo investigada pelo Ministério Público do Estado de São Paulo pela formação de cartel no ramo da produção de sucos, prejudicando assim os pequenos produtores. A empresa também já foi autuada inúmeras vezes por causar impactos ao ecossistema, poluindo o meio ambiente ao despejar esgoto sem tratamento em diversos rios. No entanto, nenhuma atitude foi tomada em relação a esta questão.

Há um pedido de reintegração de posse, no entanto as famílias deverão permanecer na fazenda até que seja marcada uma reunião com o superintendente do Incra, assim exigindo que as terras griladas sejam destinadas para a Reforma Agrária. Com isso, cerca de 400 famílias acampadas seriam assentadas na região. Há hoje, em todo o estado de São Paulo, 1,6 mil famílias acampadas lutando pela terra. No Brasil, são 90 mil famílias vivendo embaixo de lonas pretas. Direção Estadual do MST-SP"25

A justiça de Lençóis Paulista ignorando a grilagem, concedeu ação de despejo e os sem terras deixaram a fazenda. Entretanto, de forma sórdida foram acusados de destruição e roubo, embora as fotos divulgadas mostrassem uma certa arrumação nas peças dos maquinários no pátio da oficina, que comparada a qualquer outra foto de atos de vandalismo jamais traria essa ordem. Tanto foi verdade o uso político das cenas montadas, que no início de 2011, decisão unânime da $3^{\mathrm{a}}$ Câmara Criminal do Tribunal de Justiça do Estado de São Paulo (TJ-SP), determinou o trancamento do processo instaurado contra integrantes do MST, acusados da prática de crimes durante a ocupação da Fazenda Santo Henrique/Sucocitrico Cutrale entre setembro e outubro de 2009.

Assim, junta-se dois fatos políticos: primeiro, o caso do aval do governo petista para que também, a empresa mundial Stora Enzo, pudesse regularizar as terras adquiridas de forma irregular via "empresa brasileira laranja" no Rio Grande do Sul; e, segundo, ato da ocupação da fazenda grilada da empresa mundial Cutrale. Para encobrir o primeiro, o segundo foi usado pela banca ruralista no Congresso Nacional, como estopim para criação da CPMI do MST. Era preciso calar momentaneamente aqueles que manifestavam-se contra a grilagem de terras no país.

Dessa forma, na manhã do dia 21 de outubro de 2009, quarta-feira, foi lido o requerimento, curiosamente ou coincidentemente, apresentado pelo deputado Onyx

\footnotetext{
${ }^{25}$ http://www.mst.org.br/node/8283 - Acessado em 04/07/2011, às 1:00h.
} 
Lorenzoni (DEM-RS) para criação da Comissão Parlamentar de Inquérito Mista do MST. A proposta do DEM tinha como objetivo apurar supostas irregularidades em repasses feitos pela União ao Movimento dos Trabalhadores Rurais Sem Terra: "apurar as causas, condições e responsabilidades relacionadas a desvios e irregularidades verificados em convênios e contratos firmados entre a União e organizações ou entidades de reforma e desenvolvimento agrários, investigar o financiamento clandestino, evasão de recursos para invasão de terras, analisar e diagnosticar a estrutura fundiária agrária brasileira e, em especial, a promoção e execução da reforma agrária."

$\mathrm{Na}$ realidade, a ação era contra várias entidades e organizações criadas pelo movimento para prestar assistência técnica, cooperativismo, etc. em assentamentos de reforma agrária do MST, ou seja, criminalizar os que lutam pela reforma agrária e, na realidade, criminalizar a própria reforma agrária, que já não estava mais sendo feita pelo próprio governo petista.

Em treze reuniões oficiais, foram ouvidas dezenas de pessoas, entre elas integrantes de entidades e associações que realizam atividades no campo, integrantes de vários órgãos dos ministérios do governo federal, e estudiosos questão agrária. $\mathrm{O}$ relatório final foi apresentados em julho de 2010, pelo deputado federal Jilmar Tatto (PT-SP), onde estava escrito a "inexistência de qualquer irregularidade no fato de as entidades manterem relações e atenderem público vinculado a movimentos sociais". Por pressão da bancada ruralista a CPMI foi prorrogada por mais seis meses, encerrando-se no final de janeiro de 2011, sem que mais nada fosse discutido ou votado. Como rescaldo ficou mais uma vez comprovado o papel político da grande imprensa brasileira em divulgar extensivamente a criação da CPI, para no final sequer noticiar seu encerramento sem ter sido comprovado qualquer evidência de crime nas ações das entidades e organizações dos Sem Terra. Entretanto, mais uma vez a criminalização política do MST, deixava o judiciário para ser feita de forma ostensiva pela grande mídia das elites brasileiras.

$\mathrm{Na}$ realidade, o objetivo mesmo foi tentar calar aqueles que lutam contra a grilagem das terras públicas no país. Ledo engano, pois, em 22 de agosto de 2011, a fazenda Santo Henrique da Cutrale foi novamente ocupada, no seio das lutas nacionais pela retomada das terras públicas griladas. E, como era óbvio de se esperar, novamente o judiciário concedeu ordem despejo à empresa mundial que grilou as terras da União, e as famílias do MST deixaram novamente a área, sinalizando que a luta continuaria. 
ATO 13 - O final da farsa: o Brasil a disposição do capital mundial, ou, a mudança na legislação sobre aquisição de terras por estrangeiros

Como resposta governamental e pretensamente "patriota" o governo do Partido dos Trabalhadores do presidente Luiz Inácio, cuidou de mostrar seu "patriotismo" no interior da legislação que implantou através das MPs 422 e 458. Assim, mais uma vez o nacionalismo foi evocado para se fazer uma legislação que certamente, não será cumprida, como não foram as anteriores.

Trata-se do Decreto $n^{0} 6.992$ de 28/10/2009. Ele regulamentou a Lei no 11.952, de 25 de junho de 2009, para dispor sobre a regularização fundiária das áreas rurais situadas em terras da União, no âmbito da Amazônia Legal, definida pela Lei Complementar no 124, de 3 de janeiro de 2007, ou seja, a famosa Medida Provisória $\mathrm{n}^{\mathrm{o}}$ 458 de 10/02/2009.

O Decreto 6.992/09 proíbe estrangeiros e empresas estrangeiras de adquirirem terras na Amazônia que tenham sido regularizadas pelo Programa Terra Legal. O programa prevê a regularização de propriedades de 268 mil posseiros que ocuparam áreas na região até dezembro de 2004. De acordo com o decreto, os beneficiários do Programa Terra Legal podem vender áreas entre 400 e 1,5 mil hectares apenas três anos após a titulação pelo programa, desde que o comprador seja brasileiro nato ou naturalizado e não seja uma empresa. Estipula ainda, que áreas onde já ocorreram conflitos agrários ou desmatamento recente sejam vistoriadas pelo Ministério do Desenvolvimento Agrário e pelo Instituto Nacional de Colonização e Reforma Agrária (INCRA) antes de serem regularizadas. Quem viver verá, se de fato, ele será cumprido!

A outra mudança de cunho legal do governo de Luiz Inácio sobre à aquisição de terras por estrangeiros foi a revisão do Parecer GQ-181/1998 AGU. Através do novo instrumento legal aprovado Parecer CGU/AGU No 01/2008-RVJ, publicado no Diário Oficial da União de 23/08/2010.

Neste parecer o governo regulamentou à aquisição de terras por empresas controladas por capital estrangeiro e limitou à aquisição de terras no país, a estrangeiros ou empresas brasileiras controladas por estrangeiros a no máximo cinco mil hectares. $\mathrm{O}$ parecer lembra também que a soma das áreas rurais controladas por estrangeiros, não poderá ultrapassar $25 \%$ da superfície do município.

Na mídia o grupo O Globo noticiou que 
"o advogado-geral da União, Luís Inácio Lucena Adams, afirmou ... que a medida é necessária para preservar o 'controle nacional' sobre a propriedade de terras. 'Não vai excluir a participação estrangeira, mas preservar o controle nacional', afirmou. Adams disse achar 'possivel que empresas possam recorrer à Justiça', mas não espera uma avalanche de ações. O parecer fixa nova interpretação para a Lei $\mathrm{n}^{\circ}$ 5.709/71. A AGU tomou como base o princípio da soberania aplicado à ordem econômica e o artigo 171 da Constituição Federal ... Segundo o consultor-geral da União, Ronaldo Vieira Junior, o parecer 'vai tornar possível o conhecimento, controle e fiscalização sobre a movimentação de compra de terras por estrangeiros, possibilitando que sejam estendidas às empresas brasileiras controladas por estrangeiros, as limitações quanto ao tamanho das terras compradas'. ${ }^{26}$ (grifo meu)

O parecer também, obviamente,

\begin{abstract}
"levou em consideração alterações no contexto social e econômico no Brasil, bem como aspectos como a valorização das commodities agrícolas, a crise mundial de alimentos e o desenvolvimento de biocombustíveis. Com a nova interpretação, as compras de terras serão registradas em livros especiais nos cartórios de imóveis. Todos os registros de aquisições feitas por empresas brasileiras controladas por estrangeiros devem ser comunicados trimestralmente à Corregedoria de Justiça dos estados e ao Ministério do Desenvolvimento Agrário. Para Adams, 'as aquisições já efetuadas serão preservadas, as novas aquisições terão que seguir o que determina o parecer e as empresas que já têm terras além do limite legal não poderão fazer novas aquisições'. Segundo ele, o limite não inibirá investimentos estrangeiros. 'Os estrangeiros vão ter que estabelecer parâmetros de relacionamento com empresas nacionais de forma mais colaborativa, obviamente sem ter o controle ${ }^{\prime \prime} \cdot{ }^{27}$ (grifo meu)
\end{abstract}

Porém, ninguém citou uma palavra sequer, sobre o artigo 12 da Lei n ${ }^{\circ}$ 5.709/71, que permite os estrangeiros adquirir até um quarto da área do país, ou seja, comprarem até 212,869 milhões de hectares do território brasileiro, desde que não ultrapassem 1/4 das áreas dos municípios. Aliás, nem mesmo o PL nº 2.289/07 de autoria do deputado Beto Faro (PT-PA), que já foi superintendente do INCRA em Belém no Pará, e, que foi envolvido na Operação Faroeste da Policial Federal, por envolvimento em processos de grilagem de terra, toca neste ponto fundamental. Este PL, já aprovado pela Câmara dos Deputados, está sendo analisado por uma subcomissão da Comissão de Agricultura, Pecuária, Abastecimento e Desenvolvimento Rural no Senado Federal. O projeto de lei proíbe pessoas físicas e jurídicas estrangeiras de comprar ou arrendar terras com mais

26 http://g1.globo.com/politica/noticia/2010/08/governo-limita-compra-de-terras-por-estrangeiros.html Acessado em 04/05/2011, às 17:23hs.

${ }^{27}$ Ibidem. 
de 35 módulos fiscais, em área contínua ou descontínua, ou com área superior a 2,5 mil hectares.

\section{Último ATO - A apoteose: o tema da estrangeirização de terras chega ao mundo acadêmico.}

A difusão das informações sobre aquisição de terras por estrangeiros a partir do site da GRAIN, do INCRA, e, dos relatórios de ALVIM (2009) e PRETTO (2009), além da divulgação midiática sobre o assunto, abriu a frente de produção acadêmica nas universidades brasileiras sobre a temática. Os exemplos são os textos de Sérgio SAUER (2010), Sérgio SAUER e Sérgio Pereira LEITE (2011) e Bernardo Mançano FERNANDES (2011), entre outros. Esses trabalhos iniciaram um processo de validação científica referente a atualidade da questão sobre à aquisição de terras por estrangeiros no mundo e, consequentemente, no Brasil. Assim, sem necessariamente terem sido produzidos para tal finalidade (caberá a eles disserem se sim ou se não), passaram a dar respaldo acadêmico à farsa "fabricada" pelo ex-presidente do INCRA, e, tornaram importante, um fenômeno pretensamente novo, sobre o qual não há estudos significativos consistentes.

Assim, como destacar a presença do capital estrangeiro na compra de terras no Brasil, com a economia capitalista no país integralmente mundializada. Aliás, isso só é possível sob o fantasma da a-histórica contradição entre a burguesia nacional e a estrangeira, que a história a aliança de classe da burguesia mundial no capitalismo monopolista mundializado sepultou.

Neste particular, o texto de Bernardo Mançano FERNANDES (2011) e sua proposta conceitual de tratar esta etapa do capitalismo sob o signo da estrangeirização das terras na nova conjuntura da questão agrária parece repousar sob uma teoria do imperialismo que não tem mais capacidade de explicar a economia mundial no Século XXI. Em primeiro lugar, não fez como é recomendável, uma discussão sobre o uso da noção/conceito em geral e na geografia. Seu uso na língua portuguesa há muito tempo, é definido como fenômeno da presença de vocábulos de outras línguas nela, ou então, na geografia especificamente, foi usada por KATUTA (2007) para discutir o processo de estrangeirização no ensino de geografia. No artigo, seus exemplos de aquisição ou arrendamento de terras são desprovidos de indicadores da ordem de grandeza que elas representam em relação ao total das terras do país, como no caso da Daewoo em 
Madagascar (FERNANDES, 2011:78) uma vez que a área arrendada representa apenas e tão somente $2,2 \%$ da área do país, isto para não evocar também a legislação interna daquele país, que não foi abordada por FERNANDES. É óbvio que uma empresa arrendar uma área dessa extensão é preocupante, porém, não o suficiente para questionar a segurança nacional deste país, mesmo porque trata-se de arrendamento. De qualquer forma, neste exemplo e naqueles relativos aos arrendamentos do mapa cuja fonte é "Grain - Via Campesina - The Economist", não há exatamente uma estrangeirização das terras como quer fazer crer FERNANDES, mas sim uma mundialização monopolista da produção agropecuária do mundo. Dessa forma, talvez, fosse até indicado afirmar-se pelo reverso, que as multinacionais não estão se tornando proprietárias das terras agricultáveis do mundo, mas sim, controladoras monopolistas da produção agrícola do mundo. Até porque, não é da lógica econômica dos monopólios capitalistas do mundo operarem suas ações pela produção direta na terra, mas sim, pelo controle da circulação da produção.

A mesma crítica pode ser indicada ao texto quanto aos exemplos das informações gerais apresentadas sem dados estatísticos para sustentá-las do Banco Mundial. Aliás sobre o relatório do BANCO MUNDIAL (2011) referente ao assunto, cabe destacar que foram apenas investigadas parte das denúncias presentes no site da GRAIN, pois os diferentes países ou se negaram a fornecer informações, ou não tinham sequer dados sistematizados sobre a questão. A própria GRAIN incumbiu-se de dar o tom crítico sobre o relatório do Banco Mundial:

\footnotetext{
"Na semana que passou, em 7 de setembro de 2010, o Banco Mundial finalmente decidiu publicar o seu tão esperado relatório sobre a neogrilagem legal em escala global de terras agrícolas. Depois de anos de trabalho, vários meses de negociações políticas e sabe-se lá quanto dinheiro gasto, o estudo foi divulgado de forma casual no website do Banco - somente em inglês. 'O quadro geral a partir dos estudos de caso é de um fracasso de articulação, implementação e cumprimento de regulamentação ambiental.' $\mathrm{O}$ relatório é tanto uma decepção quanto um fracasso. Todo mundo estava esperando que o Banco trouxesse dados novos e consistentes sobre essas "aquisições de terras em larga escala", para usar sua terminologia, que criaram tanta controvérsia a partir de 2008. Afinal, o Banco teria acesso a governos e corporações de uma forma que jornalistas e pesquisadores de organizações não governamentais (ONGs) nunca conseguiriam. O próprio Banco diz que essa era a sua ambição central. Mas não há praticamente nada de novo em todo o documento de mais de 160 páginas. O Banco disse que iria examinar concretamente 30 países, mas só considerou 14. No final, as companhias se recusaram a prestar informações a respeito de seus investimentos em terras agrícolas, da
} 
mesma forma que fizeram os governos que proporcionam as terras. Devido a isso, o Banco buscou informações no farmlandgrab.org, um website operado pela GRAIN, criou um banco de dados de todos os acordos mencionados neste website, que são baseados em informações da mídia e, então, enviou equipes de consultores pra verificar se eram verdadeiros ou não." 28

O Relatório concluiu que está ocorrendo um processo de aquisição de terras em vários países após as crises alimentar e financeira de 2008. Informou, também, que 21\% dos 463 projetos identificados a partir do site farmlandgrab.org, entre outubro de 2008 e junho de 2009, cobrindo 46,6 milhões de hectares de terra (a maioria localizados na África Subsaariana) estão "em operação" e que mais da metade estão em "desenvolvimento inicial" e aproximadamente 70\% já foram "aprovados" (THE WORLD BANK, 2011:36). E por fim, o relatório afirma que a difusão desses dados são mais exageros do que realidade. Segundo a GRAIN,

"as conclusões do Banco também corroboram o que outros têm dito sobre os impactos dessas neogrilagens legais de terras. Sua conclusão geral é que os investidores estão se aproveitando da 'fraca governança' e da 'ausência de proteção legal' das comunidades locais para empurrar as populações para fora das terras delas. Além disso, ele conclui que os investimentos estão devolvendo quase zero para as comunidades afetadas em termos de empregos ou compensação, isso sem falar da segurança alimentar. A mensagem passada é que praticamente em nenhum lugar, entre os países e casos que o Banco examinou, há muito para ser celebrado: muitos investimentos (...) fracassaram em relação às suas expectativas e, ao invés de gerarem benefícios sustentáveis, contribuíram para perdas de patrimônio e deixaram as populações locais em piores condições do que estariam sem o investimento. Na realidade, apesar do esforço feito para cobrir um amplo espectro de situações, estudos de caso confirmam que em muitas ocasiões os benefícios foram menores do que o previsto ou absolutamente não se materializaram." ${ }^{29}$

Em seguida, a GRAIN informa que o relatório é mais significativo pelo que ele não diz, talvez porque ele contrariou a máxima de Raul Seixas de "ter aquela velha opinião formada sobre tudo ${ }^{\prime 30}$,ou seja:

"a maior parte do relatório é uma falácia a respeito de potencialidades para a produção agrícola, não 'a corrida global por terra', como o relatório havia sido anteriormente chamado. Ele ofusca

\footnotetext{
28 http://www.grain.org/article/entries/4247-relatorio-do-banco-mundial-sobre-a-neogrilagem-legal-deterras-uma-decepcao-e-um-fracasso - Acessado em 28/07/2011, às 17:32hs.

${ }^{29}$ Ibidem.

30 SEIXAS, R. Metamorfose ambulante, in http://letras.terra.com.br/raul-seixas/48317/ Acessado em 18/07/2011 às 19:33hs.
} 
a mente do leitor com dados e cifras sobre brechas de rendimentos e de uso da terra, e como a produtividade pode ser aumentada com pesquisa ou tecnologia inovadoras. Confundem-nos com pilhas de mapas e tabelas de zoneamentos agroecológicos que não dizem muito exceto onde, aparentemente, se localiza o maior potencial para produzir alimentos. Qualquer um que olhe para além dessa falácia pode ver que o relatório é mais significativo pelo que não diz do que pelo que diz. Se o Banco realmente quisesse esclarecer essa nova tendência de investimento ele poderia, pelo menos, ter aberto a cortina que encobre os investidores. Quem são eles? O que eles estão buscando? Quanto do fluxo de investimentos é privado e quanto é público? Sem esse tipo de informação não nos é possível analisar muita coisa." ${ }^{31}$ (grifo meu)

Quanto as terras dos estrangeiros no Brasil, está largamente mostrada neste texto sua insignificância territorial, apesar das manchetes alarmantes da mídia brasileira. Inclusive, FERNANDES adere à tese do ex-presidente do INCRA, da GRAIN e da mídia brasileira, quando repete os percentuais da distribuição territorial das terras de estrangeiros utilizando-se dos dados percentuais do total dos 4,184 milhões de hectares indicados pelo INCRA. Talvez teria sido mais prudente, como fiz anteriormente neste texto, se o pesquisador mostrasse o que representam estes valores absolutos em relação a área total desses estados e regiões brasileiras, pois assim, os $69 \%$ dos estados de MT, SP, MG, MS e BA virariam apenas 1,0\% das terras destes estados. Os $10 \%$ dos estados do PR e RS virariam apenas $1,1 \%$ e, os $12 \%$ do PA e AM, virariam apenas e tão somente $0,19 \%$. Isto para não repetir os dados já apresentados neste texto de que o total dos 4,184 milhões de hectares são também, apenas e tão somente $0,5 \%$ do território capitalista brasileiro. A mesma questão estatística está no uso dos dados do Paraguai, pois, não se discute as diferenças estruturais existentes naquele país, em decorrência da presença de brasileiros no Paraguai que inclui camponeses brasileiros (os brasiguaios) e capitalistas brasileiros.

Sempre critiquei e continuo criticar o uso dos percentuais dos dados estatísticos separados dos números absolutos, pois, geram interpretações equivocadas da realidade, ou, se prestam a justificar teses que os números absolutos derrubam.

E, o que é mais importante, o uso ideológico da questão pelo ex-presidente do INCRA para tentar retirar do centro da agenda política a questão da reforma agrária, substituindo-o por essa farsa do "novo escândalo" sobre à aquisição de terras por estrangeiros, como questão importante para a economia capitalista mundializada

\footnotetext{
31 http://www.grain.org/article/entries/4247-relatorio-do-banco-mundial-sobre-a-neogrilagem-legal-deterras-uma-decepcao-e-um-fracasso - Acessado em 28/07/2011, às 17:32hs.
} 
brasileira, tema inclusive abandonado em seus últimos trabalhos por FERNANDES e outros intelectuais que estranhamente, calaram-se frente a esta questão nos últimos anos. Aliás, FERNANDES, em pelo menos duas apresentações públicas, no SINGA em Niterói em 2009, e em Goiânia recentemente, no início de agosto de 2011, defendeu a regularização fundiária do INCRA/MDA como reforma agrária possível.

Para fechar esta análise do texto de FERNANDES, caberia informar que por certo, a melhor pista teórica para entender esse processo mundial de procura de terras por empresas mundiais, está mais na visão futura da possibilidade de controlar a produção de combustíveis renováveis, do que qualquer aventura mundial de domínio territorial. Como se pode ver, a geopolítica é muito cara aos geógrafos e à geografia com ciência.

Quanto ao artigo de SAUER (2010) apresentado em versão preliminar no XX Encontro Nacional de Geografia Agrária (ENGA) em Francisco Beltrão/PR (25 a 29/10/2010), traz como objetivo

"sistematizar informações sobre a demanda crescente por terras no
mundo e no Brasil. Como há poucos estudos e informações
sistematizadas, lanço mão de estudo do Banco Mundial (2010) e
alguns levantamento em nível de Brasil (ALVIM, 2009; PRETTO,
2009), encomendados pelo Ministério do Desenvolvimento Agrário
(MDA), além de informações da grande imprensa. A partir dos
dados disponíveis, a preocupação é explicitar razões e causas dessa
"corrida por terra" e suas conseqüências (defesa da aceleração do
crescimento resultante do aporte de capital versus a "estrangeirização"
e a perda de soberania territorial), incluindo contradições da lógica da
"improdutividade na imobilização do capital".(SAUER, 2010:72)
(grifo meu)

Dessa forma, SAUER construiu seu texto a partir do Relatório do Banco Mundial e outros estudos no plano internacional e no plano nacional, buscou apoio exatamente nos relatórios contratados pelo NEAD/MDA, fazendo eco à posição oficial defendida pelo ex-presidente do INCRA Rolf Hackbart sobre o que denomino falso "novo escândalo" sobre à aquisição de terras por estrangeiros no Brasil.

SAUER (2010) destacou também que

"segundo estudo do Banco Mundial (2010), a demanda mundial por terras tem sido enorme, especialmente a partir de 2008 , tornando a 'disputa territorial', histórica no Brasil e na América Latina, um fenômeno global. Segundo este estudo, comparativamente, a transferência de terras agricultáveis (ou terras cultivadas) era da ordem de quatro (04) milhões de hectares por ano antes de 2008. Só em 2009, mais precisamente entre outubro de 2008 e agosto de 2009, 
foram comercializadas mais de 45 milhões de hectares, sendo que 75\% destes foram na África."(SAUER, 2010:78) (grifo meu)

Porém, não informou sobre o fato de que após as visitas de campo dos técnicos do Banco Mundial nos projetos denunciados, puderam constatar que muitos deles não foram implementados, aliás, trata-se do parágrafo seguinte ao trecho destacado por SAUER do Relatório do Banco Mundial:

"em muitos casos, os negócios anunciados nunca foram implementados. Os riscos muitas vezes são grandes. Planos foram reduzidos devido a uma variedade de razões, incluindo-se objetivos irrealistas, mudança de preços, infraestrutura inadequada, tecnologia e instituições. Por exemplo, descobrimos que em termos reais na agricultura, só $21 \%$ dos negócios anunciados começaram."(THE WORLD BANK, 2011:XIV) (grifo meu)

Ainda sobre este texto de SAUER cabe destacar a pouco adequada visão apocalíptica sobre a presença estrangeira no cultivo de grãos na agricultura brasileira quando evoca o presidente da Aprosoja de Mato Grosso, que informa a existência de um milhão de hectares dessa oleaginosa em mãos estrangeiras. Talvez, tenha faltado no texto de SAUER um elemento de comparação, como por exemplo, a área plantada de soja na safra 2009/2010 que foi de 23,6 milhões de hectares. Com esse dado comparativo poder-se-ia verificar o percentual de apenas $4,2 \%$ representado pela informação do representante de classe do agronegócio, que embora esteja aliançado com o capital mundial, evoca pressupostos nacionalista ante a presença estrangeira. No mesmo diapasão está o uso por SAUER do editorial do jornal O Estado de São Paulo, baseado em entrevista do economista "pai do milagre brasileiro" da ditadura militar e da internacionalização da economia brasileira Delfim Neto, sobre notícias de que empresas chinesas poderiam comprar terras no Brasil. Dois comentários sobre este trecho do texto de SAUER. O primeiro refere-se ao uso do editorial do jornal, para defender um pseudo nacionalismo, e o segundo, o fato de que as empresas chinesas não compraram terras no Brasil, ao contrário, receberam de graça do governo petista baiano, 140 hectares em Barreiras/BA para construir unidade de armazenagem e indústria de processamento de grãos no valor de mais 4 bilhões de reais. Dessa forma, SAUER deixou de lado, o papel da mídia "comprada" pelo agronegócio, na divulgação de notícias sobre aquisições de terra que funcionam como alavanca para subida de preços da terra e consequente apropriação da renda capitalizada da terra pelos proprietários rentistas brasileiros. E mais, sobre a eficácia do novo parecer da AGU, em regular a aplicação da Lei $n^{\circ}$ 
5.709/71, SAUER não fez nenhuma menção em seu texto sobre o significado do seu artigo 12, que como já afirmei neste texto, garante o direito dos estrangeiros de adquirirem até $1 / 4$ das terras brasileiras, ou seja, podem comprar 212,869 milhões de hectares.

Entretanto, SAUER foi claro no reforço à tese do ex-presidente do INCRA/MDA, quando escreveu que o governo federal caminhava em posição distinta daquela que estava ampliando as aquisições de terras por estrangeiros: "em uma perspectiva distinta, o Executivo Federal, a partir da preocupação com uma possível perda de soberania territorial e de posições do INCRA, solicitou que a Advocacia Geral da União (AGU) fizesse uma revisão do Parecer GQ n 181."(SAUER, 2010:83) (grifo meu)

O texto de SAUER \& LEITE (2011) foi apresentado entre 06 e 08/04/2011, na The International Conference on Global Land Grabbing, organizada pela Land Deals Politics Initiative (LDPI) em colaboração com o periódico Journal of Peasant Studies e realizado no Future Agricultures Consortium do Institute of Development Studies, University of Sussex. Tem também, como primeiro fundamento o Relatório do Banco Mundial, já comentado neste texto, e dedica sua maior parte demonstrando o crescimento e expansão territorial da agricultura de commodities no país. Os autores informam os leitores que o "texto reconstrói e atualiza as contribuições anteriores dos autores sobre o tema, especialmente LEITE e WESZ JR. (2010), SAUER (2010) e SAUER e LEITE (2010) e (2011:1). Portanto, os comentários já feitos ao texto anterior de SAUER também se aplicam a este texto em co-autoria com LEITE, onde os pontos relativos à aquisição de terras por estrangeiros repetem-se, inclusive o aval aos relatórios de ALVIM (2009) e PRETTO (2009) elaborados para o NEAD/MDA, reforçando internacionalmente, de forma direta, as teses do ex-presidente do INCRA e do MDA sobre a questão. Também, neste texto a questão sobre o artigo 12 da Lei $\mathrm{n}^{\circ}$ 5.709/71 não é tratada, parecendo mesmo, que o efeito midiático da questão enfeitiçou muitos.

Por isso, diante das posições assumidas neste texto é necessário esclarecimentos sobre as noticias e as manchetes alarmantes da mídia impressa no Brasil sobre à aquisição de terras por estrangeiros, e, não se trata de ignorá-las porque elas existem, mas de entendê-las em seu contexto nacional e mundial. 


\section{O adeus à reforma agrária pelo governo do PT e da luta pela terra pelos movimentos sócio-territoriais e sindicais}

Em artigo que escrevi para o site Radioagência Notícias do Planalto, em 2008, chamei atenção para o fato de que estava havendo um silêncio profundo sobre a reforma agrária. Informava aos leitores e ouvintes que o II PNRA tinha terminado em 2006 e as metas do PPA (Plano Plurianual), também encerrara-se em 2007, e, que a partir de 2008, o governo não tinha mais a obrigação de fazer a reforma agrária. Afinal, nem o governo de Luiz Inácio no segundo mandato tinha se proposto a fazer o III PNRA, muito menos os movimentos sócioterritoriais e ou sindicais estavam reivindicando-o. Aliás, esses movimentos já davam todos os sinais que tinham abandonado a luta pela reforma agrária.

Os resultados finais do II PNRA, segundo o INCRA era um festival de mentiras, que dura até hoje. Este órgão insiste em divulgar os dados referentes às Relações de Beneficiários (RBs) emitidas como se fosse as metas de assentamentos novos previstas na meta 1 do plano. Assim, os dados divulgados enganosamente juntam assentamentos novos (a verdadeira reforma agrária) com regularização fundiária, reordenação fundiária (reconhecimento de assentamentos antigos, etc.) e reassentamentos de atingidos por barragens. Assim, entre as 448.954 famílias que tiveram sua RBs emitidas entre 2003 e 2007 havia apenas 137.657 famílias em assentamentos novos, a meta 01 do II PNRA. As demais eram 121.874 famílias de regularização fundiária, a meta 02 do II PNRA; mais 187.423 famílias de reordenação fundiária e 2.000 famílias de reassentamentos de atingidos por barragens. Assim, o II PNRA terminou com apenas $25 \%$ da meta de 550 mil famílias em assentamentos novos atingida; e mesmo, para a meta 02 relativa à regularização fundiária, estava previsto a regularização de 650 mil posses, porém, foram regularizadas apenas $18,7 \%$ desta meta. Os demais dados foram agregados aos anteriores para inflar os números da não reforma agrária do governo de Luiz Inácio no primeiro mandato.

Mas, o INCRA continua iludindo a sociedade brasileira afirmando que nos oito anos do governo de Luiz Inácio ele teria assentado 614.093 famílias (JORNAL DO INCRA, DEZ/2010:3), na realidade essas foram as famílias beneficiárias, porém, o total de assentamentos novos foi de 162.387 famílias, e 146.588 famílias em posses regularizadas. Além, de 2.342 famílias reassentadas pois foram atingidas por barragens e o total de 302.776 famílias envolvidas em reordenação fundiária, ou seja, substituição 
de famílias em assentamentos antigos e reconhecimento de assentamentos estaduais e antigos, etc. Dessa forma, o governo de Luiz Inácio concluiu seus oito anos de dois mandatos cumprindo apenas um quarto das metas previstas no II PNRA.

Mas voltando ao artigo que escrevi uma questão estava posta: porque o silêncio sobre a reforma agrária?

Se há algo que deixa qualquer estudioso intrigado é o silêncio sobre uma determinada questão. A defesa da reforma agrária que sempre foi bandeira do pensamento progressista e revolucionário, parecia que estava a meio pau. Poucos se manifestaram, entre eles José Juliano de Carvalho Filho (VALOR ECONÔMICO, 22/02/2008), João Pedro Stédile (O ESTADO DE SÃO PAULO, 24/02/2008:A17) liderança do MST e Dom Tomás Balduíno da CPT (ISTO É, 16/01/2008). Entretanto, parecia que para a maioria dos intelectuais seria melhor que a questão agrária não existisse, e que a luta pela reforma agrária tivesse sido encerrada. Mas, via de regra, todo mês o Brasil real era e é até hoje, sacudido pelos conflitos de terras.

O refluxo do movimento de massas e o fluxo dos recursos financeiros governamentais canalizados para as políticas compensatórias (bolsas de todo tipo e estilo, etc.), parecia que estavam aquietando aqueles que lutaram bravamente pela reforma agrária nos últimos 30 anos. Mas, era preciso dizer também, que havia apenas um aparente silêncio das massas camponesas. E, aparentemente, tudo indicava que os dois processos intercambiavam-se. Mas, os dados da CPT do livro sobre conflitos no Campo foram mostrando uma nova face da luta pela terra no Brasil. Em primeiro lugar, de fato o número de ocupações de terras que bateu o recorde em 2004, com mais de 76 mil famílias, foi diminuindo e, em 2007, os números indicavam apenas 37 mil famílias mobilizadas, para chegar em 2010 com apenas 16.858 famílias mobilizadas. O número de novas famílias que foram para os novos acampamentos também despencou: em 2003, um total de 59 mil novas famílias foi para os acampamentos, enquanto que em 2010, os números indicavam apenas 3.579 famílias. Ou seja, os movimentos sócioterritoriais tinham mudado sua rota política construída desde a década de 80 do século passado.

Entretanto, os próprios dados da CPT, passavam a revelar uma outra realidade. Trata-se do aumento, a partir de 2009, dos conflitos de terra, ou seja, à luta desesperada pela terra, muitas vezes solitária, dos camponeses posseiros, somava-se a presença da luta pelo território dos remanescentes de quilombos e dos povos indígenas. Os posseiros envolveram em 2010, mais de 17,7 mil famílias em luta, enquanto que os Sem Terra 
mobilizaram 14,9 mil. E, esse aumento da luta dos posseiros em 2010, deu a eles o protagonismo da luta no campo, superando aquelas dos movimentos sócioterritoriais e sindicais. Estão mostrando que a luta camponesa pela terra sempre foi maior que a luta desse período histórico dominada pelos movimentos organizados.

Além de tudo isso, o segundo mandato de Luiz Inácio serviu também para revelar que o agronegócio continuava mostrando seu lado agrobanditismo, pois, no meio do "tiroteio" do episódio das listas de fazendas pecuaristas habilitadas para fornecer gado para exportação à União Européia, foi revelado mais uma bandidagem, agora acobertada pelo Ministério da Agricultura, contra a reforma agrária. Foi o episódio dos "bois virtuais" ou de "papéis".

Os jornalistas Mauro Zanatta e Bettina Barros fizeram a revelação no jornal Valor Econômico:

\begin{abstract}
"Nos últimos seis meses, o Ministério da Agricultura descredenciou 26 de 71 certificadoras por indícios de fraude nos controles das fazendas aprovadas no Sisbov [Serviço de Rastreabilidade da Cadeia Produtiva de Bovinos e Bubalinos]. Parte das prejudicadas, contudo, obteve liminares e continua em operação. $\mathrm{O}$ descredenciamento foi embasado em flagrantes de fiscais do Ministério em 2007. Entre elas, havia adulterações nos cadastros das propriedades com a criação de "bois virtuais", segundo uma fonte do governo. Em alguns casos, a empresa registrava um rebanho virtual para ajudar o fazendeiro a driblar as vistorias do INCRA para fins de reforma agrária. Como os índices de produtividade eram baixos, "fabricava-se" bois de papel para não entrar em processo de desapropriação de terras". (VALOR ECONÔMICO, 15, 16, 17/02/2008:B14) (grifo meu)
\end{abstract}

Assim, o governo de Luiz Inácio e do Partido dos Trabalhadores revelou à sociedade brasileira sua verdadeira face em relação à reforma agrária: não fazê-la nas áreas de domínio do agronegócio e, fazê-la apenas nas áreas onde ela possa “ajudar" o agronegócio. Ou seja, a reforma agrária está definitivamente, acoplada à expansão do agronegócio, quer dizer, da agricultura capitalista mundializada no Brasil.

\title{
6. O campo sob o capitalismo monopolista mundializado e a questão da propriedade da terras por estrangeiros no Brasil.
}

O jornal Correio Braziliense, em matéria publicada em 24/08/2010, tratou a informação sobre o novo parecer da AGU de forma muito diferente do que a mídia em geral no país. Mostrou como a farsa montada pelo ex-presidente do INCRA/MDA tinha obtido, contraditoriamente, sucesso: 
"foi publicado ontem no Diário Oficial da União um despacho do presidente Luiz Inácio Lula da Silva aprovando o novo parecer da Advocacia-Geral da União (AGU), que impõe maior controle sobre à aquisição de terras por estrangeiros no país. Baseada em dados do Instituto Nacional de Colonização e Reforma Agrária (INCRA), a AGU reconheceu que o Estado brasileiro havia perdido o controle efetivo sobre à aquisição e o arrendamento desses terrenos. O parecer equipara os empreendimentos de fora à companhias brasileiras cuja maioria do capital esteja nas mãos de forasteiros não residentes no país ou de empresas estrangeiras não autorizadas a operar no Brasil. $\underline{\mathrm{A}}$ ausência de controle dessas aquisições teria gerado a valorização excessiva do preço da terra, a expansão da fronteira agrícola em áreas de proteção ambiental, o aumento da grilagem e da venda ilegal de terrenos públicos, à aquisição de propriedades em faixas de fronteira, pondo em risco a segurança nacional, além de práticas como lavagem de dinheiro e tráfico de drogas. A AGU esclarece que a nova abordagem sobre o tema surgiu a partir da crise de alimentos no mundo e da possibilidade de adoção, em larga escala, do biocombustível como importante fonte alternativa de energia. O parecer foi elaborado pelo consultor-geral da República, Ronaldo Vieira Júnior, e encaminhado ao presidente Luiz Inácio Lula da Silva pelo advogado-geral da União, Luís Inácio Adams. O parecer revisa as regras definidas pela AGU em 1998, ainda no governo Fernando Henrique Cardoso, interpretando a Constituição federal de 1988. Não havia dúvidas quanto à aplicação de restrições e limites às pessoas físicas e às empresas estrangeiras previstas na Lei $n^{\circ}$ 5.709/1971. A questão se restringia à equiparação das empresas brasileiras com controle de capital estrangeiro às companhias gringas. Segundo o parecer assinado pelo consultor-geral, 'passados 14 anos, o novo contexto econômico mundial impunha um reposicionamento do governo federal sobre o tema'. Vieira Júnior lembrou o pronunciamento do presidente do INCRA, Rolf Hackbart, em audiência pública das comissões de Agricultura, Reforma Agrária, Defesa do Consumidor e Fiscalização do Senado, em março de 2008. Para Hackbart, o sistema vigente permitia 'a ocupação desenfreada de terras em nivel nacional por estrangeiros, mascarada legalmente, com a justificativa de serem adquiridas por empresas brasileiras. Além disso, os serviços registrais (cartórios) entendem não ser necessário a comunicação da relação dessas aquisições à Corregedoria de Justiça e ao INCRA'. A AGU havia firmado posição favorável à revisão do parecer em 2008, mas surgiram pressões contrárias, dentro e fora do governo. Naquele ano, a Associação Brasileira de Celulose e Papel (Bracelpa) enviou carta à então ministra-chefe da Casa Civil, Dilma Rousseff, externando preocupação com a eventual revisão do parecer pela AGU. Tal fato poderia 'trazer insegurança jurídica aos investidores estrangeiros, especialmente aqueles que atuam no setor de celulose e papel'. A série do Correio mostrou que a fábrica de celulose Veracel, uma associação entre a multinacional sueco-finlandesa Stora Enso e a brasileira Fibria, comprou cerca de 200 mil hectares na Bahia para plantar eucaliptos. No Rio Grande do Sul, a Stora Enso comprou 46 mil hectares na faixa de fronteira com o Uruguai e a Argentina. As pressões e a crise econômica mundial de 2008 levaram o governo a adiar a decisão sobre a revisão do parecer. Neste ano, um grupo de 
trabalho formado pelo Ministério Público Federal recomendou ao governo a alteração do texto." (CORREIO BRAZILIENSE, $24 / 08 / 2010)^{32}$ (grifo meu)

Como pode ser verificado pela matéria jornalística o governo atual de Dilma Rousseff, pisa em ovos, pois foi parte integrante do governo anterior que participou do "escândalo" fabricado. De qualquer forma, a reportagem indica que a pressão política dos grupos econômicos mundiais são determinantes na condução da política interna nacional. Isto quer dizer que as leis nacionais são limites que serão transgredidos quando a acumulação do capital assim o exigir e os "executivos de plantão" das multinacionais, testas de ferro do capital mundial, sempre estarão zelando, não pelo patrimônio nacional, mas sim pelos seus ganhos e pelos de seus patrões membros do capital mundial. E, o governo do Partido dos Trabalhadores está a exigir legalmente, um lugar para a burguesia brasileira proprietária de terra rentista no processo de aquisição de terras por estrangeiros e, consequentemente, no desenvolvimento capitalista mundializado no Brasil.

E, para que não se diga que não falei de flores, para lembrar Geraldo Vandré, o texto final da matéria do Correio Braziliense é irretorquível:

"o Conselho Nacional de Justiça (CNJ) foi orientado a exigir dos cartórios que passem a informar ao INCRA a relação de propriedades de empresas brasileiras com capital estrangeiro. No mês passado, o CNJ fez a determinação aos cartórios de todo o país. Pela legislação vigente no país, a compra de terras por estrangeiros está restrita a limites bem claros. A partir de 50 módulos de exploração indefinida (MEIs), à aquisição tem que ser aprovada pelo Congresso Nacional. Considerando o módulo máximo, com 100 hectares, esse limite estaria em cinco mil hectares. Porém, há no Brasil empresas consideradas nacionais, mas com capital estrangeiro, que são proprietárias de áreas de até 200 mil hectares. A série de reportagens 'Terras estrangeiras', publicada no Correio a partir de 9 de junho, denunciou a falta de informações e o consequente descontrole do governo sobre as aquisições de propriedades pelos gringos, registrando a ocupação desordenada e dissimulada em Minas Gerais, na Bahia, no Rio Grande do Sul e em Mato Grosso. No Nordeste, as reportagens mostraram a ocupação agressiva do litoral cearense por mega projetos turísticos, com a invasão de áreas virgens e de terras reivindicadas por comunidades indígenas, com a ajuda financeira do governo do estado." (CORREIO BRAZILIENSE, 24/08/2010) (grifo meu)

Assim como já informado neste texto, a tese defendida pelo ex-presidente do INCRA Rolf Hackbart, era de que em decorrência do parecer liberalizante da AGU de

\footnotetext{
${ }^{32} \mathrm{http}: / /$ www.mst.org.br/Compra-de-terras-pelo-capital-estrangeiro-precisa-ser-impedida-pela-soberanianacional $\% 20$ - Acessado em 04/07/2011, às 00:24hs.
} 
1998, as empresas teriam usado o expediente legal a luz desse parecer citado, porém, ilegal a luz da Lei n ${ }^{0}$ 5.709/71 e da Constituição Federal de 1988. Ou seja, as terras de estrangeiros estariam registradas em nome de "empresas laranjas", como havia ensinado o vice-presidente da Stora Enso para a América Latina, o brasileiro Otávio Pontes.

É importante destacar que a suspeita do ex-presidente do INCRA tem procedência, pois, o episódio da Stora Enso demonstra que ele tem razão, porém, sua suspeita, certamente deve estar ocorrendo particularmente, em dois setores: o da silvicultura e o sucroenergético. Aliás, como indiquei anteriormente neste texto, estes dois setores atuam na lógica da territorialização do monopólio, quer dizer, atuam no sentido de produzir em terra própria senão a totalidade, pelos menos a maior parte da matéria-prima que necessitam. Diferente é o que ocorre nos demais setores do campo, como por exemplo, o setor de grãos, onde os grandes monopólios - ADM, Cargill, Bunge, LDC, etc. - não produzem os grãos que monopolizam em terras próprias, por certo elas nem as tem. Ao contrário, dos setores da silvicultura e sucroenergético, no setor de grãos ocorre o processo de monopolização do território, pois nele há uma aliança de classe entre a burguesia mundial e a burguesia agrária brasileira que pode ou não ser também, proprietária de terras. Este processo ocorre nos demais setores da agropecuária brasileira e mundial, como aqueles dos diferentes tipos de carnes, leite, citrícola, café, etc. Logo, a presença de empresas e/ou estrangeiros produzindo diretamente nestes setores no Brasil, sempre existiu, porém, nunca representou qualquer ameaça a segurança da pátria. Mesmo porque o capital mundial, inclusive com presença de empresas igualmente mundiais, controlam a economia brasileira.

Uma prova cabal desta contestação está na notícia publicada no jornal O Estado de São Paulo de 30/03/2011, sob o título

"Lobby afrouxa limite de terras a estrangeiros": "Lobby de empresas do agronegócio - sobretudo dos setores sucroalcooleiro e de plantio de florestas - está fazendo o governo rever o limite legal para compra de terras por estrangeiros, que vinha se tornando mais perigoso nos últimos meses. A proposta em debate é permitir o direito de uso da terra, mas sem a garantia da posse." $(O$ ESTADO DE SÃO PAULO, 30/03/2011:A6)

E quem afiança a afirmação do jornal? Um ex-representante dos governos Luis Inácio e Dilma: 


\begin{abstract}
"Segundo o ministro da Agricultura, Wagner Rossi, a proposta de cessão de terras privadas por período de 30 a 50 anos 'está sendo construida' em debates que envolvem a Casa Civil e a AdvocaciaGeral da União. 'Precisamos de investimentos estratégicos no agronegócio', disse. Rossi contou ter recebido representantes de empresas como Bunge, Cargill e Cosan preocupadas com os limites impostos a estrangeiros desde agosto do ano passado [2010], quando um parecer da AGU [CGU/AGU No 01/2008-RVJ, de 23/08/2010] fez valer os limites a estrangeiros fixados na década de 70 a empresas brasileiras com controle de capital ou de gestão em mãos de estrangeiros ... Wagner Rossi contou que a preocupação levada ao [então] chefe da Casa Civil, Antonio Palocci, não diz respeito a investidores que buscam especular com a compra de terras no Brasil. 'O que nos despertou preocupação são os investimentos em áreas estratégicas, empresas que trazem projetos agroindustriais, geram empregos. Não podemos pôr esses projetos na mesma vala comum dos investimentos especulativos', argumentou." (O ESTADO DE SÃO PAULO, 30/03/2011:A6) (grifo meu)
\end{abstract}

Como se pode ver, o procedimento do governo brasileiro é idêntico aquele dos governos militares quando fizeram a defesa do Projeto Jari, da Georgia Pacific, etc. depois do escândalo de aquisição de terras por estrangeiros de 1968. Há entre estes dois casos, apenas uma diferença: o dos governos militares existiu verdadeiramente, o atual é uma farsa muito bem montada pelo MDA/INCRA, pois, os próprios dados do INCRA mostram a farsa, e deixam a tese fundada apenas em uma hipótese que a realidade da agropecuária mostra o contrário. Aliás, é preciso deixar registrado depois desta última notícia de O Estado de São Paulo, que a presença da Bunge e da Cargill junto com a Cosan, ocorreu, não porque elas teriam adquirido terras para cultivar grãos, mas porque elas junto com a ADM e a LDC adquiriram e/ou associaram a empresas do setor sucroenergético.

Mas, a relação entre o capital nacional e estrangeiro há muito tempo apresenta-se entrelaçado. O processo de mundialização deflagrado nos anos 80 e 90 do século passado, soldou em um outro patamar econômico e político esta relação. Veja-se por exemplo, as fusões e associações que estão ocorrendo no agronegócio no Brasil, tornando inclusive, empresas nacionais nas maiores empresas de seus respectivos setores.

Em primeiro lugar, é preciso lembrar o que está ocorrendo no setor sucroenergético, que até a década de 90 era predominantemente ocupado por empresas de origens familiares nacionais. Com a constituição da Cosan (uma aliança entre a família Dedini e parte da família Ometto) a empresa lançou ações nas bolsas de valores nacional e internacional, comprou a Esso Mobil no Brasil e depois constituiu joint 
venture com a Shell, dando origem à Raizen. Ninguém comprou ninguém, apenas aliados associaram-se no mesmo negócio.

Outro exemplo neste mesmo setor ocorreu com o grupo Santelisa Vale (aliança entre a família Junqueira e Biagi) que fundiu-se com a Louis Dreyfuss Commoditties dando origem à LDC-SEV. A composição acionária da nova empresa ficou da seguinte forma: LDC com $60 \%$, acionistas da Santelisa Vale 18\%, bancos credores $13 \%$ e novos investidores com $9 \%$.

Há também neste setor o caso do Grupo Moema (aliança entre as famílias Biagi e Junqueira) que fundiu-se com a Bunge e terão participação de cerca de $9 \%$ das ações da empresa mundial dirigida no Brasil por Pedro Parente, ex-participante do governo FHC. Ou seja, nestes dois últimos casos as famílias Junqueira e Biagi tornaram-se sócias das multinacionais Bunge e Louis Dreyfuss, o que quer dizer aliaram-se ao capital mundial, ou, o que dá na mesma, multinacionalizaram-se.

Cabe destacar também neste setor, a presença de outros grupos mundiais associados tais como o francês Tereos do Açúcar Guarani S/A, que tem participação de 31,4\% da Petrobras Biocombustível - PBio podendo elevá-la até 49\%, nas unidades São José em Colinas/SP e Andrade em Pitangueiras/SP. ${ }^{33}$ A PBio tem também, associação com o grupo São Martinho através da Nova Fronteira Bioenergia S/A, de 49\% na usina Boa Vista, em Quirinópolis/GO ${ }^{34}$. Além, da associação com Cosan, Odebrecht e Copersucar, Camargo Correa e Uniduto na Lógum, empresa de logística de etanol na qual a estatal tem participação de 20\%. (VALOR ECONÔMICO, 12, 13 e 14/08/2011:B14)

Outra empresa mundial associada a capital nacional é a Archer Daniel Midland (ADM) maior produtora de etanol de milho do mundo, aliada ao ex-ministro da agricultura Antonio Cabrera na usina Limeira do Oeste, no Triângulo Mineiro onde tem participação de $49 \%$ contra $51 \%$ do ex-ministro. ${ }^{35}$

Também, entre as empresas mundiais japonesas, a Sojitz está associada à ETH Bioenergia S/A do conglomerado Odebrecht S/A; a Itochu é parceira da Bunge em duas

\footnotetext{
${ }^{33} \mathrm{http}$ ///www.petrobras.com.br/ri/Show.aspx?id_materia=OmPRpIFUIf4Vm2H1V $4 \mathrm{Ky} 9 \mathrm{~A}==$ \&id_canal=0VoiG4kRNDYH1xC6JesJnw==\&id_canalpai=/zfwoC+leAQcwFyERVZzwQ==, Acessado em 03/08/2011, às 19:46hs, VALOR ECONÔMICO, São Paulo, 12, 13 e 14/08/2011, p. B14. Jornal da Cana, abril 2011, p. 10.

${ }^{34} \mathrm{http}: / /$ www.mzweb.com.br/saomartinho/web/conteudo_pt.asp?tipo=25152\& idioma $=0 \&$ conta $=28$.

${ }^{35}$ http://www.abramilho.org.br/noticias.php?cod=1224, Acessado em 04/08/2011, às 20:30hs.
} 
usinas de açúcar e etanol no Brasil (20\% das usinas Santa Juliana, em Minas Gerais, e da Pedro Afonso, em Tocantins) e a aliança entre a Mitsui (já aliada da Vale) e a Petrobras na Usina Itarumã em Goiás (no Complexo Bioenergético a Petrobras Biocombustíveis participa com $20 \%$ e tem como sócios a japonesa Mitsui, com 20\%, e o produtor nacional Energética do Cerrado Açúcar e Álcool Ltda, com 60\%).

Outra associação no setor foi do grupo indiano Shree Renuka Sugars, quinto maior produtor mundial de açúcar e está listado na bolsa de ações na Índia. Controla 7 usinas e 2 grandes refinarias em portos naquele país, e, desde 2010 adquiriu 4 usinas no Brasil. Entre elas estão as duas usinas adquiridas integralmente do grupo Vale do Ivaí no norte do Paraná, localizadas nos municípios de São Pedro do Ivaí e São Miguel do Cambuí, e participações em infraestrutura logística: dois terminais portuários - um de açúcar, a Pasa (Paraná Operações Portuárias), com 12,7\%, e o de álcool, Álcool do Paraná, com 9,08\%, e 8\% na CPA Trading. Nas duas outras unidades, o grupo indiano comprou 50,34\% das ações das unidade do Grupo Equipav controlado pelas famílias Toledo, Vetorazzo e Tarallo, que ficaram com os outros 49,66\%. A indiana Shree Renuka Sugars e o grupo Olam International, de Cingapura, também, constituíram uma parceria no Brasil para realizar investimentos em açúcar e etanol. A parceria não envolve as unidades já controladas pelos indianos, mas sim, as futuras aquisições que serão feitas pelos dois grupos.

O setor sucroenergético tem também, a participação do grupo de Hong Kong, Noble Group, que adquiriu da família Fernandes do grupo Cerradinho as duas usinas localizadas nos municípios de Catanduva e Potirendaba em São Paulo. Enquanto que a usina Porto das Águas, no município de Chapadão do Céu, em Goiás, continuará sob o controle da família Fernandes. Já as terras onde estão as plantações de cana que abastecem as usinas de São Paulo também continuaram como propriedade da família.

A trading suíça Glencore também associou-se à família Garieri passando a controlar 70\% da usina de etanol Rio Vermelho, de Junqueirópolis/SP. A Adecoagro S/A que tem entre seus sócios o bilionário George Soros adquiriu a Angélica Agroenergia S/A localizada em Angélica no Mato Grosso do Sul e Usina Monte Alegre no sul de Minas Gerais.

Outros setores da agricultura capitalista brasileira apresentam aparentemente processo inverso ao setor sucroenergético, ou seja, são os grupos nacionais "comprando", quer dizer fundindo-se com grupos internacionais. São os casos do Grupo Votorantin comprando as ações do grupo norueguês na Aracruz Celulose, depois da 
venda de 49,99\% das ações do Banco Votorantin para o Banco do Brasil. Como desdobramento da compra, a VCP fundiu-se com a Aracruz formando-se a Fibria. Neste mesmo setor do plantio de florestas ocorreu também a fusão entre a Duratex e a Sapitel criando a maior empresa mundial de produção de painéis de madeira.

No setor de carnes há outros exemplos: a JBS (Friboi) adquiriu a Swift argentina, a Swift Foods \& Company norte-americana, a Inalca italiana, a Smithfield Beef norte-americana, a australiana Tasman e por fim associou-se ao Grupo Bertin, tornando-se a maior empresa mundial de carne bovina. O mesmo aconteceu parcialmente com o Marfrig Group que possui atuações na Argentina, Uruguai, Chile e comprou o segmento de peru da francesa Doux Frangosul e a Seara Alimentos da Cargill no Brasil.

No setor de suco concentrado de laranja cabe destacar a já antiga aliança da Cutrale com a Coca Cola, fazendo com que ela assumisse plantas industriais da multinacional na Flórida nos Estados Unidos. Pode-se destacar também a proposta de fusão entre a Citrovita do grupo Votorantin e a Citrosuco do grupo Fischer.

É necessário destacar que muitos desses processos de fusões, associações e aquisições foram feitas com a participação do BNDES e dos fundos de pensão dos trabalhadores das estatais brasileiras. Aliás, os fundos de pensões dos empregados das estatais têm se tornado proprietários de parte das ações de muitas empresas no Brasil, revelando sua dimensão capitalista. Ou seja, esta parte do proletariado tem interesse direto na lógica capitalista de produção desses empreendimentos onde são acionistas, às vezes, até tornando-se majoritários como é o caso da Vale.

Também ganhou manchetes na mídia a intenção de empresas chinesas adquirirem terras no Brasil. Entre elas pode-se destacar "China negocia terras para soja e milho no Brasil"(O ESTADO DE SÃO PAULO, 27/04/2010:B10) e "Chineses querem mais terras no Brasil" (VALOR ECONÔMICO, 27/05/2010:A1/B14). Nestas reportagens havia apenas intenções dos chineses em aportar investimentos na agricultura brasileira, o restante era pura especulação. Já a notícia de que "Chineses já compram terras em nova fronteira agrícola" (VALOR ECONÔMICO, 27/04/2010:B12.), na realidade trazia uma meia verdade, pois na realidade, o que ocorreu foi apenas o primeiro passo para que os investimentos chineses chegassem ao Brasil: 
"o primeiro grupo de investidores chineses se prepara para desembarcar no oeste da Bahia. Depois de muitas especulações sobre o interesse de estrangeiros na região - nova fronteira agrícola -, a empresa Pallas Internacional assinou com o governo baiano, um protocolo de intenções para se instalar no Estado e produzir grãos para exportação, além de atuar em bioenergia. $\mathrm{O}$ grupo chinês, formado por investidores privados, mas com o governo da China como sócio, quer comprar de 200 mil a 250 mil hectares de terras, tanto no oeste da Bahia quanto na região conhecida como Mapito, o cerrado do Maranhão, Piauí e Tocantins. 'Eles precisavam desse protocolo para acelerar a parte burocrática na China', comemora Eduardo Salles, secretário da Agricultura da Bahia."(VALOR ECONÔMICO, 27/05/2010:A1.) (grifo meu)

Outra notícia relativa ao interesse chinês em terras brasileiras apareceu no jornal O Estado de São Paulo de 19/03/2011. Ele trouxe a seguinte informação:

"o grupo chinês Chongqing Grain Group Corporation Limited Liability Company anunciou ontem investimentos de R\$ 4 bilhões para construção de um pólo industrial de esmagamento e refino de óleo de soja e de escoamento de produtos a ser instalado em Barreiras, no oeste da Bahia ... De acordo com o secretário Eduardo Salles da Bahia, porém, o investimento em terras não foi considerado no acordo. 'Pelo contrário: eles pretendem incentivar os produtores locais, fornecendo a eles adubo e defensivos agrícolas', afirma." $(\mathrm{O}$ ESTADO DE SÃO PAULO, 19/03/2011:B14)

Como se pode verificar, é preciso muito cuidado com as informações midiáticas sobre aquisição de terras por estrangeiros, porque nem sempre aquilo que foi noticiado acontece de fato. Aliás, é preciso destacar que este investimento chinês segue a lógica das empresas mundiais do setor de grãos no país.

Entre outros exemplos da aliança de classe de setores da burguesia brasileira com a mundial, estão as novas empresas nacionais que começaram a nascer a partir de 2005, no setor sucroalcooleiro e de celulose, e, na atualidade, principalmente no setor de grãos, que estão abrindo seus capitais em bolsas de valores, ou seja, fazendo seus IPOs (Initial Public Offering - Oferta Pública Inicial de ações em Bolsas). Essas novas empresas seguem o caminho aberto pela Cosan que foi a primeira de seu setor a abrir seu capital em bolsa no ano de 2005.

Essas novas empresas de capital aberto, no campo brasileiro estão juntando de forma articulada na aliança de classe com o capital mundial, o rentismo típico do capitalismo no Brasil, e, assim, estão fazendo simultaneamente, a produção do capital via apropriação da renda capitalizada da terra e a reprodução ampliada do capital acrescida do lucro extraordinário representado pelas diferentes formas da renda da terra. 
Ou seja, passam a atuar no mercado de terras, no preparo da propriedade para produção, na produção em si e na comercialização. E mais, esses grupos interessados em terras brasileiras têm se associado a investidores e fundos, e alguns já abriram seu capital, outros estão se preparando para tal. Além do fato em si de que a negociação de terras passou a chamar a atenção do setor financeiro, a emissão de ações deu opções para os fundos, permitindo assim, que estrangeiros participem desse mercado, independentemente das ações do governo, quanto à eventuais restrições às aquisições terras por estrangeiros.

Assim, estão se formando novas grandes corporações nacionais mundializadas na área de grãos, enquanto que nos setores de açúcar e álcool e de celulose elas já são realidades. Inclusive, elas revelam em seus sites o papel que o rentismo desempenha em suas atividades e, revelam seus sócios estrangeiros aliançados.

A abertura do capital da SLC Agrícola, em 2007, é uma espécie de marco desse novo movimento, pois, foi a primeira empresa constituída por fazendas produtoras de grãos do mundo que tem suas ações negociadas em bolsas. Como parte do Grupo SLC, constitui-se em uma empresa produtora de commodities agrícolas (algodão, soja e milho). Possui onze fazendas de produção no MS, MT, GO, BA, PI e MA com 230,7 mil hectares cultivados na safra 2010/11, sendo 118,2 mil de soja, 85,0 mil de algodão, 24,8 mil de milho e 2,6 mil café, trigo e milho semente. Seu

"modelo de negócios é baseado em um sistema de produção moderno, com alta escala, padronização das unidades de produção, tecnologia de ponta, controle rigoroso dos custos ... ao longo de sua história, a SLC Agrícola desenvolveu uma sólida expertise na prospecção e aquisição de terras em novas fronteiras agrícolas. $O$ processo de aquisição de terras com alto potencial produtivo também visa capturar a valorização imobiliária que as terras agricultáveis no Brasil proporcionam em função das vantagens comparativas em relação aos principais produtores agrícolas do mundo, tais como Estados Unidos, China, Índia e Argentina." ${ }^{36}$ (grifo meu)

A SLC Agrícola prepara a constituição de sua empresa especializada na comercialização de terras, já conhecida como LandCo, que terá 90 mil hectares iniciais e capital para chegar em 2013, com 240 mil hectares, em fazendas em áreas do ecossistema do Cerrado no Centro-Oeste e Mapitoba (MA, PI, TO e BA).

"Com a criação da nova empresa, o grupo pretende agregar valor àquelas que considera serem suas maiores expertises: de um lado, a

\footnotetext{
${ }^{36}$ http://www.slcagricola.com.br - Acessado em 28/07/2011, às 9:25hs.
} 
produção agrícola em si, que permanecerá sob a responsabilidade da SLC Agrícola; do outro, a compra e a venda de terras, que ficará com a LandCo. A nova empresa terá como foco à aquisição de terras com potencial de valorização explica o diretor-presidente da SLC Agrícola Arlindo Moura. Em seguida essas terras serão arrendadas para a própria SLC Agrícola, que poderá ocupá-las com a produção de grãos. Quando as propriedades alcançarem valores satisfatórios, poderão ser vendidas pela LandCo, em um ciclo contínuo. Com base no histórico de negociação de terras da SLC Agrícola nos últimos 10 a 15 anos, explica Moura, o potencial é que os ativos ofereçam uma rentabilidade anual da ordem de $19 \%$ a $20 \%$. Os 90 mil hectares iniciais serão transferidos à LandCo pela SLC Agrícola - que assim, passará, a ter $51 \%$ da nova companhia. A fatia restante deverá ser vendida a fundos soberanos estrangeiros - entre os principais estão os de países como Qatar, Dubai, China e Cingapura. 'Já estamos negociando com alguns fundos. A idéia é que seja um pool deles', afirma Moura." (VALOR ECONÔMICO, 27/10/2010:B14)

Outra empresa com característica parecida é a Agrifirma. Trata-se de um grupo brasileiro que trabalha na aquisição e desenvolvimento de terras agrícolas, pretende se tornar a primeira empresa nacional a ser listada na bolsa de Hong Kong. Tem entre seus investidores o britânico Jacob Rothschild. Possui 60 mil hectares de terras no Estado da Bahia e pretende chegar a 100 mil hectares antes da abertura do capital. Aplica em média, US\$2.300 para aquisição de um hectare e transformá-lo em terra cultivada.

"O negócio da Agrifirma consiste em comprar terras, especialmente no Cerrado, e transformá-las em áreas produtivas. A empresa já levantou US\$ 179 milhões até agora, incluindo investimentos de dois magnatas de Hong Kong - Raymond Kwok e Adrian Fu - e o grupo de investimentos Lake House. 'Há uma escassez de terras cultiváveis na própria China', disse $\mathrm{Fu}$, que atua no segmento hoteleiro. 'Eventualmente, a China terá de ir ao exterior para originar seus produtos agrícolas', disse. A família Kwok controla a Sun Hung Kai Properties, maior grupo de Hong Kong a atuar no segmento de desenvolvimento de propriedades." (VALOR ECONÔMICO, 19/07/2010:B12) (grifo meu)

Outra empresa que abriu seu capital na bolsa de Nova York, no início do ano de 2011, foi a Adecoagro. A empresa tem entre seus sócios o bilionário George Soros.

"A Adecoagro S/A é hoje uma das principais empresas produtoras de alimentos e energia renovável da América do Sul. Com presença na Argentina, no Brasil e no Uruguai, as atividades a que nos dedicamos incluem a produção de grãos, arroz, oleaginosas, lácteos, açúcar, etanol, café e algodão. Em setembro do ano de 2002, a Adecoagro entra no mercado agropecuário argentino com à aquisição da firma 'Pecom Agropecuária SA' e seus mais de 74.000 hectares de terra. Naquele momento, Pecom Agropecuária era a terceira empresa agropecuária da Argentina, e esta compra de ações resultou a maior da América Latina em 2002 ... No ano de 2004 começamos nossa 
expansão regional, adquirindo uma fazenda, a Macarena, em uma das áreas mais produtivas do Uruguai ... Ao mesmo tempo, começamos a análise de possibilidades de investimento no Brasil, desembarcando definitivamente nesse país em 2005 com a compra de três fazendas localizadas nos Cerrados brasileiros. Em fevereiro de 2006, foi dado o primeiro passo no negócio agroenergético com a compra da Usina Monte Alegre em Minas Gerais, Brasil. Nesta usina são processadas 1 milhão de toneladas de cana-de-açúcar para a produção de açúcar e etanol. Em março desse mesmo ano, iniciamos o projeto Angélica Agroenergia, em Mato Grosso do Sul, Brasil. Esta usina começou a moer em meados de 2008 e processa 4 milhões de toneladas aproximadamente. Uma usina a mais completa o projeto sucroalcooleiro no Brasil e a sua construção começará no ano 2012. Desta forma, a previsão é superar as 11 milhões de toneladas para 2015. Em agosto de 2006 foi incorporado a Alfenas Café. Alfenas comercializa café brasileiro de primeira qualidade para mercados de alto poder aquisitivo, como a Europa e o Japão. Através desta empresa canaliza-se nossa produção e a de terceiros. Em outubro de 2006 foi dado um passo importante em nosso projeto de café com a compra da Fazenda Lagoa do Oeste. Esta fazenda está localizada no Oeste da Bahia e será destinada à produção de café de qualidade. Também dentro deste projeto na Bahia, em janeiro de 2007, adquirimos $50 \%$ da Fazenda Mimoso. Aqui vamos desenvolver mais de 500 hectares de produção de café sob irrigação, de excelente qualidade ... Atualmente, a Adecoagro possui mais de 270.000 hectares na Argentina, no Brasil e no Uruguai." ${ }^{37}$ (grifo meu)

A Radar Propriedades Agrícolas é subsidiária da Cosan e foi criada em 2008.

É mais uma empresa para atuar no mercado imobiliário rural. Seu objetivo é

"investir em imóveis agrícolas no Brasil, identificando propriedades com alto potencial de valorização, processando as aquisições e arrendando-as a grandes operadores agrícolas ... [controla] um total aproximado de $70 \mathrm{mil}$ hectares de terras, cultivadas principalmente com lavouras de cana e de grãos. ${ }^{38}$ (grifo meu) A empresa tem como sócios o grupo Cosan e fundos de pensão norte americanos. "A meta da empresa é expandir seus negócios ... em regiões com forte tradição no plantio de grãos. 'A Radar não pretende ser uma operadora agrícola. As aquisições destas propriedades são para fazer arrendamento para grandes produtores', afirmou ao Valor Marcelo Martins, vice-presidente financeiro e relações com o mercado da Cosan." (VALOR ECONÔMICO, 26/08/2009:B12) (grifo meu)

Outra empresa que atua no mesmo segmento é a Calys Agro.

"De olho na forte valorização que as terras brasileiras podem ter no curto e médio prazo, a americana AIG Capital Investments adquiriu $37 \%$ de participação na Calyx Agro. A empresa tem como seus principais acionistas o grupo francês Louis Dreyfus Commodities, que

\footnotetext{
${ }^{37} \mathrm{http}: / / \mathrm{www}$.adecoagro.com/.

${ }^{38} \mathrm{http}$ ://www.cosan.com.br/cosan2009/web/conteudo_pti.asp?idioma=0\&conta $=$ $45 \&$ tipo $=35726$ - Acessado em 25/07/2011, às 18:03hs.
} 
no país é gigante em grãos e está crescendo em cana. O grupo Calyx Agro também negocia propriedades rurais na Argentina e Uruguai. ' $\underline{A}$ idéia é comprar terras para investir na produção agrícola e vender essas propriedades depois', afirma Marcelo Aguiar, diretor da AIG Investments. Segundo Aguiar, a Calyx deverá abrir capital no país para futuras captações de recursos, 'Aguardamos o mercado se recuperar para ir à bolsa.' O CEO da Calyx Agro, Áxel Hinsch, conta que a empresa já tem duas propriedades na região do Mapito - nova fronteira agrícola que compreende os Estados do Maranhão, Piauí e Tocantins.'Vamos alcançar 100 mil hectares até o final do ano', disse." (VALOR ECONÔMICO, 28/08/2008:B14.) (grifo meu)

A Vision Brazil Investments é também, uma empresa que atua para

"ajudar investidores estrangeiros a alocar seus recursos em setores tais como, Agricultura, Financiamento e Crédito na área agrícola, Produção de terras agrícolas, Imobiliário ${ }^{39}$... A Vision, gestora de recursos que administra cerca de $\mathrm{R} \$ 1$ bilhão, busca oportunidades em terras para clientes estrangeiros interessados em agronegócios, conta João Adamo, diretor-comercial da empresa. A empresa foi criada em 2006 por ex-banqueiros do Bank of America no país." (VALOR ECONÔMICO, 28/08/2008:B14) (grifo meu)

Outra empresa nesse novo padrão é a Tiba Agro, criada por um grupo de produtores rurais nacionais e investidores financeiros para atuar na aquisição de propriedades rurais. Já concentra 320 mil hectares de terras no Cerrado brasileiro, total que a coloca entre as primeiras em estoque de terras. A Tiba Agro derivou de um

"projeto de uma gestora de recursos, a Vision Brazil Investments, de dois ex-executivos do Bank of America: Fabio Greco e Amauri Fonseca Junior, que têm fatia de $25 \%$ da Tiba. Para juntar os recursos necessários para à aquisição das áreas, eles levantaram US\$ 300 milhões por meio de fundos de private equity, com cotistas americanos e europeus que passaram a ter $45 \%$ da companhia. Também se uniram a dois produtores rurais, os irmãos Francioni, da Bahia, e o grupo Golin, da região Centro-Oeste, que já possuíam algumas fazendas que foram trocadas por $30 \%$ da Tiba. Agora, para dar corpo à nova companhia, todos os ativos, distribuídos em diversos veículos de investimento, estão sendo reunidos debaixo do guardachuva da Tiba Agro ... O próximo passo da Tiba Agro será colocar suas 13 fazendas no Piauí, no Mato Grosso e na Bahia para produzir grãos, principalmente soja, algodão e milho. Hoje, só há plantação em 9,3 mil hectares. Para isso, cerca de US\$ 300 milhões estão sendo levantados com investidores do Oriente Médio em um fundo private equity. Os recursos também serão utilizados para à aquisição de novas áreas ... conforme a produção avançar, a Tiba estuda separar os braços de aquisição imobiliária e de produção agrícola. A partir disso, poderia ser criado com as terras um fundo imobiliário, por exemplo." (VALOR ECONÔMICO, 15/03/2010:B15) (grifo meu)

\footnotetext{
${ }^{39} \mathrm{http}: / /$ www.visionbrazil.com/pt/company.htm, Acessado em 21/07/2011, às 20:12hs.
} 
A Sollus Capital é também um exemplo de empresa que adquire terras com capital estrangeiro e brasileiro. É

"uma empresa de investimentos em terra com potencial agrícola, preferencialmente para grãos, que cobre atualmente Brasil, Argentina, Uruguai e Paraguai. Possui 35 mil hectares de propriedades agrícolas e tem planos para chegar a 80 mil hectares, sem se envolver diretamente com a produção. A sociedade foi fundada em maio de 2008 por um grupo de características singulares e complementares. $\underline{A}$ Vinci Partners é veículo de investimento de ex-sócios do Banco Pactual, o maior banco de investimentos do Brasil e um dos maiores gestores de recursos de terceiros, a Vinci é um dos principais administradores de private equity no Brasil ... Dentre estes investimentos realizados pela Vinci estão ativos como a PDG Realty, no setor imobiliário brasileiro, e a Equatorial Energia ... Adicionalmente, possui investimentos no mercado brasileiro de etanol através da CMAA ... O Touradji Capital Management é um administrador de "hedge funds" baseado em Nova York, especializado em pesquisa fundamentalista e investimento em commodities e títulos relacionados . Atualmente, a empresa administra ativos mais de US\$ 3,5 bilhões ... O Grupo Los Grobo é uma das mais importantes empresas de agronegócios na América do Sul. Ao longo dos últimos 30 anos, a Los Grobo tem desenvolvido uma plataforma exclusiva de agronegócios na Argentina, Uruguai, Paraguai e Brasil. A Los Grobo opera em toda a cadeia do agronegócio, não somente na produção de culturas, mas também no fornecimento de produtos e serviços para mais de 5.000 fazendeiros independentes ... Atualmente, a Los Grobo administra mais de 246.000 hectares de terras plantadas e origina mais de 3 milhões de toneladas de grãos no Cone Sul." ${ }^{40}$ (grifo meu)

Ainda entre essas novas empresas há também a LG Agro do banqueiro carioca Gilberto Sayão ex-sócio do Banco Pactual.

"Hoje tem cinco fazendas de gado de corte e de grãos no Centro-Oeste ... seu objetivo ali, dizem os mais próximos, é criar 'reserva de valor' ... A LG Agro não é apenas uma fazenda. Ela avança na cadeia do agronegócio, ocupando o espaço dominado pelas tradings. Seu modelo engloba quatro áreas de atuação: imobiliária (compra e venda de terras); produção de soja, milho e trigo, basicamente em fazendas arrendadas; produção de açúcar e álcool (atualmente tem uma usina em operação e duas em execução); e, por fim, serviços (consultoria, comércio, distribuição, armazenagem e financiamento a pequenos agricultores). É uma estratégia defensiva, para não depender de apenas uma dessas áreas, explicam fontes próximas à operação. Todos esses negócios já existiam separadamente, mas foram agrupados, no fim do ano passado, numa só companhia, que já nasce com uma receita de R $\$$ 1 bilhão. O objetivo é ter o capital aberto em bolsa - o pedido de registro foi encaminhado à Comissão de Valores Mobiliários (CVM) no dia 31 de maio, mas o projeto foi adiado em função do humor do mercado de capitais ... Hoje a LG Agro produz em 254 mil hectares de

\footnotetext{
${ }^{40}$ http://www.solluscapital.com.br/Portugues/home.html - Acessado em 31/07/2011, às 8:30hs.
} 
terra e comercializa 2,7 milhões de toneladas de grãos ... O negócio imobiliário e o de açúcar e álcool, por enquanto, são modestos. No primeiro, são 30 mil hectares de terras, arrendadas exclusivamente para a Los Grobo ... Na Companhia Mineira de Açúcar e Álcool (CMAA) - empresa originalmente controlada pelo Pactual Capital Partners, JF Citrus e o fundo americano ZBI Ventures -, o objetivo é moer 12 milhões de toneladas de cana por ano quando as três usinas estiverem em operação, o que está previsto para 2014." (O ESTADO DE SÃO PAULO, 01/08/2011:N4) (grifo meu)

Já a empresa BrasilAgro possui 174 mil hectares adquiridos por um fundo da Tarpon, pela argentina Cresud e por Elie Horn (fundador da Cyrela). Seu modelo de negócio é parecido com a Tiba Agro, pois, faz a conversão de terras e a produção em 50 mil hectares. Ou seja, atua na

\begin{abstract}
"aquisição, desenvolvimento, exploração e comercialização de propriedades rurais com aptidão agropecuária. Adquirimos propriedades rurais que acreditamos ter significativo potencial de geração de valor por meio da manutenção do ativo e do desenvolvimento de atividades agropecuárias rentáveis. A partir do momento da aquisição das nossas propriedades rurais, buscamos implementar culturas de maior valor agregado e transformar essas propriedades rurais com investimentos em infraestrutura e tecnologia, além de celebrarmos contratos de arrendamento com terceiros. De acordo com nossa estratégia, quando julgarmos que as propriedades rurais atingiram um valor ótimo, venderemos tais propriedades rurais para realizarmos ganhos de capital. Desde o início de nossas operações em 2006, adquirimos um total de 10 propriedades rurais, sendo que, em junho de 2008 , realizamos a venda de uma fazenda. O nosso plano de negócios contempla a valorização de nossas propriedades rurais como o nosso principal vetor de retorno financeiro. Na nossa visão, o valor de uma propriedade rural está diretamente relacionado à geração de caixa por unidade de área. Nesse sentido, buscamos maximizar o retorno sobre os nossos investimentos." ${ }^{41}$ (grifo meu)
\end{abstract}

A Cantagalo General Grains é também empresa nova nesse segmento.

Começou com uma área total de 150 mil hectares e um aporte também inicial de R\$90 milhões dos acionistas formados pela

"união entre Coteminas, o produtor rural Vilson Vian, da Agrícola Estreito, e Paulo Roberto Moreira Garcez, fundador da trading Multigrain, que foi vendida para a multinacional japonesa Mitsui ... Nos meses de junho e julho, os sócios apresentaram a companhia a investidores estrangeiros com a missão de captar US\$ 250 milhões. $\mathrm{O}$ dinheiro será usado na compra de mais terras e na operação de trading,

\footnotetext{
${ }^{41} \mathrm{http}: / /$ www.brasil-agro.com/brasilagro/web/conteudo_pt.asp? idioma $=0 \&$ conta $=$ 28\&tipo=20101 - Acessado em 01/08/22:04hs.
} 
que exige um caixa fortalecido ... O modelo da Cantagalo é parecido com o da LG Agro, pois também vai desde a compra de terras até a comercialização de grãos. Mas, segundo pessoas próximas à operação, é mais patrimonialista que a LG Agro e Los Grobo. A Cantagalo pretende produzir soja e algodão basicamente em fazendas próprias." (O ESTADO DE SÃO PAULO, 01/08/2011:N4) (grifo meu)

Também, entre essas novas empresas estão aquelas do empresário espanhol

\title{
Enrique Bañuelos.
}

\begin{abstract}
"Com a intenção de formar um gigante, o investidor realizou, desde o ano passado, uma série de operações. Primeiro, adquiriu o controle da produtora de algodão Maeda e promoveu uma associação com a BrasilEcodiesel, que diversificou suas atividades para além do biodiesel. Recentemente, Bañuelos saiu do negócio - mas não desistiu de seus planos. Agora, ele tenta aprovar uma fusão entre a BrasilEcodiesel e a Vanguarda, produtora de algodão e soja. Metade do capital da Vanguarda pertence ao espanhol, por meio de sua holding de investimentos, a Veremonte. A outra metade é do empresário e político mato-grossense Otaviano Pivetta. Por trás desse esforço, está uma lógica financeira. Bañuelos pretende atrair sócios chineses para o agronegócio. 'A China precisa de alimentos e quer investir no Brasil. Mas esses investidores só se interessam por grandes empresas, e por isso estamos criando uma', diz Bañuelos. Se a fusão com a Vanguarda der certo, a empresa resultante terá uma receita de $\mathrm{R} \$ 1,6$ bilhão e 330 mil hectares plantados. A Veremonte já coleciona planos para a possível gigante. Entre eles está a criação de um fundo de terras como forma de capitalizar a companhia. Outro projeto é expandir o negócio por meio da compra de áreas de outros produtores - mas sem o desembolso de dinheiro. A idéia é oferecer em troca as ações da BrasilEcodiesel, que é negociada na BM\&FBovespa. 'Tem muitas famílias donas de terras com problemas de liquidez. E isso nós poderemos oferecer', diz Marcelo Paracchini, presidente da Veremonte no Brasil." (O ESTADO DE SÃO PAULO, 01/08/2011:N4) (grifo meu)
\end{abstract}

Agrinvest é outro exemplo, pois trata-se de uma empresa controlada pelo fundo americano Ridgefield Capital e dedicada à produção em 78 mil hectares de soja no Maranhão e em Mato Grosso. A empresa fez no ano de 2010 uma operação pioneira no agronegócio para obter capital no exterior. A operação financeira

"sinaliza um novo caminho para a capitalização no agronegócio. Numa das primeiras transações do gênero já realizadas por uma empresa brasileira - e a primeira no setor agrícola - , a Agrinvest emitiu títulos, do tipo private placement (cujas vendas são voltadas a investidores super-qualificados, diferentemente de uma emissão pública) na Euroclear, uma espécie de câmara internacional de compensação de títulos, e captou 26 milhões de dólares. A Euroclear, equivalente à Cetip brasileira, tem sede mundial em Bruxelas e é o maior provedor de serviços para liquidação de títulos, ações e transações de fundos de investimentos do mundo. Os títulos emitidos 
pela Agrinvest são de três anos e pagarão aos tomadores $12 \%$ ao ano, com pagamentos de juros semestrais e principal ao final dos três anos. De acordo com Roberto Martins, gestor dos ativos do Ridgefield Capital no Brasil e diretor da Agrinvest, a emissão dos títulos revelouse uma estratégia viável e vantajosa para que a empresa pudesse obter capital de giro relativamente barato. 'A maioria das linhas tradicionais de crédito no Brasil são fortemente baseadas apenas em garantias reais, como propriedade de terras, o que limita as possibilidades de financiamento para a Agrinvest, cujo modelo de negócio é predominantemente o de produção sobre terras arrendadas', diz Martins. 'A opção foi buscar investidores mais sofisticados, que entendem a capacidade de geração de renda também com a própria atividade da empresa.' A idéia surgiu em meados de março, quando a corretora americana Dinosaur Securities começou a estruturar a operação, que se concretizou em meados de setembro. A Agrinvest criou uma subsidiária nas Ilhas Cayman, que emitiu os papéis na Euroclear, garantidos pela empresa brasileira. A subsidiária capta o dinheiro no mercado e remete para o Brasil como capital de giro para a Agrinvest. Parte da garantia aos investidores é dada em exportação da soja e parte por contratos de venda que a Agrinvest tem com a Bunge, uma das maiores trading companies do setor agrícola no mundo." ${ }^{42}$ (grifo meu)

Outro caso é a empresa argentina Los Grobo, além de associada a Sollus

Capital, atua no Brasil através da Ceagro. Esta empresa

"iniciou sua história em 1995 na cidade de Balsas, estado do Maranhão ... expandindo seus negócios para o Piauí e Tocantins ... Mato Grosso, Bahia e Goiás ... A Ceagro atua hoje na distribuição de insumos, produção de soja desativada em grãos e farelo desativado de soja, produção de sementes de soja, prestação de serviços de padronização e armazenamento de grãos, transporte rodoviário de cargas, comercialização de soja e milho e na produção e exportação de grãos." 43

Por fim, entre essas empresas que estão atuando no Brasil está o Grupo El Tejar argentino. Ele atua no Brasil através da empresa "O Telhar Agropecuária Ltda", através de seu country manager Javier Angió, e tem sede em Primavera do Leste/MT. $^{44}$

\footnotetext{
"A empresa tem como sócios a empresa espanhola ET Spainco S.L, e cedeu cotas à empresa CV LUXCO S.A. R.L., de Luxemburgo, todas representadas por Javier Angió, proprietário da "O Telhar Agropecuária Ltda" ... Em Mato Grosso, o grupo desenvolve suas

42 http://exame.abril.com.br/blogs/aqui-no-brasil/2010/10/06/agrinvest-faz-operacao-pioneira-noagronegocio-e-obtem-capital-no-exterior/ - Acessado em 02/08/2011, 15:02hs.

${ }^{43} \mathrm{http}: / / \mathrm{www} . c e a g r o b r a s i l . c o m /$ site/

${ }^{44} \mathrm{http}: / /$ www.eltejar.com/por/secciones/el-tejar_22.php\&sub=0 - Acessado em 03/08/2011, às 22:12hs e http://www.nossofuturoroubado.com.br/arquivos/julho_10/terras.html - Acessado em 03/08/2011, às $22: 38 \mathrm{hs}$
} 
atividades em mais de 70 propriedades rurais, localizadas nos municípios de Primavera do Leste, Nova São Joaquim, Nova Mutum, Nova Ubiratã, Diamantino, Porto dos Gaúchos, Ipiranga do Norte, Santo Antonio do Leste, Sinop, São José do Rio Claro, General Carneiro, Lucas do Rio Verde, Brasnorte e Santa Rita do Trivelato. A empresa ocupa 206 mil hectares com plantações de soja, milho e algodão ... Cerca de 40 mil hectares são áreas próprias. O restante é arrendado de brasileiros. Produz 680 mil toneladas de grãos por ano. Na América do Sul, especificamente, El Tejar atua em uma área superior a 700 mil hectares. No cartório de registro de imóveis de Primavera do Leste (MT), ... as terras estão registradas, mas não constam no livro de propriedades de estrangeiros. 'Pela nossa legislação, ela é uma empresa brasileira', explica o responsável pelo cartório, Herbert Fernandes Silva. No registro de terras estrangeiras do Instituto de Colonização e Reforma Agrária (INCRA), nada consta sobre as terras de EI Tejar ... Em seu site, informa que aplica o seu modelo de negócios para identificar, arrendar, adquirir e operar fazendas ... Em vez de operar diretamente as fazendas, prefere terceirizar integralmente o processo de produção, do plantio à colheita, utilizando quase sempre o trabalho dos fazendeiros que vendem ou arrendam as terras ... O presidente da Associação de Produtores de Soja e Milho de Mato Grosso (Aprosoja), Glauber Silveira, afirma que a atuação de O Telhar 'é predatória'. Primeiro, porque oferece preços elevados e fora da realidade pelo arrendamento, afastando produtores brasileiros do processo produtivo. Segundo, por transferir aos terceirizados os custos trabalhistas e tributários. 'Eles pagam 10 sacos de soja o arrendamento, quando o valor de mercado é sete. Mas os proprietários arrendam a terra e assumem e produção. Daqui a cinco anos, não terão mais máquinas'. A O Telhar informou ao Correio Braziliense, por meio de nota, que iniciou as atividades em 2003, com arrendamentos e parcerias. Só a partir de 2007 adquiriu terras próprias, para assegurar a expansão da atividade ... Em relação à constituição de uma empresa no Brasil, disse que 'isso faz parte dos trâmites legais exigidos para atuar no país. $\mathrm{O}$ foco da atuação de $\mathbf{O}$ Telhar não é à aquisição de terras, mas desenvolver um sistema de produção altamente produtivo. Como qualquer empresa constituída no Brasil, a O Telhar tem também compromisso com o cumprimento da legislação em todos os seus aspectos'." "45 (grifo meu)

Entretanto, o Ministério Público do Trabalho e o Ministério do Trabalho e Emprego investigaram a empresa e constataram o procedimento ilícito, pois, esta buscava

\footnotetext{
"vantagens comerciais através da adoção de condições ilegais e desumanas de trabalho (terceirização ilícita, condições degradantes e jornada exaustiva, que são atributos do crime de submissão de pessoas às condições análogas a de escravo previsto no art. 149 do Código Penal). 'A empresa El Telhar, sem sombra de dúvidas, pelos relatórios de fiscalização realizados em várias de suas propriedades pratica o 'dumping social' e causa dano à sociedade, tanto de trabalhadores
}

\footnotetext{
45 http://www.pelegrino.info/noticias/ver/2010/04/23/empresa-argentina-instalada-em-mato-grosso-einvestigada-pelo-mpt-devido-a-fraudes-trabalhistas - Acessado em 03/08/2011, às 22:17hs.
} 
quanto de produtores rurais, pois esse procedimento adotado configura ato ilícito, por exercício abusivo do direito, já que extrapola os limites econômicos e sociais constitucionalmente garantidos', disse o Procurador-chefe do MPT em Mato Grosso, José Pedro dos Reis ... O MPT constatou ainda o desrespeito às condições mínimas de saúde e segurança do trabalho. A fraude trabalhista cometida pela empresa, que se utiliza de terceirização, gera também outro problema de ordem econômica para o Estado que é a concorrência desleal. 'Essa conduta é uma ameaça à ordem econômica e social, como também coloca em risco todo o esforço e os resultados obtidos pelo MPT no MT, visando regularizar as relações de emprego no meio rural, como o combate ao trabalho análogo a de escravo, o combate ao trabalho infantil, a melhoria do meio ambiente de trabalho, entre outros, além de comprometer o cumprimento da Agenda da OIT, implantada em 2008 e que tem como meta consolidar o trabalho decente no MT até 2014, como se não bastasse tudo isso, tal conduta configura um atentado contra a soberania do Estado', destacou o Procurador-chefe do MPT em Mato Grosso, José Pedro dos Reis." ${ }^{46}$ (grifo meu)

Esta última empresa arrolada, El Tejar, confirma plenamente que o agronegócio de moderno só tem a tecnologia, pois suas relações sociais de produção continuam entre a barbárie e o agrobanditismo. Além, disso a questão da aquisição de terras por estrangeiros, está se fazendo em sua maior parte, como as empresas analisadas revelam, pela aliança entre a burguesia brasileira e a burguesia mundial, resolvendo os limites da questão legal, embora eles também pudessem ser ultrapassados pelos estrangeiros, como já se demonstrou neste texto.

A última novidade a vir a público nesse setor da produção de grãos, foi a decisão do grupo AMAGGI (André Maggi), em expandir seus negócios na Argentina onde também, vai plantar soja:

"O empresário e senador Blairo Maggi, um dos maiores produtores de soja do mundo, resolveu expandir seus negócios para a Argentina. No ano passado, seu grupo, o André Maggi (AMaggi), abriu um escritório no país, e em abril deste ano começou a operar como exportadora do grão. Agora, avança mais um passo: vai começar a plantar soja em solo argentino. O grupo deve começar o cultivo em uma área arrendada de 5 mil hectares.Mas, segundo informações que circulam no mercado argentino, o objetivo seria chegar aos 30 mil hectares nos próximos anos. No Brasil, o grupo tem uma produção média anual de 400 mil toneladas de soja, 300 mil toneladas de milho e 20 mil toneladas de algodão. Para Blairo Maggi, o negócio se justifica porque a Argentina é o terceiro maior país produtor de soja do planeta - atrás dos Estados Unidos e do Brasil - e um dos principais players no mercado mundial do agronegócio. Mas ele negou que o grupo tenha sido atraído pelos gastos menores. Segundo o empresário, "há uma

\footnotetext{
${ }^{46}$ Ibidem
} 
grande diferença no custo operacional, que é menor em solo argentino". Mas, quando se leva em conta outros custos, como o de arrendamento da terra, os gastos praticamente se equivalem. Para analistas argentinos, a expansão de "el rey de la soja" para a Argentina é um sinal do processo de internacionalização de seu grupo empresarial. Javier Bujan, presidente da Câmara Arbitral da Bolsa de Cereais da Argentina, disse não se surpreender com a chegada de Maggi ao país. "Minha pergunta seria: o que os produtores argentinos vão fazer no Brasil?", disse, com ironia, em referência à ida de diversos empresários do setor, entre eles Gustavo Grobocopatel, do grupo Los Grobo, que investe no Brasil há quase meia década." (O ESTADO DE SÃO PAULO, 13/08/2011:B17) (grifo meu)

\section{O futuro da questão da reforma agrária e da aquisição de terras por estrangeiros no início do governo do PT de Dilma Rousseff}

O governo Dilma Rousseff iniciou-se sob o signo de que o desenvolvimento capitalista mundializado no país, vai ser aprofundando e, como se fosse possível, a bandeira da reforma agrária esquecida. Basta lembrar sua proposta de governo de subordinar a reforma agrária ao plano de erradicação dos miseráveis da sociedade brasileira eufemisticamente denominados de "pobreza extrema" ou "extrema pobreza".

As entrevistas do novo ministro do Desenvolvimento Agrário, Afonso Florence, da mesma facção de Guilherme Cassel e Miguel Rossetto - DS (Democracia Socialista) do PT - tem revelado que o discurso do início do governo de Luiz Inácio não mudou, ou seja, continua-se o discurso da reforma agrária de qualidade e sua despolitização, o que é mais terrível, e, como se isso fosse possível.

Eis as palavras do novo ministro em entrevista ao jornal Valor Econômico:

"a orientação do governo é fazer a reforma agrária nos termos da necessidade do país, tanto dos demandantes de terra para morar e trabalhar quanto da nação, que precisa de estabilidade demográfica rural, produção de alimentos e paz no campo. O país tem experiência de governos anteriores ao presidente Lula, e não só do governo Lula, que a reforma agrária passa pelo monitoramento da dinâmica do agrário e do fundiário, mas tem a dimensão produtiva, da industrialização e da comercialização. Estamos, nesse momento em que economia nacional vive um crescimento, experimentando um redesenho do rural. A reforma agrária continua na pauta como prioridade do governo e da sociedade, mas ganhando significado correspondente a essa nova dinâmica do rural. Regiões antes deprimidas agora têm novas atividades. Regiões de pecuária agora produzem etanol ou grãos. Temos como orientação aprofundar a reforma agrária com fortalecimento e aperfeiçoamento do MDA e do INCRA, mas buscando essa nova dinâmica.

Valor: Significa mudar o eixo e a localização da reforma? 
Florence: É mudar tudo. Fazer uma reforma onde assentados se insiram em uma dinâmica produtiva, de geração de produção, produtividade, oportunidades, qualidade de vida e alimentos ao país, dentro de um novo contexto econômico e político, posterior aos oito anos de Lula. A liderança agora é da presidenta Dilma. Vamos buscar o bom gasto público, apurar a capacidade de obter terras com qualidade, assentar com qualidade, acelerar o processo de inclusão produtiva. Tudo com responsabilidade fiscal e do aperfeiçoamento da gestão pública, em particular no INCRA.

Valor: Mas ainda cabe a reforma agrária nos dias de hoje?

Florence: Depende de quem pensou e o quê pensou. Tem muitas formulações. Vamos fazer a reforma que o país precisa. Não é para atender luta política. É para garantir acesso à terra a quem nela precisa produzir e viver, garantir produção e produtividade aos assentados, alimentos para nutrir o país e também para conter a inflação. Criar um círculo virtuoso e dinâmico no rural.

\section{Valor: Então, não haverá espaço para ideologia?}

Florence: $\mathrm{O}$ que estou dizendo é ideológico. Ou não é? Esperem em mim a ideologia que a presidenta lidera, não esperem a sua ideologia. Esperem em mim a ideologia da presidenta.

Valor: E a relação com os movimentos sociais do campo?

Florence: Há mecanismos regulares de mediação isonômicos. Os movimentos sociais de luta pela terra e da agricultura familiar encontram no MDA e no INCRA mecanismos permanentes de mediação. Além disso, a presidenta Dilma determinou a consolidação dos processos de negociação, em todas as áreas, sob coordenação da Secretaria-Geral da Presidência, do ministro Gilberto Carvalho. A pauta dos movimentos contêm muitos itens de responsabilidade de outros ministérios. Não é só terra.

\section{Valor: Mas isso não esvazia o MDA?}

Florence: Pelo contrário. O papel do MDA é executar a política pública de reforma agrária e da agricultura familiar, e não negociar com os movimentos. Essa é uma função fundamental, mas não é atribuição legal da política pública que nós temos. A mediação é da Secretaria-Geral, como o ministro Luiz Dulci já fazia. Vamos aperfeiçoar mecanismos de negociação com os movimentos, mas coordenar, elaborar a política pública, gerir o fundiário nacional e fazer a reforma agrária e a organização produtiva. Vamos dar muita atenção à capacidade de produção e produtividade nos assentamentos da reforma agrária." (VALOR ECONÔMICO, 22/06/2011:E1) (grifo meu)

Mas, voltando a questão da aquisição de terras por estrangeiros, como já tratei neste texto, a ação do lobby dos setores sucroenergético e de silvicultura (O ESTADO DE SÃO PAULO, 30/03/2011:A6) já está encontrando eco no novo governo do Partido dos Trabalhadores de Dilma Rousseff. O eco nasce da sensibilidade favorável que o PT passou a ter com entrada do capital mundial no país. A Agência Estado em abril deste ano, já dava a senha em reportagem com a seguinte manchete "Limite de aquisição de terras por estrangeiro barrou entrada de US\$15 bi no País" vinda de estudo das 
empresas de consultorias MBAgro e Agroconsult encomendado pela Associação Brasileira de Marketing Rural e Agronegócios (ABMR\&A):

"pelo menos US\$ 15 bilhões teriam deixado de entrar no Brasil desde agosto do ano passado, quando a Advocacia Geral da União (AGU) emitiu parecer restringindo à aquisição de terras por empresas estrangeiras ... Para os autores do estudo, à aquisição de terras por estrangeiros no País não afeta a soberania nacional e sua restrição vai prejudicar a velocidade do crescimento do agronegócio no ritmo exigido pela crescente demanda mundial por alimentos. 'O Brasil sempre dependeu de capital externo. Restringir a compra de terras agora implica reduzir a velocidade do crescimento do agronegócio nos próximos anos, já que a restrição imposta pela $A G U$ traz dificuldades de captação de recursos', diz André Pessôa, sócio-diretor da Agroconsult. 'A consequência de o Brasil ter esse crescimento mais lento é o aumento dos preços internacionais. Além disso, tira a oportunidade de desenvolvimento social de locais mais pobres que não têm outra alternativa.' $\mathrm{Na}$ avaliação de Pessôa, a restrição brasileira passa um 'recado muito ruim' para o mundo, já que em rodadas internacionais de negócios o País defende abertura dos mercados. A participação do capital internacional, destaca o estudo, não se restringe apenas à aquisição direta das terras. Se estende ao financiamento da produção, seja por meio dos bancos estrangeiros que concedem créditos; das tradings que antecipam recursos para pagamento após a colheita; e das multinacionais fabricantes de fertilizantes e defensivos, que realizam operações de trocas de insumos por produtos. Segundo Pessôa, o Brasil precisaria nos próximos 10 anos de $\mathrm{R} \$ 93,5$ bilhões em investimentos para atender a demanda mundial por grãos, considerando uma situação de estoques no mesmo nível de hoje, para evitar pressão adicional sobre os preços. Metade desse investimento seria de capital estrangeiro, diz o analista. Desse total, os setores de grãos e algodão precisariam de $\mathrm{R} \$ 31,2$ bilhões (R \$ 13,6 bi para compra de terras e R \$ 17,6 bi para formação de lavouras e infraestrutura). Já a área de cana tem uma demanda de $\mathrm{R} \$ 43,8$ bilhões ( $\mathrm{R} \$ 24,5$ para aquisição de terras e $\mathrm{R} \$ 19,2$ bilhões para formação de lavouras e infraestrutura) e a de florestas outros R $\$$ 18,5 bilhões ( $\mathrm{R} \$ 7,9$ bilhões para terras e $\mathrm{R} \$ 10,6$ bilhões para infraestrutura). Isso tudo para uma expansão na próxima década de 5,5 milhões de hectares em grãos e algodão, 3,1 milhões de hectares em cana e 2,6 milhões de hectares em reflorestamentos. A título de comparação, o analista lembra que na década de 80 o Brasil tinha 34 milhões de hectares plantados com grãos, área que cresceu pouco menos de 5 milhões de hectares em 30 anos, atingindo 38,9 milhões de hectares em 2010. 'Para mim essa evolução nos últimos 30 anos é uma demonstração de que o capital nacional não resolveu $o$ problema. Portanto, o Brasil não pode prescindir de receber esse capital externo', completou Pessôa. Em relação à soberania brasileira, um dos pontos levantados pelo governo, Pessôa diz não ver nenhuma ameaça proveniente dos investimentos estrangeiros em terras no Brasil. 'A terra, se bem explorada, é um ativo sustentável e renovável, e é imóvel. Não dá para levar embora. Então vai gerar desenvolvimento aqui. E a própria produção será brasileira, regida pelas leis daqui', completou Pessôa. 'Como consultores, nossa visão é 
que em nenhum momento o investimento do capital externo no ativo terra seria um problema nos aspectos trabalhistas, judiciais e da própria propriedade da terra. Eles serão obrigados a seguir a legislação. Só haveria problema se existisse uma regra para brasileiro e outra para estrangeiro."'"77 (grifo meu)

Na mesma reportagem Marcos Jank, presidente da União da Indústria de Canade-açúcar (Unica) também lembrou que

\begin{abstract}
"o setor sucroalcooleiro foi bastante afetado pela crise econômica de 2008, e que parte da consolidação após esse momento se deu graças a capital estrangeiro, como a criação da joint venture entre Cosan e a Shell, à aquisição da Equipav e da Vale do Ivaí pela indiana Shree Renuka e a compra da Santa Elisa Vale pela Louis Dreyfus. 'Isso foi muito saudável para o processo de reestruturação do setor. Mas agora esse parecer pode afetar a área de arrendamento de terras, que é tão importante para o setor de cana', disse o executivo." ${ }^{48}$ (grifo meu)
\end{abstract}

Ou seja, a aliança de classe entre a burguesia brasileira e a mundial não é apenas retórica, mas aliança de classe de fato. Alias, é por isso mesmo, que a questão depois do Parecer CGU/AGU N $01 / 2008-R V J$, de 23/08/2010, passou a ser sua interferência na lógica da aliança de classe e do processo produtivo do capitalismo mundializado. $\mathrm{O}$ lobby e as reclamações midiáticas já levaram do governo Dilma Rousseff a criar grupo de trabalho coordenado pela Secretaria de Assuntos Estratégicos (SAE).

$\mathrm{O}$ assunto foi veiculado pelo jornal O Estado de São Paulo em reportagem que tinha como manchete "Limite de terras para estrangeiro é obstáculo". Nesta matéria começam a aparecer as novas possibilidades legais para que a legislação sobre terras a estrangeiros vá sendo adaptada à nova ordem mundial. Contraditoriamente, a arguta repórter Marta Salomon preferiu identificar apenas diferenças entre a gestão de Luiz Inácio e da Dilma Rousseff:

"os limites impostos para a compra ou o arrendamento de terras por
estrangeiros no País são apontados pelo grupo de trabalho coordenado
pela Secretaria de Assuntos Estratégicos (SAE) como o principal
obstáculo à captação de dinheiro para plantar florestas no Brasil. O
diagnóstico reflete um choque de políticas no governo federal. Desde
o final do mandato de Luiz Inácio Lula da Silva, a Advocacia-Geral
da União (AGU) vem fechando brechas à compra de terras por
estrangeiros acima dos limites fixados nos anos 70 . Na última
segunda-feira, a presidente Dilma Rousseff discutiu novos limites ao
avanço de estrangeiros sobre terras no País, segundo informou o
Estado. O movimento do governo paralisou a captação de dinheiro

\footnotetext{
${ }^{47} \mathrm{http}: / /$ economia.estadao.com.br/noticias/not_63309.htm - Acessado dia 25/06/2011, às 10:05hs.

${ }^{48}$ Ibidem.
} 
estrangeiro em Fundos de Investimentos em Participações (FIP), segundo informações do projeto que prevê a transformação do Brasil em 'potência florestal'. Esses fundos já haviam captado R\$ 4 bilhões para participação em projetos florestais em 2009, valor que seria suficiente para financiar o plantio da maior parte da meta de 1 milhão de hectares de novas florestas por ano. 'Tendo em vista a importância dos investimentos a serem financiados pelos fundos em participações que captem recursos no exterior para a expansão das florestas plantadas, a presidente da República deverá excepcionalizar os empreendimentos florestais considerados de interesse para o desenvolvimento nacional', propõe o estudo. Os investimentos previstos para tirar do papel o projeto de 'potência florestal' chegam a US\$ 100 bilhões em uma década. A maior parte seria destinada a instalações industriais apropriadas aos vários usos da madeira, da produção de papel e móveis à geração de bioenergia. Outro obstáculo na legislação referese ao Código Florestal, cuja reforma é debatida no Congresso Nacional. Empresários do setor defendem o reconhecimento de florestas já plantadas em topo de morro e o reflorestamento de áreas desmatadas no sul da Amazônia com espécies exóticas. O documento apóia a reivindicação. $\mathrm{Na}$ área ambiental, o maior obstáculo é a simplificar o licenciamento florestal e ambiental, descrito como 'burocrático e com excesso de normas' pelo próprio estudo. 'Propõe-se que as florestas plantadas em áreas privadas devem ser tratadas como os demais cultivos agrícolas, para efeitos de manejo e corte', afirma o projeto. $\mathrm{O}$ documento defende dispensar o licenciamento para o plantio em áreas até 1 mil hectares ou 10 quilômetros quadrados." (O ESTADO DE SÃO PAULO, 20/03/2011:A2A) (grifo meu)

Dessa forma, o governo brasileiro vai mais uma vez propor nova lei para regular à aquisição de terras por estrangeiros, inclusive, segundo também o jornal O Estado de São Paulo informou que a
"proposta de projeto de lei a que o Estado teve acesso estabelece novos limites em módulos fiscais - medida que varia de município para município, entre 5 e 100 hectares. Pessoas físicas poderão ter até 15 módulos fiscais, sem precisar de aval prévio do Congresso Nacional. Pessoas jurídicas - inclusive empresas brasileiras com controle de capital ou gestão em mãos de estrangeiros - poderão comprar ou arrendar até 30 módulos, em áreas contínuas ou não." ${ }^{49}$ (grifo meu)

A notícia trouxe também a indicação de que a proposta do projeto de lei já nascera no final do governo de Luiz Inácio:

"a proposta foi elaborada por grupo de trabalho coordenado pela Advocacia-Geral da União (CGU) no segundo mandato do expresidente Luiz Inácio Lula da Silva. Integrado também pelo Gabinete de Segurança Institucional (GSI) e pelos Ministérios da Defesa e do

\footnotetext{
${ }^{49} \mathrm{http} / /$ www.estadao.com.br/estadaodehoje/20110317/not_imp693076,0.php - Acessado em 25/06/2011, ãs $10: 22 \mathrm{hs}$.
} 
Desenvolvimento Agrário, o grupo chegou a cogitar a edição de uma medida provisória. Mas a campanha eleitoral deixou o assunto em suspenso na agenda do governo. Dilma Rousseff, ainda chefe da Casa Civil na época, recebeu cópia da proposta. Depois de assumir a Presidência da República, ainda não indicou quando o texto irá ao Congresso. O governo Dilma mantém a avaliação de que a compra e o arrendamento de terras no Brasil continuam crescendo e fogem ao controle dos cadastros oficiais."

O jornal O Estado de São Paulo também obteve acesso à proposta do projeto de lei que estabelece que

"empresas e pessoas estrangeiras que quiserem comprar terras no Brasil com área superior a 5 hectares terão de pedir autorização do governo. A compra de áreas até 500 mil hectares será avaliada e autorizada por um órgão especial, o Conselho Nacional de Terras (Conater). Acima de 500 mil hectares, a compra precisa ser aprovada pelo Congresso. Nos dois casos, a minuta do projeto de lei em estudo no governo para definir 'limites à aquisição de imóveis rurais por estrangeiros', diz que 'pessoa física estrangeira residente no país e pessoa jurídica estrangeira autorizada a funcionar no País' terá de construir uma Sociedade de Propósito Específico (SPE) para comprar as terras e oferecer uma golden share ao governo. Na prática, significa que o governo será sócio de todos os negócios agrícolas de estrangeiros. Golden share é uma ação especial que a SPE oferece ao governo como forma de ele participar das decisões estratégicas da empresa - concedendo-lhe, inclusive, o direito de veto na decisões. Pessoas físicas estrangeiras e empresas estrangeiras que não estejam autorizadas a funcionar no País simplesmente não poderão comprar terras. Empresa brasileira controlada direta ou indiretamente por estrangeiros ou que receba recursos de fundos estrangeiros de investimentos também ficarão submetidas às regras da nova lei." ( $O$ ESTADO DE SÃO PAULO, 22/06/2011:A8) (grifo meu)

Entretanto, como é recorrente no Estado brasileiro em relação aos interesses internacionais desde a ditadura militar, um assessor da presidente Dilma Rousseff tratou logo de explicar que o projeto de lei "não vai criar nenhuma barreira para os investimentos estrangeiros". (O ESTADO DE SÃO PAULO, 22/06/2011:A8) Disse também que seu objetivo "é criar um instrumento de controle e uma supervisão do Estado sobre o uso da terra". (O ESTADO DE SÃO PAULO, 22/06/2011:A8) E, que ela "será 'bem curta' e com 'regras claras', evitando que haja uma área limite em cada região do País para a notificação da compra ao poder público." (O ESTADO DE SÃO PAULO, 22/06/2011:A8) (grifo meu)

Por fim, cabe destacar a informação óbvia e recorrente na história recente do país, não há limite no Brasil para a propriedade privada capitalista da terra seja ela de

\footnotetext{
${ }^{50}$ Ibidem
} 
brasileiros ou de estrangeiros, ou seja, os estrangeiros poderão adquirir até $500 \mathrm{mil}$ hectares sob aprovação do novo órgão a ser criado Conater, ou se preferirem podem ir a Congresso Nacional que em nome do "desenvolvimento e da geração de emprego", aprovarão propostas de um, dois ou mais milhões de hectares, como fez a ditadura militar quando do Projeto Jari do multimilionário Daniel K. Ludwig, aprovando mais de 5 milhões de hectares.

A reportagem termina com justificativas das assessorias do governo que são pérolas dos vendilhões da pátria como diria Leonel Brizola:

"se a compra envolve investimento, então, o Estado tem de fazer uma
administração estratégica das terras vendidas a estrangeiros"
afirmou um assessor do Ministério do Desenvolvimento Agrário
(MDA). Enquanto isso, um outro assessor do Ministério da
Agricultura destacou como "exemplo da 'administração estratégica' o
interesse de o governo incentivar investimentos que aumentem a
produção do etanol. Nesse caso, explicou, o 'Conselho de Terras' pode
aprovar que uma empresa estrangeira no Brasil ou uma empresa
nacional sob controle estrangeiro compre 'milhares de hectares'." (O
ESTADO DE SÃO PAULO, 22/06/2011:A8) (grifo meu)

A banca ruralista do Congresso Nacional ouvida sobre a proposta foi curta e direta: "É um equívoco" afirmou Lira Maia (DEM-PA) presidente da Comissão de Agricultura da Câmara dos Deputados e, Duarte Nogueira, líder do PSDB também na Câmara dos Deputados e da região de Ribeirão Preto o coração do setor sucroenergético disparou "o governo deve regular, pode participar, mas não tem que mandar" ... "O governo entrar para tomar conta não parece uma boa idéia." (O ESTADO DE SÃO PAULO, 22/06/2011:A8)

Se já não bastasse essas propostas legislativas em tramitação ou não, no Congresso Nacional, a elas juntam-se a proposta de emenda à Constituição sobre a faixa de fronteira já indicada neste texto, a também proposta de emenda à Constituição para alterar a legislação sobre a faixa de marinha:

\footnotetext{
"O presidente do CRECI-SE, Aurélio Cápua Dallapícula ... explicou que há uma Proposta de Emenda à Constituição, a PEC 53, de autoria do senador Almeida Lima, que visa a extinção das enfiteuses, especialmente as que estão no domínio de pessoas que as utilizam exclusivamente para fins residenciais. 'Acredito que, em termos de arrecadação, os valores sejam infimos para o Governo em relação ao PIB do País. A única justificativa plausivel para a manutenção dessas áreas é porque existe uma lei. Então, altera-se essa lei e resolve-se o problema. Essa é a nossa proposta'." (O ESTADO DE SÃO PAULO, 06/08/2011:B16) (grifo meu)
} 
Junta-se também, ao debate que culminou com a aprovação pela Câmara de Deputados de um projeto de lei que praticamente destrói o Código Florestal existente em nome do agronegócio, uma nova campanha do agrobanditismo liderado pelo deputado Moreira Mendes (PPS/RO), presidente da frente parlamentar da agropecuária, que "anunciou uma 'grande campanha' para impedir que novas Unidades de Conservação sejam criadas sem a prévia autorização do Congresso Nacional ... 'Daqui a pouco, do jeito que está, não sobra nada para a produção', reclamou Moreira Mendes ... O colega Valdir Colatto (PMDB-SC) fez coro: 'Daqui a pouco, o Brasil vira um parque'." (O ESTADO DE SÃO PAULO, 06/08/2011:B16) (grifo meu)

Por fim, a benção mor do agronegócio brasileiro sobre a questão da aquisição de terras por estrangeiros, apareceu no texto da presidente da Confederação da Agricultura e Pecuária do Brasil, senadora Kátia Abreu (DEM/TO) mostrando o apoio total da burguesia agrária brasileira à mundialização da economia capitalista e à aquisição de terras por estrangeiros:

\footnotetext{
"A presença de cidadãos e empresas estrangeiras deve ser saudada como algo inteiramente positivo. Numa sociedade em rápida transformação, como a nossa, a economia, a política e a cultura nunca evoluem no mesmo passo. A economia pode modernizar-se rapidamente sob a pressão dos contatos com o exterior, sem que o sistema político e as idéias na sociedade acompanhem-na no mesmo ritmo. A falta de sincronia entre essas esferas da vida social transmite a impressão de que o país vive simultaneamente em tempos históricos diferentes. ... A pior dessas idéias é o nacionalismo. É um nacionalismo mais recatado e fino, sem os slogans patéticos dos anos 50, mas mesmo assim carregado do mesmo veneno. Os nacionalismos de todos os tipos estão na origem dos maiores desastres e dos maiores fracassos das sociedades humanas nos últimos cem anos ... Trazem à tona os piores instintos humanos, como o estranhamento e o ódio ao outro, instintos duramente domados pelos processos civilizatórios, mas que vez por outra ressurgem nas idéias políticas. Essas reflexões me vem à mente com as notícias de que a Advocacia Geral da União está preparando uma proposta de lei determinando que empresas estrangeiras ou empresas nacionais com controle estrangeiro tenham que submeter previamente a um conselho do governo federal a compra de terras acima de cinco hectares. Se esse propósito se concretizar, estaremos diante de um imenso retrocesso, que nos remete de volta ao pior nacionalismo dos anos 50 e dos anos de governo militar. A presença de cidadãos e empresas estrangeiras no desenvolvimento brasileiro deve ser saudada como algo inteiramente positivo e não ser colocada sob suspeita ou restrições." (FOLHA DE SÃO PAULO, 09/07/2011:2) (grifo meu)
} 
É por isso que no Brasil, o debate sobre a propriedade capitalista da terra, quer seja ela de brasileiros ou estrangeiros, continua a não ser feita sob o signo da legislação atual no Brasil: a função social da terra. Dessa forma, a Campanha Nacional pelo Limite da Propriedade da Terra não encontra eco nem nas elites e muito menos no governo do PT. O problema é que os movimentos sócioterritoriais e sindicais arriaram a bandeira da luta pela terra e pela reforma agrária. Talvez, por ironia da história, a barbárie presente na luta dos posseiros possa trazer de novo para a agenda política do país o preceito constitucional da função social da terra e com ela o debate sobre a necessidade da reforma agrária, e, um freio na sanha do agronegócio brasileiro mundializado contra a apropriação das terras públicas.

Assim, se entenderá que a questão da aquisição de terras por estrangeiros no governo de Luiz Inácio foi mesmo uma farsa muito bem montada, pois os maiores latifundiários do mundo moram ao lado de nós brasileiros e são brasileiros. Logo para os defensores da reforma agrária não é demais lembrar sempre desse recado: o inimigo mora ao lado. Ou talvez, lembrar os versos de Cazuza e Arnaldo Brandão:

Tuas idéias não correspondem aos fatos O tempo não para

Eu vejo o futuro repetir o passado Eu vejo um museu de grandes novidades O tempo não para ${ }^{51}$

\section{BIBLIOGRAFIA}

ALVIM, A. M. (2009) Investimentos estrangeiros diretos e suas relações com os processos, causas e efeitos da concentração e estrangeirização das terras no Brasil. Projeto de cooperação técnica "Apoio às políticas e à participação social no desenvolvimento rural” (PCT IICA/NEAD), Brasília, NEAD, (relatório de pesquisa).

AREZKI, R., K. DEININGER, e H. SELOD. 2010. "Interest in Large-Scale Land Acquisition for Agribusiness Investment: Extent and Determinants and the 'Global Land Grab.'” Policy Research Working Paper,World Bank, Washington, DC.

BANDEIRA, M. (1977) "O governo João Goulart - Lutas sociais no Brasil", Civilização Brasileira, Rio de Janeiro.

BRAUN, J. von, e R. MEINZEN-DICK. 2009. “'Land Grabbing' by Foreign Investors in Developing Countries: Risks and Opportunities." Policy Brief 13, International Food Policy Research Institute, Washington, DC.

\footnotetext{
${ }^{51}$ CAZUZA e ARNALDO BRANDÃO "O tempo não para".
} 
COTULA, L., S. VERMEULEN, R. LEONARD, e J. KEELEY. 2009. "Land Grab or Development Opportunity? Agricultural Investment and International Deals in Africa." International Institute for Environment and Development, Food and Agricultural Organization of the United Nations, and International Fund for Agricultural Development, London and Rome.

FERNANDES, B. M. (2011) Estrangeirização de terras na nova conjuntura da questão agrária, in Conflitos no Campo Brasil - 2010, CPT Nacional, Goiânia.

FIAN (Food First Information and Action Network). 2010. "Land Grabbing in Kenya and Mozambique: A Report on Two Research Missions - and a Human Rights Analysis of Land Grabbing." FIAN, Heidelberg.

FOLHA DE SÃO PAULO - 1968, Suplemento Especial 05/05/68, São Paulo.

GARRIDO FILHA, I. (1980) "O projeto Jari e os capitais estrangeiros na Amazônia". Petrópolis, Vozes.

GLAUSE, M. (2009) Extranjeirización del territorio paraguayo, Assunción: Base Investigaciones Sociales.

GRAIN, (2010) Relatório do Banco Mundial sobre a neogrilagem legal de terras: uma decepção e um fracasso http://farmlandgrab.org/15819.

ILC - Internatiotal Land Coalition. (2009) Commercial pressures on land worldwide: issues and conceptual framework. Roma: ILC.

KATUTA, A.M. O processo de estrangeirização no ensino de Geografia, IX Coloquio Internacional de Geocrítica, LOS PROBLEMAS DEL MUNDO ACTUAL. SOLUCIONES Y ALTERNATIVAS DESDE LA GEOGRAFÍA Y LAS CIENCIAS SOCIALES, Porto Alegre, 28 de mayo - 1 de junio de 2007. Universidade Federal do Rio Grande do Sul, in http://www.ub.edu/geocrit/9porto/katuta.htm, Acessado em 16/07/2011, às 23:06hs.

KUGELMAN, M., e S. L. LEVENSTEIN. 2010. "Land Grab? The Race for the World's Farmland." Washington, DC:Woodrow Wilson International Center for Scholars.

LEITE, S.P.; WESZ Jr., V. (2010) Modèle de développement et dynamiques foncières au Brésil: analyse de l'expansion de l'agribusiness du soja et ses effets sur le millieu rural. Montpellier: CIRAD.

LUXEMBURG, Rosa de, (1970) A Acumulação de Capital - estudo sobre a Interpretação Econômica do Imperialismo, Tradução de Moniz Bandeira, Biblioteca de Ciências Sociais, Zahar Editores, Rio de Janeiro.

MACKEY, Lee - Legitimating Foreignization in Bolivia: Brazilian agriculture and the relations of conflict and consent in Santa Cruz, Bolivia, - Paper presented at the International Conference on Global Land Grabbing, 6-8 April 2011, Organised by the Land Deals Politics Initiative (LDPI) in collaboration with the Journal of Peasant Studies and hosted by the Future Agricultures Consortium at the Institute of Development Studies, University of Sussex, England http://www.future-agricultures.org/index.php?option=com_docman..., Acessado em 01/08/2011, às 15:40hs.

MARX, K. (2011) O 18 Brumário de Luís Bonaparte, Boitempo Editorial, São Paulo. 
MERLET, M. (2010) Les appropriations de terres à grande échelle: analyse du phénomène et propositions d'orientations. Paris: Comité Foncier et Développement, junho de 2010.

MOREL, E. (1984) "Amazônia saqueada". São Paulo, Global Editora.

MOREIRA ALVES, Maria Helena, (1985) "Estado e oposição no Brasil,.1964-1984". Vozes, Petrópolis.

NASSAR, A. M. (2010) Terras agrícolas na alça de mira, in http://www.estadao.com.br/estadaodehoje/20101020/not_imp627212,0.php, Acessado em 18/07/2011 às 19:15hs.

OLIVEIRA, A.U. (1987) "Amazônia: monopólio, expropriação e conflitos", Papirus, Campinas.

OLIVEIRA, A.U. (1988) "Integrar para não entregar - Políticas Públicas e Amazônia", Papirus, Campinas.

OLIVEIRA, A.U. (1997) "A Amazônia norte-matogrossense: grilagem, corrupção e violência", Tese de Livre Docência - FFLCH/USP, São Paulo, p. 67/68.

OLIVEIRA, A.U. "Os Agrocumbustíveis e a Produção de Alimentos", in FOLHA DE SÃO PAULO, Tendências e Debates, 17/04/2008, p. 3.

PRETTO, J. M. (2009) Imóveis rurais sob propriedade de estrangeiros no Brasil. Relatório de Projeto de cooperação técnica "Apoio às políticas e à participação social no desenvolvimento rural” (PCT IICA/NEAD), Brasília, NEAD, (relatório de pesquisa).

SAUER, S. (2010) Demanda mundial por terras: "land grabbing" ou oportunidade de negócios no Brasil?, in Revista de Estudos e Pesquisas sobre as Américas, UNB, Brasília, vol.4, No 1/, p. 72/88 (disponível em www.repacm.org).

SAUER, S. e LEITE, S. P. (2010) A estrangeirização da propriedade fundiária no Brasil in

http://www.cartamaior.com.br/templates/materiaMostrar.cfm?materia_id=17268

SAUER, S. e LEITE, S. P. (2011) Agrarian structure, foreign land ownership, and land value in Brazil - Paper presented at the International Conference on Global Land Grabbing, 6-8 April, Organised by the Land Deals Politics Initiative (LDPI) in collaboration with the Journal of Peasant Studies and hosted by the Future Agricultures Consortium at the Institute of Development Studies, University of Sussex, England - http://www.iss.n1/Menupages/Research-Networks/The-LandDeal-Politics-Initiative-LDPI/April-2011-IDS-Sussex2/LDPI-ConferencePapers/Agrarian-structure-foreign-land-ownership-and-land-value-in-Brazil Acessado em 18/07/2011 às 15:05hs

SAUTCHUK, Jaime et alli, (1979) "Projeto Jari-A invasão americana". Ed. Brasil Debates, São Paulo.

SILVA, A.C. (1985) "De quem é o pedaço: Espaço e Cultura", Hucitec, São Paulo.

TAYLOR, M.; BENDING, T. (2009) Increasing commercial pressure on land: building a coordinated response. Roma: ILC.

THE WORLD BANK, (2011) RISING GLOBAL INTEREST IN FARMLAND - Can It Yield Sustainable and Equitable Benefits?, elaborado por Klaus Deininger and 
Derek Byerlee, with Jonathan Lindsay,Andrew Norton, Harris Selod, and Mercedes Stickler, Washington, DC. disponível em www.worldbank.org

\section{ANEXOS}

\section{ATO COMPLEMENTAR N 45, DE 30 DE JANEIRO DE 1969}

O Presidente da República, usando das atribuições que lhe conferem o $\S 1^{\circ}$ do $\operatorname{artigo} 2^{\circ}$ e o artigo $9^{\circ}$ do Ato Institucional $\mathrm{n}^{\circ}$ 5, de 13 de dezembro de 1968, resolve baixar o seguinte Ato Complementar:

Art. $1^{\mathrm{o}}$ À aquisição de propriedade rural no território nacional somente poderá ser feita por brasileiro ou por estrangeiro residente no país.

Parágrafo único. O disposto neste artigo não se aplica aos casos de transmissão causa mortis.

Art. $2^{\circ}$ Para os efeitos deste Ato, considera-se residente no país o estrangeiro que nele possua permanência definitiva.

Art. $3^{\circ}$ Lei especial determinará as condições, restrições, limitações e demais exigências a que ficará sujeita à aquisição de imóvel rural por pessoa estrangeira natural ou jurídica, tendo em vista a defesa da integridade do território nacional, a segurança do Estado e a justa distribuição da propriedade.

Art. $4^{\circ}$ Este Ato Complementar entrará em vigor na data de sua publicação, revogadas as disposições em contrário.

Brasília, 30 de janeiro de $1969 ; 148^{\circ}$ da Independência e $81^{\circ}$ da República.

A. COSTA E SILVA, Luis Antônio da Gama e Silva, Augusto Hamann Rademaker Grünewald, Aurelio de Lyra Tavares, José de Magalhães Pinto, Antônio Delfim Netto, Mario David Andreazza, Ivo Arzua Pereira, Tarso Dutra, Jarbas G. Passarinho, Marcio de Souza e Mello, Leonel Miranda, Antônio Dias Leite Júnior, Edmundo de Macedo Soares, Hélio Beltrão, José Costa Cavalcanti, Carlos F. de Simas (DOU, 31/01/1969).

\section{DECRETO-LEI No 494, DE 10 DE MARÇO DE 1969}

(Regulamenta o Ato Complementar $n^{\circ} 45$, de 30 de janeiro de 1969, que dispõe sôbre à aquisição de propriedade rural por estrangeiro.)

O PRESIDENTE DA REPÚBLICA, no uso das atribuições que lhe confere o $\S 1^{\circ}$ do artigo $2^{\circ}$ do Ato Institucional número 5, de 13 de dezembro de 1968, e tendo em vista o disposto no artigo $3^{\circ}$ do Ato Complementar $\mathrm{n}^{\mathrm{o}}$ 45, de 30 de janeiro de 1969, DECRETA:

Art. $1^{\circ}$ À aquisição de propriedade rural no território nacional somente poderá ser feita por brasileiro ou por estrangeiro residente no País.

$\S 1^{\circ} \mathrm{O}$ disposto neste artigo não se aplica aos casos de transmissão causa mortis.

$\S 2^{\circ}$ Para os efeitos deste Decreto-Lei, considera-se residente no País o estrangeiro que faça prova de fixação permanente no território nacional, de acordo com a legislação em vigor.

$\S 3^{\circ}$ À aquisição de propriedade rural por estrangeiro dependerá de autorização do Ministério da Agricultura, requerida por intermédio do Instituto Brasileira de Reforma Agrária (IBRA).

Art. $2^{\circ}$ - Em caso de aquisição de área rural, a qualquer título, os Tabeliães e Oficiais do Registro de Imóveis farão constar, obrigatoriamente, dos atos que praticarem, os dados relativos ao documento de identidade do adquirente, se for estrangeiro, além da prova de sua residência permanente no território nacional $\left(\S 2^{\circ}\right.$ do artigo $\left.1^{\circ}\right)$.

$\S 1^{\circ}$ - Em se tratando de pessoa jurídica estrangeira, deverão ser transcritos nos atos praticados os dados essenciais comprobatórios de sua constituição e a prova do cumprimento do disposto no artigo $5^{\circ}$ e seu parágrafo único deste Decreto-Lei.

$\S 2^{\circ}-$ Em se tratando de pessoa natural estrangeira, deverá ser transcrita a prova de cumprimento do disposto no artigo $1^{\circ}$ deste Decreto-Lei.

Art. $3^{\circ}$ - Os Oficiais do Registro de Imóveis deverão possuir cadastro especial das aquisições de terras rurais por pessoas estrangeiras naturais ou jurídicas do qual constarão, sob pena de nulidade dos atos que praticarem:

a) documentos de identidade das partes contratantes ou cópias fotostáticas dos mesmos, devidamente autenticadas;

b) memorial descritivo do imóvel, contendo área, características, limites e confrontações;

c) planta do imóvel e respectiva situação relativa na planta cadastral do município;

d) prova de autorização prevista no artigo $6^{\circ}$ e seu parágrafo primeiro e no artigo $7^{\circ}$ deste Decreto-lei. 
Art. $4^{\circ} \mathrm{A}$ inobservância do disposto nas artigos $2^{\circ}$ e $3^{\circ}$ deste Decreto-lei configura o crime de falsidade ideológica, definido no artigo 299 do Código Penal.

Art. $5^{\circ}$ Anualmente, o Desembargador-Corregedor da Justiça Estadual, ou magistrado por ele indicado, e o Procurador da República, que for designado, promoverão, em conjunto, correição nos livros dos Tabeliães e dos Oficiais do Registro de Imóveis de todas as comarcas dos respectivos Estados, para verificar o cumprimento deste Decreto-lei, determinando, de imediato, as providências que forem convenientes.

Parágrafo único. No Distrito Federal e Territórios, as atribuições previstas neste artigo serão exercidas pelo Desembargador-Corregedor da Justiça do Distrito Federal e Territórios.

Art. $6^{\circ}$ A pessoa jurídica estrangeira não poderá adquirir imóvel rural no Brasil, salvo se for autorizada a funcionar no País, devendo as aquisições ser vinculadas aos objetivos estatutários da sociedade.

$\S 1^{\circ}$ À aquisição de imóvel rural por pessoa jurídica estrangeira, no caso deste artigo, depende de autorização concedida por decreto em processo instituído pelo Ministério da Agricultura por intermédio do Instituto Brasileiro de Reforma Agrária (IBRA).

$\S 2^{\circ}$ São equiparadas às pessoas jurídicas estrangeiras, para os efeitos deste Decreto-lei, as pessoas jurídicas nacionais das quais participem, a qualquer título, pessoas estrangeiras naturais ou jurídicas que detenham maioria no seu capital social e residam ou tenham sede no exterior. $\S 3^{\circ}$ As ações de companhias ou sociedades anônimas nacionais, proprietárias de imóveis rurais e que se dediquem ao ramo de

comércio mobiliário, revestirão, obrigatòriamente, a forma nominativa.

Art. $7^{\circ}$ À aquisição, por pessoa estrangeira natural ou jurídica, de glebas rurais situadas nos Municípios de interesse da segurança nacional e nas áreas a esta consideradas indispensáveis (Constituição, artigo 16, § $1^{\circ}$, b e artigo 91, II e parágrafo único), depende de prévia autorização do Conselho de Segurança Nacional.

Art. $8^{\circ} \mathrm{A}$ soma das áreas rurais pertencentes a pessoas estrangeiras naturais e jurídicas em todo o território nacional, inclusive na área de que trata a Lei $\mathrm{n}^{\circ} 2.597$, de 12 de setembro de 1955 , não poderá ultrapassar:

a) nos municípios de até $10.000 \mathrm{~km} 2,1 / 5$, da respectiva área;

b) nos municípios de mais de $10.000 \mathrm{~km} 2$ a $50.000 \mathrm{~km} 2,1.000 \mathrm{~km} 2$, mais $1 / 10$ da respectiva área;

c) nos municípios de mais de $50.000 \mathrm{~km} 2$ até $100.000 \mathrm{~km} 2,3.500 \mathrm{~km} 2$ mais $1 / 20$ da respectiva área;

b) nos municípios de mais de $100.000 \mathrm{~km} 2,6.000 \mathrm{~km} 2$ mais $1 / 40$ da respectiva área.

$\S 1^{\circ}$ As pessoas de uma mesma nacionalidade não poderão possuir mais de $20 \%$ dos limites estabelecidos neste artigo.

$\S 2^{\circ}$ Atingidos esses limites, são vedadas, aos Tabeliães, a lavratura de novas escrituras e, aos Oficiais do Registro de Imóveis, a efetuação de novas transcrições, sob as cominações do artigo 17, deste Decreto-lei. Art. $9^{\circ}$ Os Tabeliães e Oficiais do Registro de Imóveis ficam obrigados, dentro de 30 (trinta) dias da prática do ato, a comunicar ao Ministério da Agricultura, por intermédio do Instituto Brasileiro de Reforma Agrária (IBRA), a lavratura de escrituras e registros imobiliários pelos quais se transfiram, a qualquer título, a posse ou a propriedade de imóveis rurais a pessoas estrangeiras, naturais ou jurídicas.

Parágrafo único. Quando se tratar de imóveis rurais situados em áreas consideradas indispensáveis à segurança nacional ou de seu interesse, a comunicação será feita também à Secretaria Geral do Conselho de Segurança Nacional.

Art. 10. Na aquisição, a qualquer título, de imóveis rurais por pessoa estrangeira natural ou jurídica, é da essência do ato a escritura pública.

Art. 11. Fica a União autorizada, por motivo de segurança nacional, a desapropriar terras rurais em poder de pessoa estrangeira natural ou jurídica, mediante decreto, ouvido, prèviamente, o Conselho de Segurança Nacional.

Art. 12. O artigo 60 da Lei número 4.504, de 30 de novembro de 1964, passa a vigorar com a seguinte redação:

"Art. 60. Para os efeitos desta lei, consideram-se empresas particulares de colonização as pessoas naturais, nacionais ou estrangeiras, residentes e domiciliadas no Brasil, ou jurídicas, constituídas e sediadas no País, que tiverem por finalidade executar programas de valorização de área ou distribuição de terras".

Art. 13. São equiparadas aos brasileiros, para os efeitos deste Decreto-lei, as pessoas naturais de nacionalidade portuguesa residentes no Brasil.

Art. 14. Ao Ministério da Agricultura, por intermédio do Instituto Brasileiro de Reforma Agrária (IBRA), fica atribuída a execução deste Decreto-lei.

Parágrafo único. Nas zonas indispensáveis à segurança nacional e nas áreas consideradas do seu interesse, a Secretaria-Geral do Conselho de Segurança Nacional, por meio da Comissão de Faixa de Fronteiras, exercerão as atribuições previstas neste artigo. 
Art. 15. Salvo nos casos previstos em legislação de núcleos coloniais onde se estabeleçam estrangeiros imigrantes agricultores, em lotes rurais, é vedada, a qualquer título, a doação, posse ou venda de terras pertencentes à União ou aos Estados, a pessoas estrangeiras naturais ou jurídicas.

Art. 16. Em todo e qualquer caso de aquisição de imóvel rural por pessoa estrangeira natural ou jurídica, ou a esta equiparada para os efeitos deste Decreto-lei, no processo instaurado pelo Ministério da Agricultura, será ouvida, obrigatòriamente, a Procuradoria Geral da República que tomará ex ofício, de imediato, as providências que se fizerem necessárias à defesa dos interesses da União.

Art. 17. As alienações e aquisições de propriedades rurais feitas em desacordo com as normas deste Decreto-lei, assim como as que se fizerem a estrangeiros no exterior, são nulas de pleno direito, sujeitando-se os Tabeliães e Oficiais, que lavrarem ou transcreverem os atos respectivos, as penas do crime definido no art. 319 do Código Penal, além da perda do cargo.

Art. 18. O Poder Executivo baixará, dentro de 30 dias, a regulamentação necessária à execução deste Decreto-lei.

Art. 19. Este Decreto-lei entrará em vigor na data de sua publicação, revogadas as disposições em contrário.

Brasília, 10 de março de 1969; $148^{\circ}$ da Independência e $81^{\circ}$ da República.

Costa e Silva, Luís Antonio da Gama e Silva, Ivo Arzua Pereira (D.O.U. de 11.3.1969)

\section{LEI N ${ }^{\circ}$ 5.709, DE 7 DE OUTUBRO DE 1971}

(Regula à aquisição de imóvel rural por estrangeiro residente no País ou pessoa jurídica estrangeira autorizada a funcionar no Brasil e dá outras providências.)

O PRESIDENTE DE REPÚBLICA,

Faço saber que o Congresso Nacional decreta e eu sanciono a seguinte Lei:

Art. $1^{\circ} \mathrm{O}$ estrangeiro residente no País e a pessoa jurídica estrangeira autorizada a funcionar no Brasil só poderão adquirir imóvel rural na forma prevista nesta lei.

$\S 1^{\circ}$ Fica, todavia, sujeita ao regime estabelecido por esta Lei a pessoa jurídica brasileira da qual participem, a qualquer título, pessoas estrangeiras físicas ou jurídicas que tenham a maioria do seu capital social e residam ou tenham sede no exterior.

$\S 2^{\circ}$ As restrições estabelecidas nesta Lei não se aplicam aos casos de sucessão legítima, ressalvado o disposto no art. $7^{\circ}$. (Parágrafo com redação dada pela Lei $n^{\circ} 6.572$, de 30/9/1978)

Art. $2^{\circ}$ (Revogado pela Lei $n^{\circ} 6.815$, de 19/8/1980)

Art. $3^{\circ}$ À aquisição de Imóvel rural por pessoa física estrangeira não poderá exceder a 50 (cinqüenta) módulos de exploração indefinida, em área contínua ou descontínua.

$\S 1^{\circ}$ Quando se tratar de imóvel com área não superior a 3 (três) módulos, à aquisição será livre, independendo de qualquer autorização ou licença, ressalvadas as exigências gerais determinadas em lei.

$\S 2^{\circ} \mathrm{O}$ Poder Executivo baixará normas para à aquisição de área compreendida entre 3 (três) e 50 (cinqüenta) módulos de exploração indefinida.

$\S 3^{\circ}$ O Presidente da República, ouvido o Conselho de Segurança Nacional, poderá aumentar o limite fixado neste artigo.

Art. $4^{\circ}$ Nos loteamentos rurais efetuados por empresas particulares de colonização, à aquisição e ocupação de, no mínimo, 30\% (trinta por cento) da área total serão feitas obrigatòriamente por brasileiros. Art. $5^{\circ}$ As pessoas jurídicas estrangeiras referidas no art. $1^{\circ}$ desta Lei só poderão adquirir imóveis rurais destinados à implantação de projetos agrícolas, pecuários, industriais, ou de colonização, vinculados aos seus objetivos estatutários.

$\S 1^{\circ}$ Os projetos de que trata este artigo deverão ser aprovados pelo Ministério da Agricultura, ouvido o órgão federal competente de desenvolvimento regional na respectiva área.

$\S 2^{\circ}$ Sobre os projetos de caráter industrial será ouvido o Ministério da Indústria e Comércio.

Art. $6^{\circ}$ Adotarão obrigatòriamente a forma nominativa as ações de sociedades anônimas:

I - que se dediquem a loteamento rural;

II - que explorem diretamente áreas rurais;

III - que sejam proprietárias de imóveis rurais não vinculados as suas atividades estatutárias.

Parágrafo único. A norma deste artigo não se aplica às entidades mencionadas no art. $4^{\circ}$ do Decreto-lei $n^{\circ}$ 200, de 25 de fevereiro de 1967, com a redação que lhe foi dada pelo Decreto-lei no 900, de 29 de setembro de 1967.

Art. $7^{\circ}$ À aquisição de imóvel situado em área considerada indispensável à segurança nacional por pessoa estrangeira, física ou jurídica, depende do assentimento prévio da Secretaria-Geral do Conselho de Segurança Nacional. 
Art. $8^{\circ} \mathrm{Na}$ aquisição de imóvel rural por pessoa estrangeira, física ou jurídica, e da essência do ato a escritura pública.

Art. $9^{\circ}$ Da escritura relativa à aquisição de área rural por pessoas física estrangeiras constará, obrigatoriamente:

I - menção do documento de Identidade do adquirente;

II - prova de residência no território nacional; e

III - quando for o caso, autorização do órgão competente ou assentimento prévio da Secretaria-Geral do Conselho de Segurança Nacional.

Parágrafo único. Tratando-se de pessoa jurídica estrangeira, constará da escritura a transcrição do ato que concedeu autorização para à aquisição da área rural, bem como dos documentos comprobatórios de sua constituição e de licença para seu funcionamento no Brasil.

Art. 10. Os Cartórios de Registro de Imóveis manterão cadastro especial, em livro auxiliar, das aquisições de terras rurais por pessoas estrangeiras, físicas e jurídicas, no qual deverá constar:

I - menção do documento de identidade das partes contratantes ou dos respectivos atos de constituição, se pessoas jurídicas;

II - memorial descritivo do imóvel, com área, características, limites e confrontações; e

III - transcrição da autorização do órgão competente, quando for o caso.

Art. 11. Trimestralmente, os Cartórios de Registro de Imóveis remeterão, sob pena de perda do cargo, à Corregedoria da Justiça dos Estados a que estiverem subordinados e ao Ministério da Agricultura, relação das aquisições de áreas rurais por pessoas estrangeiras, da qual constem os dados enumerados no artigo anterior.

Parágrafo único. Quando se tratar de Imóvel situado em área indispensável à segurança nacional, a relação mencionada neste artigo deverá ser remetida também à Secretaria-Geral do Conselho de Segurança Nacional.

Art. 12. A soma das áreas rurais pertencentes a pessoas estrangeiras, físicas ou jurídicas, não poderá ultrapassar a 1/4 (um quarto) da superfície dos Municípios onde se situem, comprovada por certidão do Registro de Imóveis, com base no livro auxiliar de que trata o art. 10.

$\S 1^{\circ}$ As pessoas da mesma nacionalidade não poderão ser proprietárias, em cada Município, de mais de $40 \%$ (quarenta por cento) do limite fixado neste artigo.

$\S 2^{\circ}$ Ficam excluídas das restrições deste artigo as aquisições de áreas rurais:

I - inferiores a 3 (três) módulos;

II - que tiverem sido objeto de compra e venda, de promessa de compra e venda, de cessão ou de promessa de cessão, mediante escritura pública ou instrumento particular devidamente protocolado no registro competente, e que tiverem sido cadastradas no INCRA em nome do promitente comprador, antes de 10 de março de 1969 ;

III - quando o adquirente tiver filho brasileiro ou for casado com pessoa brasileira sob o regime de comunhão de bens;

$\S 3^{\circ} \mathrm{O}$ Presidente da República poderá, mediante decreto, autorizar à aquisição além dos limites fixados neste artigo, quando se tratar de imóvel rural vinculado a projetos julgados prioritários em face dos planos de desenvolvimento do País.

Art. 13. O art. 60 da Lei n ${ }^{\circ}$ 4.504, de 30 de novembro de 1964, passa a vigorar com a seguinte redação:

"Art. 60. Para os efeitos desta Lei, consideram-se empresas particulares de colonização as pessoas físicas, nacionais ou estrangeiras, residentes ou domiciliadas no Brasil, ou jurídicas, constituídas e sediadas no País, que tiverem por finalidade executar programa de valorização de área ou distribuição de terras."

Art. 14. Salvo nos casos previstos em legislação de núcleos coloniais, onde se estabeleçam em lotes rurais, como agricultores, estrangeiros imigrantes, é vedada, a qualquer título, a doação, de terras da União ou dos Estados a pessoas estrangeiras, físicas ou jurídicas.

Art. 15. aquisição de Imóvel rural, que viole as prescrições desta Lei, é nula de pleno direito. O tabelião que lavrar a escritura e o oficial de registro que a transcrever responderão civilmente pelos danos que causarem aos contratantes, sem prejuízo da responsabilidade criminal por prevaricação ou falsidade ideológica. O alienante está obrigado a restituir ao adquirente o preço do imóvel.

Art. 16. As sociedades anônimas, compreendidas em quaisquer dos incisos do caput do art. $6^{\circ}$, que já estiverem constituídas à data do início da vigência desta Lei, comunicarão, no prazo de 6 (seis) meses, ao Ministério da Agricultura a relação das áreas rurais de sua propriedade ou exploração.

$\S 1^{\circ}$ As sociedades anônimas, indicadas neste artigo, que não converterem em nominativas suas ações, ao portador, no prazo de 1 (um) ano do início da vigência desta Lei, reputar-se-ão irregulares, ficando sujeitas à dissolução, na forma da lei, por iniciativa do Ministério Público.

$\S 2^{\circ}$ No caso de empresas concessionárias de serviço público, que possuam imóveis rurais não vinculados aos fins da concessão, o prazo de conversão das ações será de 3 (três) anos. 
$\S 3^{\circ}$ As empresas concessionárias de serviço público não estão obrigadas a converter em nominativas as ações ao portador, se dentro do prazo de 3 (três) anos, contados da vigência desta lei, alienarem os imóveis rurais não vinculados aos fins da concessão.

Art. 17. As pessoas jurídicas brasileiras que, até 30 de janeiro de 1969 , tiverem projetos de colonização aprovados nos termos do art. 61 da Lei $\mathrm{n}^{\circ}$ 4.504, de 30 de novembro de 1964, poderão, mediante autorização do Presidente da República, ouvido o Ministério da Agricultura, concluí-los e outorgar escrituras definitivas, desde que o façam dentro de 3 (três) anos e que a área não exceda, para cada adquirente, 3 (três) módulos de exploração indefinida.

Art. 18. São mantidas em vigor as autorizações concedidas, com base nos Decretos-leis n ${ }^{\circ}$ s 494, de 10 de março de 1969, e 924, de 10 de outubro de 1969, em estudos e processos já concluídos, cujos projetos tenham sido aprovados pelos órgãos competentes.

Art. 19. O Poder Executivo baixará dentro de 90 (noventa) dias, o regulamento para execução desta Lei.

Art. 20. Esta Lei entrará em vigor na data de sua publicação.

Art. 21. Revogam-se os Decretos-leis nº 494, de 10 de março de 1969, e 924, de 10 de outubro de 1969, e demais disposições em contrário.

Brasília, 7 de outubro de $1971 ; 150^{\circ}$ da independência e $83^{\circ}$ da República.

EMÍlIO G. MÉDICI, Alfredo Buzaid, L. F. Cirne Lima, Marcus Vinícius Pratini de Moraes (DOU, $11 / 10 / 19710)$.

DECRETO No 74.965, DE 26 DE NOVEMBRO DE 1974

(Regulamenta a Lei $n^{\circ} 5.709$, de 7 de outubro de 1971, que dispõe sobre à aquisição de imóvel rural por estrangeiro residente no País ou pessoa jurídica estrangeira autorizada a funcionar no Brasil.)

O PRESIDENTE DA REPÚBLICA, usando da atribuição que lhe confere o artigo 81, item III, da Constituição, e tendo em vista o disposto no artigo 19, da Lei n ${ }^{\circ} 5.709$, de 7 de outubro de 1971, DECRETA:

Art. $1^{\circ}$. O estrangeiro residente no País e a pessoa jurídica estrangeira autorizada a funcionar no Brasil só poderão adquirir imóvel rural na forma prevista neste regulamento.

$\S 1^{\circ}$ Fica também sujeita ao regime estabelecido por este regulamento a pessoa jurídica brasileira da qual participem, a qualquer título, pessoas estrangeiras, físicas ou jurídicas, que tenham a maioria do seu capital social e residam ou tenham sede no exterior.

$\S 2^{\circ}$ As restrições estabelecidas neste regulamento não se aplicam aos casos de transmissão causa mortis.

Art. $2^{\circ}$. A pessoa estrangeira, física ou jurídica, só poderá adquirir imóvel situado em área considerada indisponível à segurança nacional mediante assentimento prévio da Secretaria Geral do Conselho de Segurança Nacional.

Art. $3^{\circ}$. Na aquisição de imóvel rural por pessoa estrangeira, física ou jurídica, é da essência do ato a escritura pública.

Art. $4^{\circ}$. Compete ao Instituto Nacional de Colonização e Reforma Agrária (INCRA) fixar, para cada região, o módulo de exploração indefinida, podendo modificá-lo sempre que houver alteração das condições econômicas e sociais da região.

Art. $5^{\circ}$. A soma das áreas rurais pertencentes a pessoas estrangeiras, físicas ou jurídicas, não poderá ultrapassar 1/4 (um quarto) da superfície dos Municípios onde se situem comprovada por certidão do Registro de Imóveis, com base no livro auxiliar de que trata o artigo 15.

$\S 1^{\circ}$ As pessoas de mesma nacionalidade não poderão ser proprietárias, em cada Município, de mais de $40 \%$ (quarenta por cento) do limite fixado neste artigo.

$\S 2^{\circ}$ Ficam excluídas das restrições deste artigo as aquisições de áreas rurais:

I - Inferiores a 3 (três) módulos;

II - Que tiveram sido objeto de compra e venda, de promessa de compra e venda, de cessão ou de promessa de cessão, constante de escritura pública ou de documento particular devidamente protocolado na circunscrição imobiliária competente, e cadastrada no INCRA em nome do promitente-comprador, antes de 10 de março de 1969;

III - Quando o adquirente tiver filho brasileiro ou for casado com pessoa brasileira sob o regime de comunhão de bens.

$\S 3^{\circ}$ Será autorizada por Decreto, em cada caso, à aquisição além dos limites fixados neste artigo, quando se tratar de imóvel rural vinculado a projetos julgados prioritários em face dos planos de desenvolvimento do País.

Art. $6^{\circ}$. Ao estrangeiro que pretende imigrar para o Brasil é facultado celebrar, ainda em seu país de origem, compromisso de compra e venda do imóvel rural desde que, dentro de 3 (três) anos, contados da data do contrato, venha fixar domicílio no Brasil e explorar o imóvel. 
$\S 1^{\circ}$ Se o compromissário comprador descumprir qualquer das condições estabelecidas neste artigo, reputar-se-á absolutamente ineficaz o compromisso de compra e venda, sendo-lhe defeso adquirir, por qualquer modo, a propriedade do imóvel.

$\S 2^{\circ}$ No caso previsto no parágrafo antecedente, caberá ao promitente-vendedor propor a ação para declarar a ineficácia do compromisso, estando desobrigado de restituir as importâncias que recebeu do compromissário comprador.

$\S 3^{\circ} \mathrm{O}$ prazo referido neste artigo poderá ser prorrogado pelo Ministério da Agricultura, ouvido o INCRA, se o promitente-comprador embora sem transferir seu domicílio para o Brasil por motivo justificado, utilizou o imóvel na implantação de projeto de culturas permanentes.

$\S 4^{\circ}$ Dos compromissos de compra e venda devem constar obrigatoriamente, sob pena de nulidade, as cláusulas estabelecidas neste artigo.

Art. $7^{\circ}$. À aquisição de imóvel rural por pessoa física estrangeira não poderá exceder a 50 (cinquenta) módulos de exploração indefinida, em área contínua ou descontínua.

$\S 1^{\circ}$ Quando se tratar de imóvel com área não superior a 3 (três) módulos, à aquisição será livre, independendo de qualquer autorização ou licença, ressalvadas as exigências gerais determinadas em lei.

$\S 2^{\circ}$ À aquisição de imóvel rural entre 3 (três) e 50 (cinqüenta) módulos de exploração indefinida dependerá de autorização do INCRA, ressalvado o disposto no artigo $2^{\circ}$.

$\S 3^{\circ}$ Dependerá também de autorização à aquisição de mais de um imóvel, com área não superior a três módulos, feita por uma pessoa física.

$\S 4^{\circ} \mathrm{A}$ autorização para aquisição por pessoa física condicionar-se-á, se o imóvel for de área superior a 20 (vinte) módulos, à aprovação do projeto de exploração correspondente.

$\S 5^{\circ}$ O Presidente da República, ouvido o Conselho de Segurança Nacional, poderá aumentar o limite fixado neste artigo.

Art. $8^{\circ}$. Nos loteamentos rurais efetuados por empresas particulares de colonização, à aquisição e ocupação de, no mínimo, 30\% (trinta por cento) da área total, serão feitas obrigatoriamente por brasileiros.

$\S 1^{\circ}$ A empresa colonizadora é responsável pelo encaminhamento dos processos referentes à aquisição do imóvel rural por estrangeiro, observadas as disposições da legislação vigente, até que seja lavrada a escritura pública.

$\S 2^{\circ}$ Semestralmente a empresa colonizadora deverá encaminhar, ao órgão estadual do INCRA, relação dos adquirentes, mencionando a percentagem atualizada das áreas rurais pertencentes a estrangeiros, no loteamento.

Art. $9^{\circ}$. O interessado que pretender obter autorização para adquirir imóvel rural formulará requerimento ao INCRA, declarando:

a) se possui, ou não, outros imóveis rurais;

b) se, com a novà aquisição, suas propriedades não excedem 50 (cinquenta) módulos de exploração indefinida, em área contínua ou descontínua;

c) a destinação a ser dada ao imóvel, através do projeto de exploração, se a área for superior a 20 (vinte) módulos.

Parágrafo único. O requerimento de autorização será instruído por documentos que provem: 1) a residência do interessado no território nacional; 2) a área total do município onde se situa o imóvel a ser adquirido; 3) a soma das áreas rurais transcritas em nome de estrangeiros, no município, por grupos de nacionalidade; 4) qualquer das circunstâncias mencionadas nos incisos do $\S 2^{\circ}$ do artigo $5^{\circ}$ deste Regulamento.

Art. 10. Concedida a autorização pelo INCRA, que ouvirá previamente a Secretaria Geral do Conselho de Segurança Nacional, quando for o caso, poderá o Tabelião lavrar a escritura, nela mencionando obrigatoriamente:

I - O documento de identidade do adquirente;

II - Prova de residência no território nacional;

III - A autorização do INCRA.

Parágrafo único. O prazo de validade da autorização é de 30 dias, dentro do qual deverá ser lavrada a escritura pública, seguindo-se a transcrição na Circunscrição Imobiliária, no prazo de 15 dias.

Art. 11. A pessoa jurídica estrangeira, autorizada a funcionar no Brasil, ou a pessoa jurídica brasileira, na hipótese do artigo $1^{\circ} \S 1^{\circ}$, só poderão adquirir imóveis rurais quando estes se destinem à implantação de projetos agrícolas pecuários, industriais, ou de colonização vinculados aos seus objetivos estatuários.

$\S 1^{\circ}$ À aquisição dependerá da aprovação dos projetos pelo Ministério da Agricultura, ouvido o órgão federal competente.

$\S 2^{\circ}$ São competentes para apreciar os projetos:

a) o INCRA, para os de colonização;

b) a SUDAM e a SUDENE, para os agrícolas e pecuários situados nas respectivas áreas; 
c) O Ministério da Indústria e do Comércio, para os industriais e turísticos, por intermédio do Conselho do Desenvolvimento Industrial e da Empresa Brasileira de Turismo, respectivamente.

Art. 12. A pessoa jurídica que pretender aprovação de projeto deverá apresentá-lo ao órgão competente, instruindo o pedido com documentos que provem:

a) a área total do município, onde se situa o imóvel a ser adquirido;

b) a soma das áreas rurais transcritas em nome de estrangeiros, no município, por grupos de nacionalidade;

c) o assentimento prévio da Secretaria Geral do Conselho de Segurança Nacional, no caso de o imóvel situar-se em área considerada indispensável à segurança nacional;

d) o arquivamento do contrato social ou estatuto no Registro de Comércio;

e) a adoção de forma nominativa de suas ações, feita por certidão do Registro de Comércio, nas hipóteses previstas no artigo 13 deste regulamento.

Parágrafo único. Observar-se-á o mesmo procedimento nos casos previstos no $\S 3^{\circ}$, do artigo $5^{\circ}$, deste regulamento, hipótese em que o projeto, depois da manifestação do Ministério da Agricultura, será encaminhado ao Presidente da República para decisão.

Art. 13. Adotarão obrigatoriamente a forma nominativa as ações de sociedades anônimas:

I - Que se dediquem a loteamento rural;

II - Que explorem diretamente áreas rurais;

III - Que sejam proprietárias de imóveis rurais não-vinculados a suas atividades estatutárias.

Parágrafo único. A norma deste artigo não se aplica às autarquias, empresas públicas e sociedades de economia mista, mencionadas, no artigo $4^{\circ}$ do Decreto-lei $\mathrm{n}^{\circ} 200$, de 25 de fevereiro de 1967, com a redação que foi dada pelo Decreto-lei no 900, de 29 de setembro de 1967.

Art. 14. Deferido o pedido, lavrar-se-á escritura pública, dela constando obrigatoriamente:

a) a aprovação pelo Ministério da Agricultura;

b) os documentos comprobatórios de sua constituição e de licença para seu funcionamento no Brasil;

c) a autorização do Presidente da República, nos casos previstos no $\S 3^{\circ}$ do artigo $5^{\circ}$, deste regulamento.

$\S 1^{\circ}$ No caso de o adquirente ser sociedade anônima brasileira, constará a prova de adoção da forma nominativa de suas ações.

$\S 2^{\circ} \mathrm{O}$ prazo de validade do deferimento do pedido é de 30 dias, dentro do qual deverá ser lavrada a escritura pública, seguindo-se a transcrição na Circunscrição Imobiliária, no prazo de 15 dias.

Art. 15. Os Cartórios de Registro de Imóveis manterão cadastro especial em livro auxiliar das aquisições de terras rurais por pessoas estrangeiras, físicas e jurídicas, no qual se mencionará:

I - o documento de identidade das partes contratantes ou dos respectivos atos de constituição, se pessoas jurídicas;

II - memorial descritivo do imóvel, com área, características, limites e confrontações;

III - a autorização do órgão competente, quando for o caso;

IV - as circunstâncias mencionadas no $\S 2^{\circ}$, do artigo $5^{\circ}$.

Parágrafo único. O livro (modelo anexo) terá páginas duplas, divididas em 5 colunas, com $3,5 \mathrm{~cm} 9,5 \mathrm{~cm}$, $14 \mathrm{~cm}, 12 \mathrm{~cm}$ e $15 \mathrm{~cm}$, encimadas com os dizeres " ${ }^{0 "}$ "Adquirente e Transmitente", "Descrição do Imóvel", "Certidões e Autorizações" e "Averbações" respectivamente, e nele registrar-se-ão as aquisições referidas neste regulamento, na data da transcrição do título.

Art. 16. Trimestralmente, os Cartórios de Registro de Imóveis remeterão, sob pena de perda de cargo, à Corregedoria da Justiça dos Estados a que estiverem subordinados e à repartição estadual do INCRA, relação das aquisições de áreas rurais por pessoas estrangeiras, da qual constem os dados enumerados no artigo anterior.

Parágrafo único. Quando se tratar de imóvel situado em área indispensável à segurança nacional, a relação mencionada neste artigo deverá ser remetida também à Secretaria Geral do Conselho de Segurança Nacional.

Art. 17. Para os efeitos da Lei número 4.504, de 30 de novembro de 1964 e deste regulamento, consideram-se empresas particulares de colonização as pessoas físicas nacionais ou estrangeiras, residentes ou domiciliadas no Brasil, ou jurídicas, constituídas e sediadas no País, que tiverem por finalidade executar programa de valorização de área ou distribuição de terras.

Art. 18. Salvo nos casos previstos em legislação de núcleos coloniais onde se estabeleçam em lotes rurais, como agricultores, estrangeiros imigrantes, é vedada, a qualquer título a doação de terras da União ou dos Estados a pessoas estrangeiras, físicas ou jurídicas.

Art. 19. É nula de pleno direito à aquisição de imóvel rural que viole as prescrições legais: o Tabelião que lavrará a escritura e o oficial de registro que a transcrever responderão civilmente pelos danos que causarem aos contratantes, sem prejuízo da responsabilidade criminal por prevaricação ou falsidade ideológica; o alienante ficará obrigado a restituir ao adquirente o preço do imóvel, ou as quantias recebidas a este título, como parte do pagamento. 
Art. 20. As normas regulamento aplicam-se a qualquer alienação de imóvel rural para pessoa física ou jurídica estrangeira, em casos como o de fusão ou incorporação de empresas, de alteração do controle acionário da sociedade, ou de transformação de pessoa jurídica nacional para pessoa jurídica estrangeira. Parágrafo único. O Oficial de Registro de Imóveis só fará a transcrição de documentos relativos aos negócios de que trata este artigo, se neles houver a reprodução das autorizações correspondentes.

Art. 21. Este Decreto entrará em vigor na data de sua publicação, revogadas as disposições em contrário. Brasília, 26 de novembro de $1974 ; 153^{\circ}$ da Independência e $86^{\circ}$ da República.

ERNESTO GEISEL, Armando Falcão, Alysson Paulinelli, Savero Fagundes Gomes (DOU, 27/11/1974)

LEI No 11.949, DE 17 DE JUNHO DE 2009.

(Conversão da Medida Provisória $n^{\circ}$ 454, de 2009 - Dá nova redação à Lei nº 10.304, de 5 de novembro de 2001, que transfere ao domínio dos Estados de Roraima e do Amapá as terras pertencentes à União e dá outras providências.)

O VICE-PRESIDENTE DA REPÚBLICA, no exercício do cargo de PRESIDENTE DA REPÚBLICA Faço saber que o Congresso Nacional decreta e eu sanciono a seguinte Lei:

Art. $1^{\circ}$ Os arts. $1^{\circ}, 2^{\circ}, 3^{\circ}$ e $4^{\circ}$ da Lei $\mathrm{n}^{\circ} 10.304$, de 5 de novembro de 2001 , passam a vigorar com a seguinte redação:

“Art. $1^{\circ}$ As terras pertencentes à União compreendidas nos Estados de Roraima e do Amapá passam ao domínio desses Estados, mantidos os seus atuais limites e confrontações, nos termos do art. 14 do Ato das Disposições Constitucionais Transitórias." (NR)

"Art. $2^{\circ}$ São excluídas da transferência de que trata esta Lei:

I - as áreas relacionadas nos incisos II a XI do art. 20 da Constituição Federal;

II - as terras destinadas ou em processo de destinação pela União a projetos de assentamento;

III - as áreas de unidades de conservação já instituídas pela União e aquelas em processo de instituição, conforme regulamento;

IV - as áreas afetadas, de modo expresso ou tácito, a uso público comum ou especial;

$\mathrm{V}$ - as áreas destinadas a uso especial do Ministério da Defesa; e

VI - as áreas objeto de títulos expedidos pela União que não tenham sido extintos por descumprimento de cláusula resolutória." (NR)

“Art. $3^{\circ}$ As terras transferidas ao domínio dos Estados de Roraima e do Amapá deverão ser preferencialmente utilizadas em atividades agrícolas diversificadas, de conservação ambiental e desenvolvimento sustentável, de assentamento, de colonização e de regularização fundiária, podendo ser adotado o regime de concessão de uso previsto no Decreto-Lei no 271, de 28 de fevereiro de 1967. , (NR)

“Art. $4^{\circ}$ O Poder Executivo regulamentará esta Lei." (NR)

Art. $2^{\circ}$ Dê-se à ementa da Lei $\mathrm{n}^{\circ} 10.304$, de 5 de novembro de 2001 , a seguinte redação:

“Transfere ao domínio dos Estados de Roraima e do Amapá terras pertencentes à União e dá outras providências."

Art. $3^{\circ}$ Esta Lei entra em vigor na data de sua publicação.

Brasília, 17 de junho de 2009; $188^{\circ}$ da Independência e 121ํㅡㄹ da República.

JOSÉ ALENCAR GOMES DA SILVA e Guilherme Cassel 